\title{
Timing and Duration of Flow in Ephemeral Streams of the Sierra Vista Subwatershed of the Upper San Pedro Basin, Cochise County, Southeastern Arizona
}
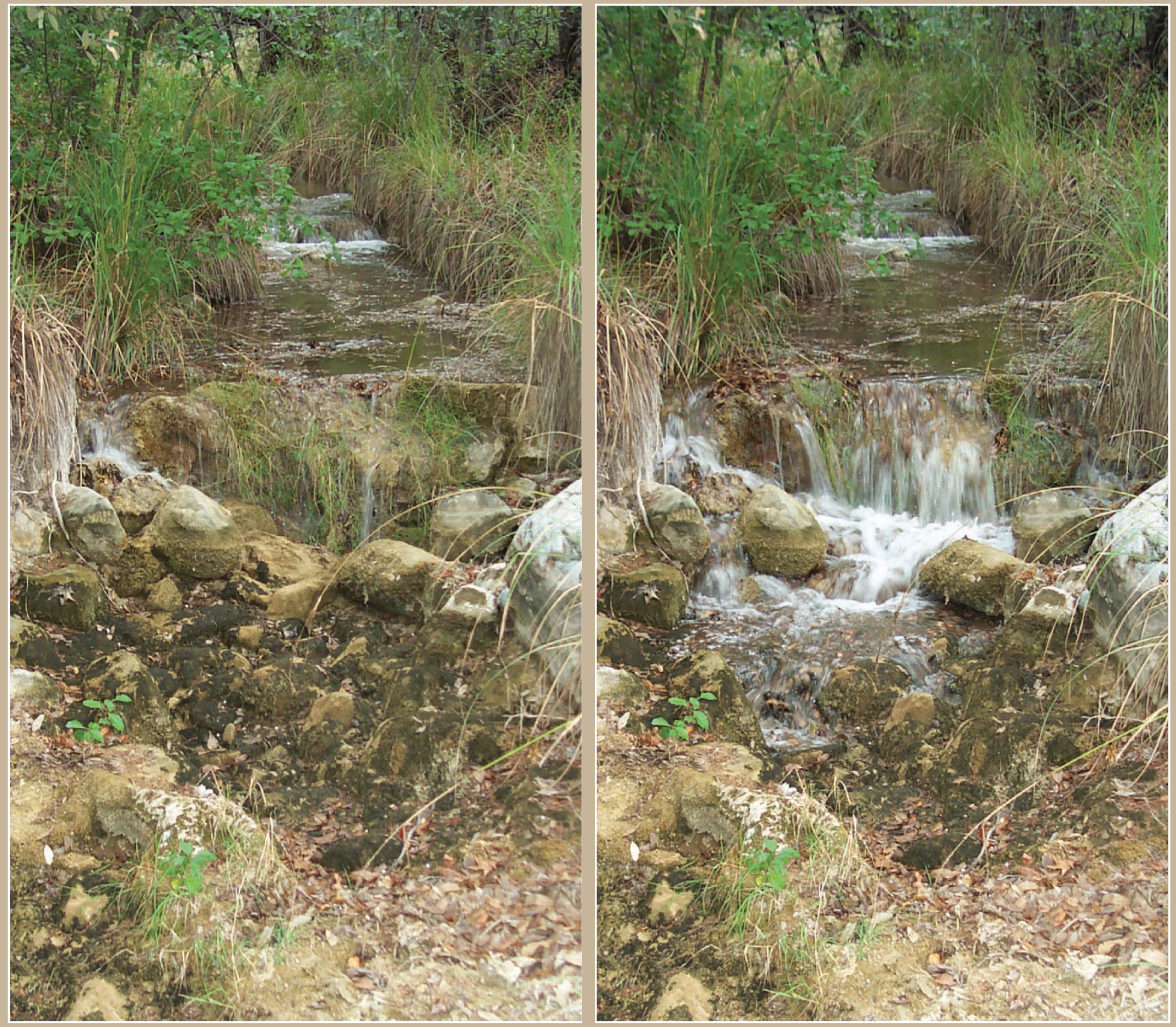

Scientific Investigations Report 2005-5190 
Inside Front Cover BLANK 


\section{Timing and Duration of Flow in Ephemeral Streams of the Sierra Vista Subwatershed of the Upper San Pedro Basin, Cochise County, Southeastern Arizona}

By Bruce Gungle

Prepared in cooperation with the

BUREAU OF LAND MANAGEMENT

Scientific Investigations Report 2005-5190 


\section{U.S. Department of the Interior \\ Gale A. Norton, Secretary \\ U.S. Geological Survey \\ P. Patrick Leahy, Acting Director}

\section{U.S. Geological Survey, Reston, Virginia: 2006}

For product and ordering information:

World Wide Web: http://www.usgs.gov/pubprod

Telephone: 1-888-ASK-USGS

For more information on the USGS — the Federal source for science about the Earth, its natural and living resources, natural hazards, and the environment:

World Wide Web: http://www.usgs.gov

Telephone: 1-888-ASK-USGS

Any use of trade, product, or firm names is for descriptive purposes only and does not imply endorsement by the U.S. Government.

Although this report is in the public domain, permission must be secured from the individual copyright owners to reproduce any copyrighted materials contained within this report.

Suggested citation:

Gungle, Bruce, 2006, Timing and duration of flow in ephemeral streams of the Sierra Vista Subwatershed of the Upper San Pedro Basin, Cochise County, southeastern Arizona: U.S. Geological Survey Scientific Investigations Report 2005-5190, 47 p.

V. 2, revised February, 27, 2007. 


\section{Contents}

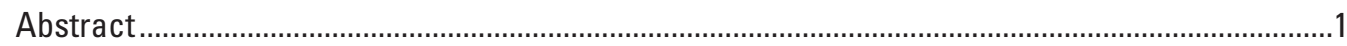

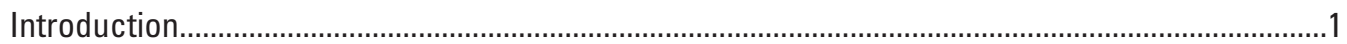

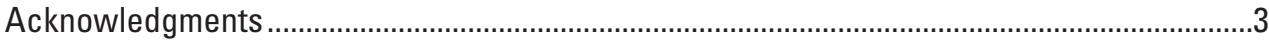

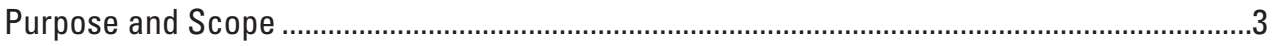

Description of the Study Area …...........................................................................................

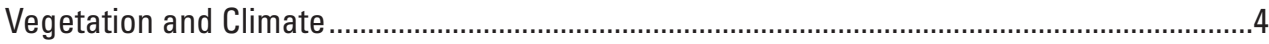

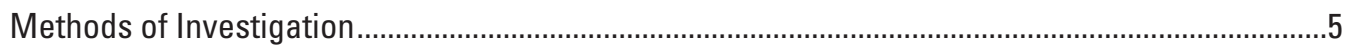

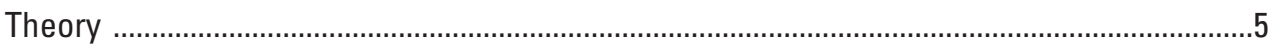

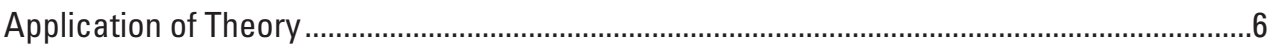

Installation of Temperature Loggers...................................................................................

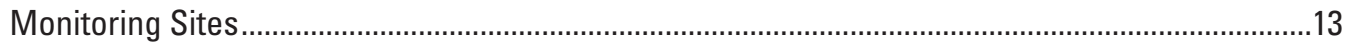

Precipitation Patterns During the Monitoring Period .......................................................................14

Timing and Duration of Flow in Ephemeral Streams .........................................................................14

Spatial Streamflow Patterns ................................................................................................. 14

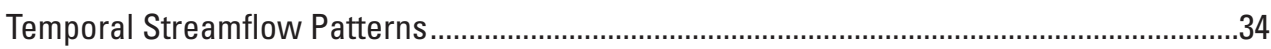

Frequency of Streamflow in Three Representative Channels ................................................35

Garden Canyon Wash ........................................................................................................36

Ramsey Canyon Wash ..................................................................................................

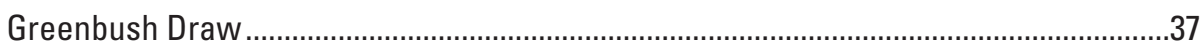

Variability of Streamflow in Three Representative Channels..............................................38

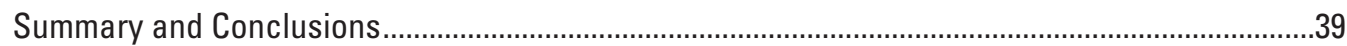

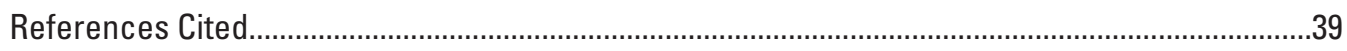

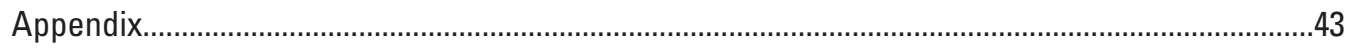




\section{Figures}

1. Map showing locations of the study area, drainage basins, temperature loggers, streamflow-gaging stations, precipitation gages, and stage recorder in the Sierra Vista Subwatershed of the Upper San Pedro Basin, Arizona.

2. Graphs showing precipitation at three stations in the Sierra Vista Subwatershed, Arizona, 2000, 2001, and 2002

3. Stratigraphic column of geologic units in the Sierra Vista Subwatershed, Arizona

4. Thermograph and streamflow record from Greenbush Draw, Sierra Vista Subwatershed, Arizona

5. Photograph showing temperature-method calibration site, Greenbush Draw at State Route 92.

6. Graph showing sensitivity of temperature loggers to streamflow at three depths, Greenbush Draw at State Route 92

7. Original and adjusted natural log fits for $\Delta \mathrm{T}_{\text {crit }}$ versus standard deviation of temperature from Greenbush Draw at State Route 92, monsoon 2003, for logger burial depths of $10,15,20,25,30$, and 35 centimeters below streambed surface

8. Photograph showing typical field deployment of temperature logger in a polyvinyl chloride housing tethered to a small tree trunk with airplane cable 13

9-16. Maps showing:

9. Duration of ephemeral streamflow at temperature-logger sites in the Sierra Vista Subwatershed, Arizona, west side, for the entire period of study, December 1, 2000, to May 31, 2002

10. Duration of ephemeral streamflow at temperature-logger sites and at selected streamflow-gaging stations in the Sierra Vista Subwatershed, Arizona, east side, for the entire period of study, December 1, 2000, to May 31, 2002

11. Duration of ephemeral streamflow at temperature-logger sites in the Sierra Vista Subwatershed, Arizona, west side, 2000-2001 nonmonsoon (December 1, 2000, to May 31, 2001)

12. Duration of ephemeral streamflow at temperature-logger sites and at selected streamflow-gaging stations in the Sierra Vista Subwatershed, Arizona, east side, 2000-2001 nonmonsoon (December 1, 2000, to May 31, 2001)

13. Duration of ephemeral streamflow at temperature-logger sites in the Sierra Vista Subwatershed, Arizona, west side, 2001 monsoon (June 1, 2001, to September 19, 2001).

14. Duration of ephemeral streamflow at temperature-logger sites and at selected streamflow-gaging stations in the Sierra Vista Subwatershed, Arizona, east side, 2001 monsoon (June 1, 2001, to September 19, 2001)...

15. Duration of ephemeral streamflow at temperature-logger sites in the Sierra Vista Subwatershed, Arizona, west side, 2001-2002 nonmonsoon (September 20, 2001, to May 31, 2002)

16. Duration of ephemeral streamflow at temperature-logger sites and at selected streamflow-gaging stations in the Sierra Vista Subwatershed, Arizona, east side, 2001-2002 nonmonsoon (September 20, 2001, to May 31, 20002. 


\section{Figures-Continued}

17-21. Graphs showing:

17. Total normalized streamflow duration, mean streamflow duration, and normalized number of streamflows, Sierra Vista Subwatershed, Arizona, west side, for all periods of the study.

18. Total normalized streamflow duration, mean streamflow duration, and normalized number of streamflows, Sierra Vista Subwatershed, Arizona, east side, for all periods of the study. 33

19. Comparison of normalized rural and urban streamflows in the Sierra Vista Subwatershed, Arizona, during 2000-2001 nonmonsoon, 2001 monsoon, and 2001-2002 nonmonsoon

20. Comparison of all normalized streamflows across the Sierra Vista Subwatershed, Arizona, by period. 35

21. Comparison of normalized streamflows in the Sierra Vista Subwatershed, Arizona, west side and east side, by period 35

\section{Tables}

1. Temperature-logger streamflow detection compared to streamflow detection at Greenbush Draw gaging station for the period June 1, 2002, to September 19, 2002

2. Approximate distances between ephemeral-stream monitoring sites and mountain fronts.

3. Dates and times of streamflows in Garden Canyon, December 1, 2000, to May 31, 2002

4. Dates and times of streamflows in Ramsey Canyon, December 1, 2000, to May 31,2002 .37

5. Dates and times of streamflows in Greenbush Draw, December 1, 2000, to May 31, 2002 


\section{Conversion Factors and Datums}

\begin{tabular}{lll}
\hline \multicolumn{1}{c}{ Multiply } & \multicolumn{1}{c}{ By } & \multicolumn{1}{c}{ To obtain } \\
\hline centimeter $(\mathrm{cm})$ & 0.3937 & inch (in.) \\
meter $(\mathrm{m})$ & 3.281 & foot $(\mathrm{ft})$ \\
kilometer $(\mathrm{km})$ & 0.6214 & mile (mi) \\
square kilometer $\left(\mathrm{km}^{2}\right)$ & 0.3861 & square mile $\left(\mathrm{mi}^{2}\right)$ \\
\hline
\end{tabular}

Temperature in degrees Celsius $\left({ }^{\circ} \mathrm{C}\right)$ may be converted to degrees Fahrenheit $\left({ }^{\circ} \mathrm{F}\right)$ as follows:

$$
{ }^{\circ} \mathrm{F}=\left(1.8 x^{\circ} \mathrm{C}\right)+32
$$

Vertical coordinate information is referenced to the National Geodetic Vertical Datum of 1929 (NGVD 29).

Horizontal coordinate information is referenced to the North American Datum of 1927 (NAD 27). Altitude, as used in this report, refers to distance above the vertical datum. 


\title{
Timing and Duration of Flow in Ephemeral Streams of the Sierra Vista Subwatershed of the Upper San Pedro Basin, Cochise County, Southeastern Arizona
}

\author{
By Bruce Gungle
}

\section{Abstract}

Frequency, timing, and duration of streamflow were monitored in 20 ephemeral-stream channels across the Sierra Vista Subwatershed of the Upper San Pedro Basin, southeastern Arizona, during an 18-month period. One channel (Walnut Gulch) had Agricultural Research Service streamflow-gaging stations in place. The sediments of the remaining 19 ephemeral-stream channels were instrumented with multiple temperature loggers along the channel lengths. A hermograph-interpretation technique was developed in order to determine frequency, timing, and duration of streamflow in these channels. Streamflow onset was characterized by exceedance of a critical minimum drop in temperature within the channel sediments during any 15 -minute interval, whereas streamflow cessation was identified by the local temperature minimum that immediately followed the critical temperature drop. All data for the 18-month period from December 1, 2000, to May 31, 2002, were analyzed in terms of monsoon (June 1 to September 19) and nonmonsoon (September 20 to May 31) periods. Nonmonsoon precipitation during the 2000-2002 study period (excludes October and November 2000) was 82 percent and 39 percent of the 30-year average, respectively, whereas monsoon precipitation during 2001 was 99 percent of the 30-year average. Ephemeral streamflow was detected at least once during the monitoring period at 87 percent of the monitoring sites ( 45 of the 52 sites that returned useful data; includes 4 streamflow-gaging stations). The summer monsoon period accounted for 82 percent of all streamflow events by number and 71 percent of all events by total streamflow duration. Nonmonsoon streamflow events peaked in number, total streamflow duration, and mean streamflow duration midway between the Huachuca Mountains and the San Pedro River on the west side of the subwatershed. These three streamflow parameters dropped off sharply about 10 kilometers from the mountain front. The number and total duration of nonmonsoon streamflows on the east side of the subwatershed trended downward with increased distance from the mountain fronts. Monsoon streamflow events were more evenly distributed across the subwatershed than nonmonsoon events, and the number and duration of streamflows generally trended upward with distance from the mountain fronts. Additional years of data are needed to determine whether these patterns are consistent year to year, or were due to randomness in the spatial distribution of precipitation. Streamflows in three ephemeral-stream channels were analyzed in detail. More than two-thirds of the streamflow events detected in each of these channels occurred at no more than one monitoring site along the channel length. In only one of the three channels-Garden Canyon - was a streamflow event detected at all logger sites along its length. Five temperature loggers provided data from urbanized areas, and these loggers detected streamflow more than 50 percent more often and of a duration nearly three times greater than did temperature loggers across the rural parts of the subwatershed. Because historical records do not indicate that more precipitation occurs in the urbanized area than in the rural areas, the increased frequency of flow detection in the urban area is attributed to an increase in runoff from the impervious surfaces throughout the urbanized area.

\section{Introduction}

To better define recharge distributions in the Sierra Vista Subwatershed of the Upper San Pedro Basin in southeastern Arizona (fig. 1), an investigation of ephemeral-stream channel flow was begun by the U.S. Geological Survey (USGS), in cooperation with the Bureau of Land Management. This investigation was to partly address water-resource concerns identified by the Upper San Pedro Partnership. The partnership comprises 20 agencies and organizations that are working together to meet the water needs of the people living in the Upper San Pedro Basin while protecting the San Pedro River. 


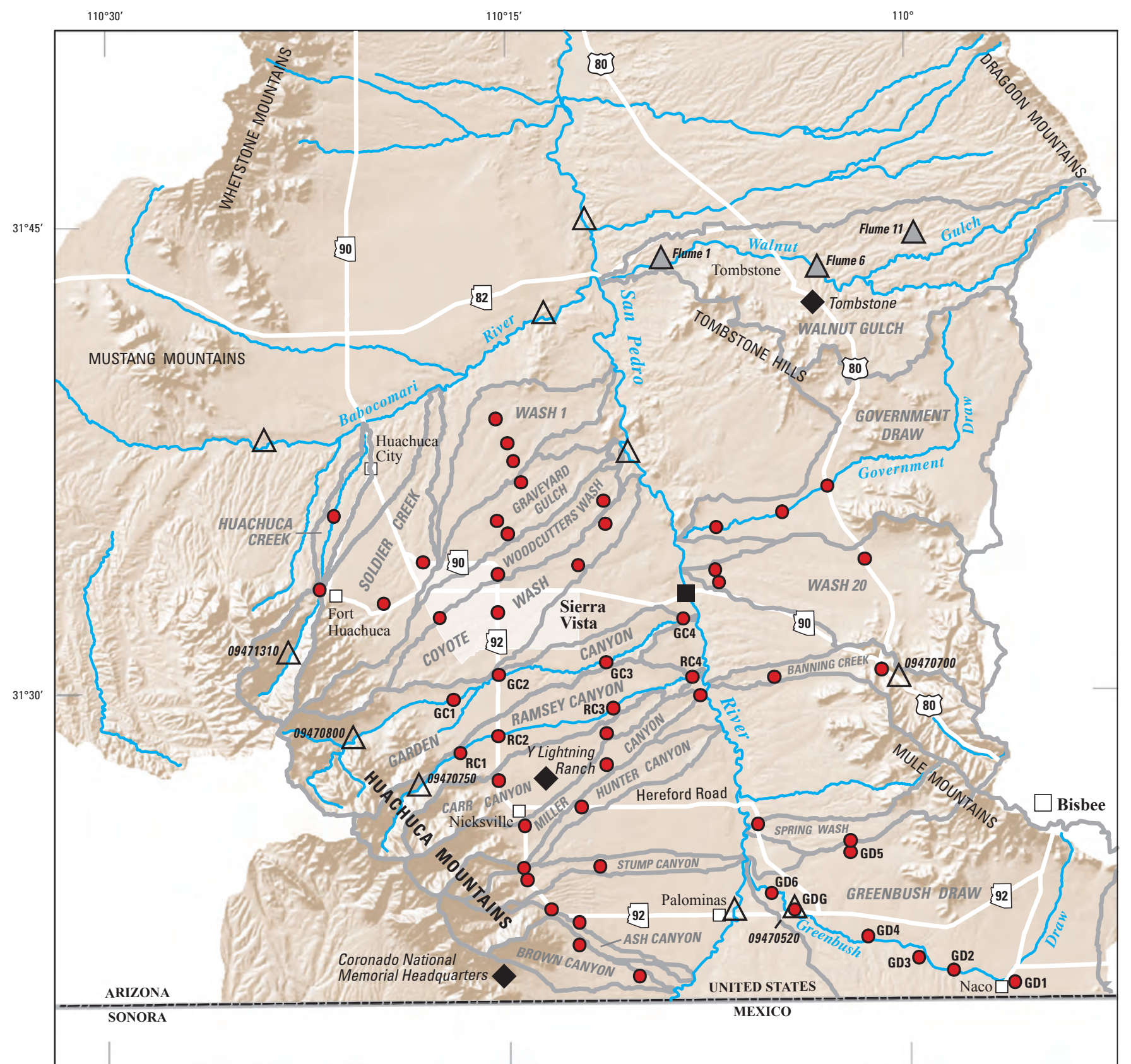

Base from U.S. Geological Survey digital elevation model data,

Universal Transverse Mercator

Projection, Zone 12. Datum: NAD 27

\section{EXPLANATION}

\begin{tabular}{cl}
\hline DRAINAGE BASIN BOUNDARY \\
TEMPERATURE LOGGER \\
Flume 11 $\triangle \quad \begin{array}{c}\text { STREAMFLOW-GAGING STATION- } \\
\text { U.S. Geological Survey }\end{array}$ \\
$\begin{array}{c}\text { STREAMFLOW-GAgING STATION- } \\
\text { Agricultural Research Service }\end{array}$
\end{tabular}
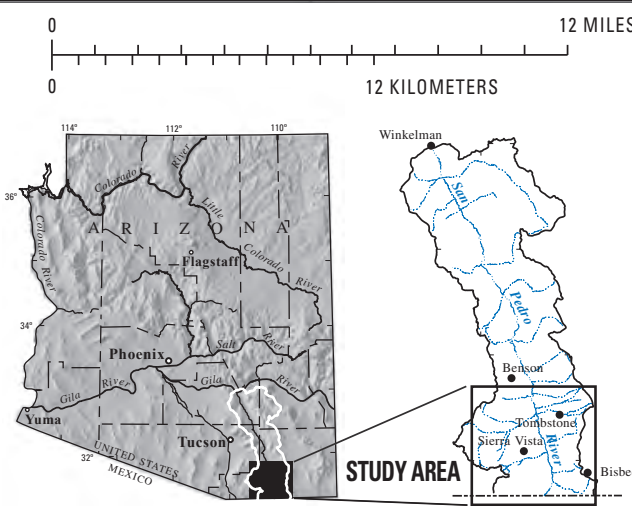

Figure 1. Locations of the study area, drainage basins, temperature loggers, streamflow-gaging stations, precipitation gages, and stage recorder in the Sierra Vista Subwatershed of the Upper San Pedro Basin, Arizona. 
Streamflow duration is one of many parameters that influence streamflow infiltration and recharge in ephemeralstream channels. This investigation primarily used temperature loggers buried in the sediments of stream channels to provide data that would indicate the onset, duration, cessation, and location of flow in ephemeral-stream channels across the Sierra Vista Subwatershed. Comparisons of normalized streamflow data then determined the primary locations of streamflow and recharge across the subwatershed.

\section{Acknowledgments}

The temperature-logger network was conceived of and initiated by Alissa Coes and Don Pool of the USGS who have also provided constructive feedback on the thermographinterpretation techniques. Discussions with Kyle Blasch, USGS, regarding thermograph interpretation and statistical analyses of thermographs were also beneficial. The author would like to thank Jack Ladd of Ladd Ranch and Tom Cox of Cox Ranch for permission to install temperature loggers on their respective properties, and the staff at Coronado National Memorial, National Park Service, for its support of a temperature-logger site within the boundaries of the memorial.

\section{Purpose and Scope}

This report provides the time and estimated duration of streamflow for the 18 months from December 1, 2000, through May 31, 2002, for 20 ephemeral-stream channels in the Sierra Vista Subwatershed of the Upper San Pedro Basin. With the exception of two stream channels, ephemeral streamflow was estimated using a subsurface-temperature method. Streamflow-gaging stations were used for three sites on Walnut Gulch. On Greenbush Draw one gaging station was used in addition to four temperature-logger sites.

The monitored drainages extended from Greenbush Draw in the south, $1 \mathrm{~km}$ north of the international boundary with Mexico, to Walnut Gulch near Tombstone in the north, about $45 \mathrm{~km}$ north of the international boundary. Temperature loggers were installed in 20 channels from the eastern foot of the Huachuca Mountains on the west side of the subwatershed, to the western foot of the Mule Mountains on the east side (fig. 1). At least two temperature loggers were installed in each of the channels. Fourteen of the channels are west of the San Pedro River, originating in either the Huachuca Mountains or the alluvial surface above the river. The remaining six tributary channels are on the east side of the subwatershed and originate in the south or west side of the Mule Mountains, the Tombstone Hills, or the southern part of the Dragoon Mountains.

\section{Description of the Study Area}

Elevations across the Sierra Vista Subwatershed range from 1,163 m at the State Route 82 crossing of the San Pedro River at Fairbank to 2,879 $\mathrm{m}$ at Miller Peak in the Huachuca Mountains. The subwatershed is bounded on the west by the
Huachuca Mountains (about 1,500 to 2,900 m altitude) and the Mustang Mountains (about 1,200 to 2,000 m altitude) and on the east by the Mule Mountains, the Tombstone Hills, and the southern end of the Dragoon Mountains (about 1,500 to 2,250 $\mathrm{m}$ altitude). Much of the subwatershed from the river terraces to the foot of the mountains lies between 1,200 and 1,500 $\mathrm{m}$ altitude. The subwatershed is drained by the San Pedro River, an intermittent stream that enters the subwatershed at the international boundary with Mexico and exits about $45 \mathrm{~km}$ to the north near State Route 82 (fig. 1). With the exception of the intermittent Babocomari River near the northern (downstream) boundary of the subwatershed, all the tributary streams across the floor of the subwatershed are ephemeral.

Tributary streams along the west side of the subwatershed generally flow east-northeastwardly, from the northeast-facing Huachuca Mountains to the San Pedro River. Tributaries draining the mountains on the east side of the subwatershed trend westward, or west-northwestward. Greenbush Draw, the major southern tributary, drains the southern extent of the Mule Mountains and the north side of Sierra San Jose, in Mexico, then turns northwestward and joins the San Pedro River north of Palominas. Two channels included in the study (Soldier Creek and Huachuca Canyon) are tributaries of the Babocomari River (fig. 1).

Predevelopment water-table altitudes across the Sierra Vista Subwatershed varied as a function of distance from the mountain fronts and the San Pedro River. Correll and others' (1996; in Arizona Department of Water Resources, 2005) 1940 ground-water altitude map, which represents predevelopment conditions, shows water levels dropping off steeply eastward from the eastern edge of the Huachuca Mountains, where the regional aquifer is thin, toward the San Pedro River, where the aquifer is thicker. Although water levels across much of the subwatershed have fallen since 1940, particularly near urbanized areas, water levels near the mountain fronts and along the San Pedro River have remained largely unchanged (Arizona Department of Water Resources, 2005).

Urbanized areas on the west side of the Sierra Vista Subwatershed include the city of Sierra Vista and nearby Fort Huachuca at the foot of the Huachuca Mountains, and the town of Huachuca City north of the fort on the Babocomari River drainage. Residential development has been rapid in an unincorporated area southeast of Sierra Vista, from State Route 92 to the San Pedro River, for at least the last 10 yr, but the development generally is low in density and includes little infrastructure such as sewer lines, paved streets, or a large water distribution system (U.S. Census Bureau, 2004). At the northeastern end of the subwatershed is the city of Tombstone in the Tombstone Hills, and at the southeastern end is the city of Bisbee in the Mule Mountains. The unincorporated border community of Naco, about $12 \mathrm{~km}$ south of Bisbee, sits adjacent to Greenbush Draw (fig. 1). 


\section{Vegetation and Climate}

Vegetation across the Sierra Vista Subwatershed includes cottonwood-willow galleries and velvet mesquite bosques close to the San Pedro and Babocomari Rivers, tamarisk in places along the San Pedro River, scattered to dense mesquite along the river terraces and in the ephemeral tributaries, and grasslands and desert scrub across much of the basin floor. Oak woodlands occur on the lower mountain slopes and grade into pinyon-juniper forests with increasing altitude. Mixed conifer forests occur at higher altitudes on the basin perimeter (Hereford, 1993; U.S. Environmental Protection Agency, 2005).

Precipitation generally is a function of altitude across the subwatershed, with greater amounts occurring at the higher elevations. The Huachuca Mountains receive the most precipitation in the Upper San Pedro Basin (Pool and Coes, 1999). Annual precipitation in the basin is bimodal, with about half coming in the summer rainy season, June through September (the North American monsoon). About a third of the nonmonsoon precipitation occurs during the winter months from November to February (fig. 2).

Summer monsoon precipitation is produced principally by air mass thunderstorms with a dominant moisture source in the tropical eastern Pacific Ocean and the Gulf of California (Adams and Comrie, 1999). As a result, summer rainfall events are commonly intense and highly localized: $2 \mathrm{~cm}$ of rain falling within 30 min can be expected every $2 \mathrm{yr}$, as can $3 \mathrm{~cm}$ of rain falling within $60 \mathrm{~min}$ (Dunne and Leopold, 1978). Such events would be expected to generate similarly intense, flashy streamflows in ephemeral-stream channels. Winter rains are more typically broad-scale stratiform events, although convective showers, generally of lower intensity than summer thunderstorms, are not uncommon. Winter storms originate in the Pacific Ocean from the subtropics in the south to the Gulf of Alaska in the north, although the southern source is more common during El Niño years. In general, winter rains are more likely to soak into the ground than to run off in flashy discharge events.

Annual precipitation across the subwatershed averaged $41.4 \mathrm{~cm}$ from 1956 to 2002 on the basis of data from three stations: Coronado National Memorial Headquarters (southwestern part of subwatershed in Huachuca Mountains, 1,598 m altitude), Tombstone (northeastern part of subwatershed, 1,405 m altitude), and Y Lightning Ranch (west side of subwatershed, 1,399 m altitude; fig. 1). Only the Tombstone record extends back into the 19th century; precipitation at the Tombstone station averaged $35.1 \mathrm{~cm}$ from 1897 to 2002 . The slight decreasing trend in summer precipitation at Tombstone during this period is not statistically significant $(\mathrm{p}=0.12)^{1}$. Winter and spring precipitation showed variability but no overall trend

\footnotetext{
${ }^{1}$ The p-value indicates the likelihood that a value will occur at random given a normal distribution of random samples from the parent population. Statistical significance in this case was set at $\mathrm{p}<0.05$.
}
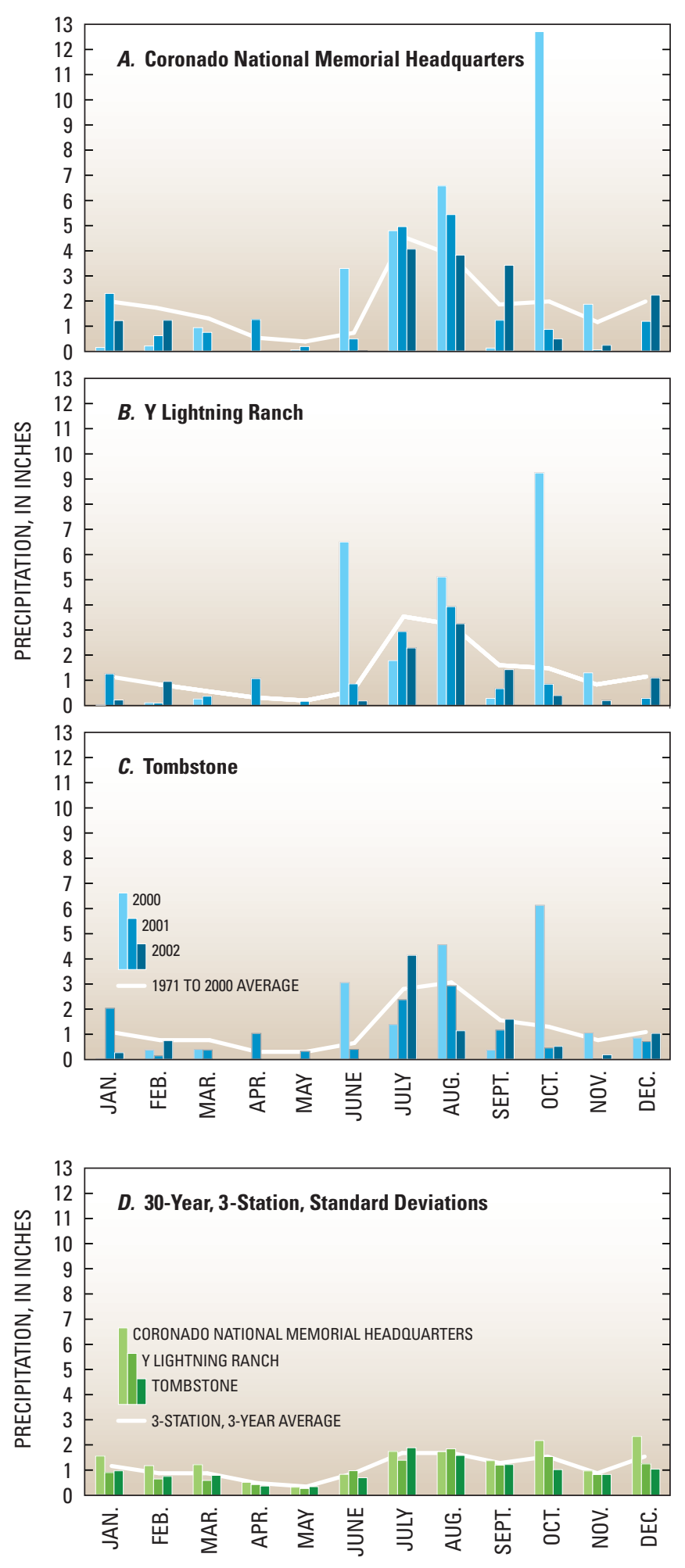

Figure 2. Monthly precipitation at three stations in the Sierra Vista Subwatershed, Arizona, 2000, 2001, and 2002. A, Coronado National Memorial Headquarters; $B$, Tombstone; $C$, Y Lightning Ranch; $D, 30$-year standard deviations for the three stations. 
at Tombstone from 1897 to 2002, including below average amounts during the mid-century drought (mid-1940s to the mid-1970s).

Precipitation during October does not fit into either the monsoon or winter-spring precipitation periods, and is variable (fig. 2D). In some years, significant precipitation can occur in October when troughs traversing the region from west to east draw tropical storms into the region. In other years October can be dry. On the basis of the Tombstone record, October precipitation may have an increasing trend, although this trend also lacks statistical significance $(\mathrm{p}=0.051)$.

\section{Methods of Investigation}

\section{Theory}

The energy exchanged between objects due to a difference in temperature is defined as heat (Serway, 1996). Conduction (kinetic energy transfer at the molecular level in non-moving solids and fluids) in a deep, uniform solid was first described by Carslaw and Jaeger (1959), and can be found in a number of more recent texts [for example, Jury and others (1991) and Hillel (1998)]. In a dry stream channel, heat moves downward into the sediments by conduction during the day. At night, radiational cooling at the surface reverses the direction of conductive heat flow, and the result is a quasisinusoidal temperature waveform at and just below the surface, and is approximated by

$$
T(z, t)=T_{a v e}+A_{o} e^{(-z / D)}[\sin (\omega t-z / D)],
$$

where

$$
\begin{aligned}
T= & \text { the temperature }\left({ }^{\circ} \mathrm{C}\right) \text { at depth } z(\mathrm{~m}) \text { and } \mathrm{t}(\mathrm{s}), \\
T_{\text {ave }}= & \text { the average temperature of the sediments } \\
& \text { (assumed same for all depths), } \\
A_{o}= & \text { the amplitude of the thermal wave at the } \\
& \text { surface }\left({ }^{\circ} \mathrm{C}\right), \text { and }
\end{aligned}
$$

The damping depth is related to the thermal properties of the soil and the frequency of the temperature fluctuations. At the damping depth, the thermal wave amplitude has decreased to $1 / e$ of the surface amplitude, or approximately 0.37 times. The term in brackets is the phase shift term where $\omega$ is the radial frequency (in radians); the phase shift at a given depth will be equivalent to the travel time of the temperature peak to that depth. For diurnal forcing where the period is one day,

$$
\omega=2 \pi(1 / 86,400 s)=7.27 x 10^{-5} / s .
$$

The term preceding the brackets in equation 1 describes the amplitude of the thermal wave at depth:

$$
A_{z}=A_{o} e^{(-z / D)},
$$

where

$A_{\mathrm{z}}=$ the amplitude of the thermal wave $\left({ }^{\circ} \mathrm{C}\right)$ at depth $z$. The presence of $-z$ in the numerator of the exponential term in equations 1 and 3 indicates that the amplitude of the temperature wave decreases with increasing depth.

The maximum rate of temperature change by conduction at depth $z$ will occur at the time of the inflection point of the thermal wave $\left(t_{i p}\right)$, which can be found by setting the second derivative of equation 1 equal to 0 :

$$
d^{2} T / d r^{2}=-\omega A_{o} e^{(z / D)} \cdot \sin (\omega t-z / D)=0,
$$

which becomes

$$
\sin (\omega-z / D)=0
$$

or

$$
\begin{gathered}
\omega t-z / D=\pi, \\
\omega t-z / D=2 \pi .
\end{gathered}
$$

Solving for $t$ in the case where temperature is decreasing (equation 6a) gives

$$
t_{i p}=(\pi+z / D) \omega^{-1} .
$$

The typical interval for ephemeral-streamflow temperature logging is either 15 or $30 \mathrm{~min}$. The largest decrease in temperature over a 15-min logging interval can thus be found by inserting $t_{i p}-7.5 \mathrm{~min}$ and $t_{i p}+7.5 \mathrm{~min}$ into equation 1 for $t$, solving for $T$ in each case, and taking the difference.

At the advent of streamflow in an ephemeral-stream channel, advection dominates the heat transport process. The temperature peak moving down through the sediment is described by Taniguchi and Sharma (1990):

$$
V_{T}=V_{w} \theta C_{w} / C_{s}
$$

where

$V_{T}=$ the velocity of the temperature peak,

$V_{w}=$ the mean macroscopic water velocity,

$\theta=$ the volume fraction of water (volume of water per bulk volume, including water),

$C_{w}=$ the volumetric heat capacity of water, and

$C_{s}=$ the volumetric heat capacity of the bulk sediment (including water). 
In cases where streamflow continues for several days, conduction again becomes significant (Constantz, Tyler, and Kwicklis, 2003), and both advection and conduction must be taken into account. In addition, the specific heat capacity of water is several times greater than that of dry sediments, and the heat capacity of the bulk sediment thus rises (linearly) with increasing water content. As a result, the amplitude of the diurnal temperature signal will be damped during periods of multiday streamflow.

\section{Application of Theory}

Rorabaugh (1954) first proposed the use of temperature methods as a means for estimating stream loss. At that time, such measurements were impractical owing to equipment limitations. Development of inexpensive temperature probes coupled with the wide availability of computer data storage and increased computational power have since made it possible to put these theoretical concepts into practice (Constantz and Stonestrom, 2003). In addition to determination of streamflow timing and duration-the primary focus of this report-temperature methods have been used since the late 1980s to characterize surface water/ground water interactions and streambed infiltration rates in Massachusetts, New Jersey, Arizona, Indiana, Nevada, Colorado, California, New Mexico, and Washington (Lapham, 1989; Jaynes, 1990; Silliman and Booth, 1993; Constantz and others, 1994; Constantz, 1998; Ronan and others, 1998; Allander, 2003; Bartolino, 2003; Conlon and others, 2003; Constantz, Cox, and others, 2003; Hoffmann and others, 2003); to estimate depth, duration, timing, and rates of percolation in ephemeral streams in New Mexico, California, Nevada, and Arizona (Constantz and Thomas, 1996; Constantz and others, 2002; Constantz, Tyler, and Kwicklis, 2003); to estimate seepage losses into alluvium from an intermittent stream in Nevada (Prudic and others, 2003); and to estimate streamflow beneath an ephemeral stream in Nevada (Ronan and others, 1998).

Constantz and Thomas $(1996,1997)$ and Constantz and others (2001) were the first to use temperature methods to document streamflow timing in intermittent- and ephemeralstream channels. Visual inspection of thermographs revealed series of days in which the amplitude of the temperature signal was damped; these periods were interpreted as having streamflow (Constantz and others, 2001). Prudic and others (2003) used a similar method to estimate the onset of streamflow on an intermittent creek in northern Nevada, as did Stewart (2003) in two ephemeral-stream channels in New Mexico and a third in Nevada.

Blasch and others (2004) used a moving standarddeviation window method to estimate the onset and cessation of streamflow in Rillito Creek in Tucson, Arizona. Points at which the standard deviation increased beyond some threshold value were interpreted as depicting the onset and cessation of streamflow. Five parameters were required to design a moving standard-deviation filter that minimized false negatives and false positives. Blasch and others (2004) note that near the surface the conductive thermal amplitude is larger than the advective thermal amplitude, whereas at depth the converse is true. They conclude that under some conditions, deeper (0.75-1.00 m) temperature measurements may be optimal for estimating streamflow timing. Lawler (2002) used the method of Blasch and others to evaluate the extent of perennial, intermittent, and ephemeral reaches of the San Pedro River.

Spatial and temporal patterns of ephemeral streamflow in tributary streams of the San Pedro River in the Sierra Vista Subwatershed are variable: flow duration in these streams rarely exceeds $24 \mathrm{~h}$ and can be as brief as $15 \mathrm{~min}$ (or less). Channel widths range from less than a meter to about $12 \mathrm{~m}$. Surface sediments in the stream channels include recent fluvial deposits and (or) Pleistocene-Holocene terrace deposits that vary from fine- to coarse-grained alluvium to gravels and cobbles, and range in depth from zero to at least $10 \mathrm{~m}$ (James Callegary, hydrologist, U.S. Geological Survey, written commun., 2005). The underlying basin-fill deposits are as much as $230 \mathrm{~m}$ thick and form the primary aquifer in the Upper San Pedro Basin (fig. 3; Brown and others, 1966; Pool and Coes, 1999).

Ephemeral-streamflow identification using the temperature methods of Constantz and others (2001) or Blasch and others (2004) was not appropriate for the Sierra Vista Subwatershed. As Blasch and others (2004) note, ephemeral streamflows of less than $24 \mathrm{~h}$ require a temporal resolution greater than that available using the visualinspection method of Constantz and others (2001) in order for estimates of streamflow duration to be of value. Because the quasi-sinusoidal temperature signal is not damped for a full 24-h cycle in short ephemeral streamflows, streamflow may not be readily detected using visual-inspection criteria focused on changes in multiday thermograph amplitudes. While Constantz and others (2001) do not offer an analysis of the temporal resolution of their method, it can be inferred that the onset of streamflow occurs somewhere during the approximately $12-\mathrm{h}$ period between the temperature minimum and maximum (or maximum and minimum) when the thermograph amplitude first decreases, and that streamflow ends days later during a 12-h period when the amplitude increases (although commonly, the amplitude slowly increases over several days). In the ephemeral-stream channels of the Sierra Vista Subwatershed, streamflow can occur for $15 \mathrm{~min}$ or less, and so it was advantageous to develop a streamflowdetection method having a higher temporal resolution than the visual-inspection method of Constantz and others (2001). 


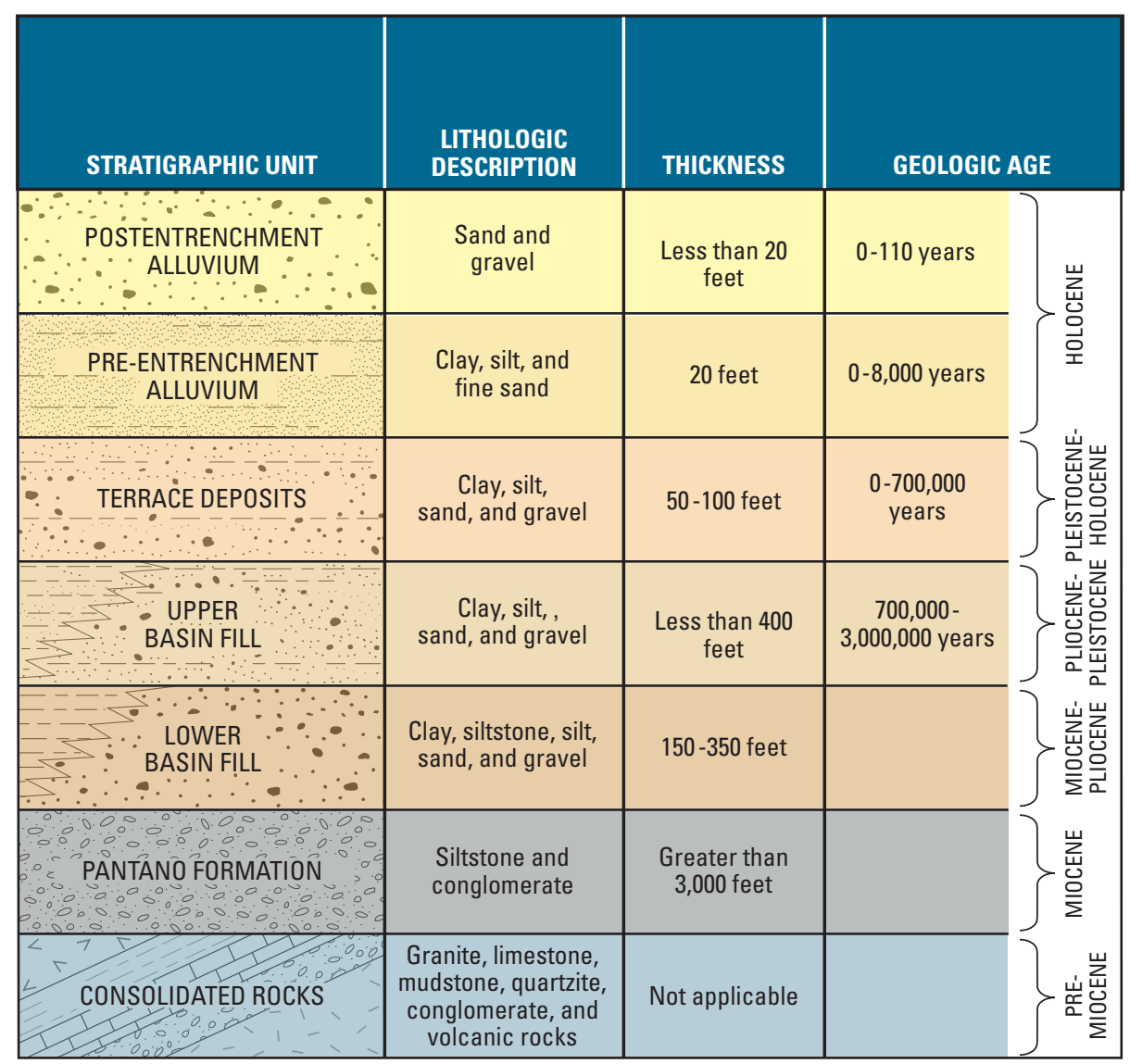

Figure 3. Stratigraphic column of geologic units in the Sierra Vista Subwatershed, Arizona (modified from Pool and Coes, 1999).

The setting of the Blasch and others (2004) study was a single site on Rillito Creek with a surficial bed of 90 percent fine- to coarse-grained alluvium approximately $10 \mathrm{~m}$ thick and that is accessible by heavy equipment. The setting of most of the ephemeral-stream channels in the Sierra Vista Subwatershed is different from that of Rillito Creek.

Where highly permeable sediments exist in the subwatershed, they are quite shallow and frequently underlain by clays at depths less than the 0.75- to 1.0-m depth considered optimal by Blasch and others (2004) for estimating streamflow timing. Although the method of Blasch and others (2004) would provide the temporal resolution required for the short-duration streamflows of the Sierra Vista Subwatershed, the number (48) and commonly remote locations of the temperature sites made it cost prohibitive to use heavy equipment for temperaturelogger installation, and the clays and cobbles would have made it exceptionally labor intensive if not infeasible to install and then periodically download data from all 48 loggers at depths greater than $0.75 \mathrm{~m}$ using pick and shovel. In addition, the determination of 5 parameters at each site to design the site-specific moving standard deviation window would be time consuming for 48 separate locations.
Blasch and others (2002) found that the use of electricalresistance sensors, constructed from the same TidbiT temperature loggers used in this study, required only shallow burial, were more accurate at estimating streamflow timing, and required less time for data interpretation than did available temperature-based methods. Data analysis in this study was well under way, however, before the conclusions of Blasch and others (2002) became available.

A new thermograph-interpretation technique that utilized a relatively shallow deployment of temperature loggers (15-25 $\mathrm{cm}$ below streambed surface) was developed for this investigation. This method uses the thermal signature of the transition from a dry stream channel, dominated by conductive heat transport, to a saturated stream channel, dominated by advective heat transport to identify streamflow onset, and the thermal signature of the transition back to conductive heat transport to identify streamflow cessation. Because streamflow in ephemeral streams of the Desert Southwest is almost always colder than the preexisting streambed temperature, the signature of streamflow onset is a sharp drop in temperature. To be readily recognizable, however, the sharp drop in temperature must exceed the maximum drop found at the inflection point of the thermograph of the dry streambed. 
For the case ${ }^{2}$ where $D=0.10 \mathrm{~m}, z=0.30 \mathrm{~m}$, and $A_{\mathrm{o}}=17^{\circ} \mathrm{C}$, the time of the inflection point (the most rapid drop in temperature, $t_{\mathrm{ip}}$ ) can be determined from equation 7 as $19.63 \mathrm{hr}$ (at the surface the decreasing temperature-inflection point occurs at $12.00 \mathrm{~h}$, midway between dusk and dawn; the sun is at the zenith at $00.00 \mathrm{~h}$, the increasing temperatureinflection point). Inserting the time of the inflection point, plus and then minus $7.5 \mathrm{~min}$, into equation 1 , the maximum rate of temperature change in the dry sediment can be calculated for the 15-min period centered on the point of maximum conductive temperature change: $0.06^{\circ} \mathrm{C}$ over $15 \mathrm{~min}$. For the thermal signature of the transition to advective heat transport to be detectable in the thermograph, the change in the temperature of the bulk sediment, $\Delta T_{\mathrm{s}}$, must exceed this critical temperature drop, $\Delta T_{\text {crit }}$ :

$$
\Delta T_{s}>\Delta T_{\text {crit }} \rightarrow \text { ephemeral streamflow }
$$

Note that equation 3 indicates that at shallower depths, the amplitude of the thermograph will be larger, and because $\omega$ is constant, at shallower depths $\Delta T_{\text {crit }}$ must also increase. Because the diurnal temperature signal is not truly sinusoidal and nor are the channel sediments a homogeneous solid, $\Delta T_{\text {crit }}$ will vary somewhat from the theoretical values.

When streamflow ends, the sediments drain and dry much more slowly than they were initially wetted. For example, Hoffmann and others (2003) found that initial infiltration

${ }^{2}$ Hillel (1998) indicates that $D$ commonly is within the top $10 \mathrm{~cm}$ of a dry sediment. rates in sandy Rillito Creek in Tucson, Arizona, were as high as $3.5 \mathrm{~mm}$ per second (equivalent to a sustained rate of about $300 \mathrm{~m}$ per day), whereas drainage rates after the cessation of streamflow were $0.46 \mathrm{~m}$ per day. As the sediments drain, the primary stream-channel heat transport mechanism shifts back from advection to conduction, and this shift is likewise slower than it was from conduction to advection. As a result, the thermal signature of the transition back to dry sediments from streamflow is more subtle than was the reverse and is complicated by the convection of latent heat away from the sediments (evaporative cooling). Evaporative cooling of the sediments begins when streamflow ends and thus in the right conditions can further cool the bed sediments and provide a low-temperature marker of streamflow cessation (fig. 4).

Evaporative cooling, however, is not always sufficient to lead to a temperature minimum in the bed sediments.

In this report, streamflow cessation is nevertheless identified by the local temperature minimum $\left(T_{\text {min }}\right)$ that immediately follows the sharp temperature drop, as this likely provides the best mean estimate of streamflow cessation. When streamflows occur during the evening and early nighttime hours and dew points are relatively low, evaporative cooling will be high and $T_{\min }$ will provide a fairly accurate estimate of the time of streamflow cessation. During shallow daytime streamflows when solar radiation can result in a significant warming of the water, sediments can rapidly rewarm, and $T_{\min }$ can be earlier than the true time of streamflow cessation.

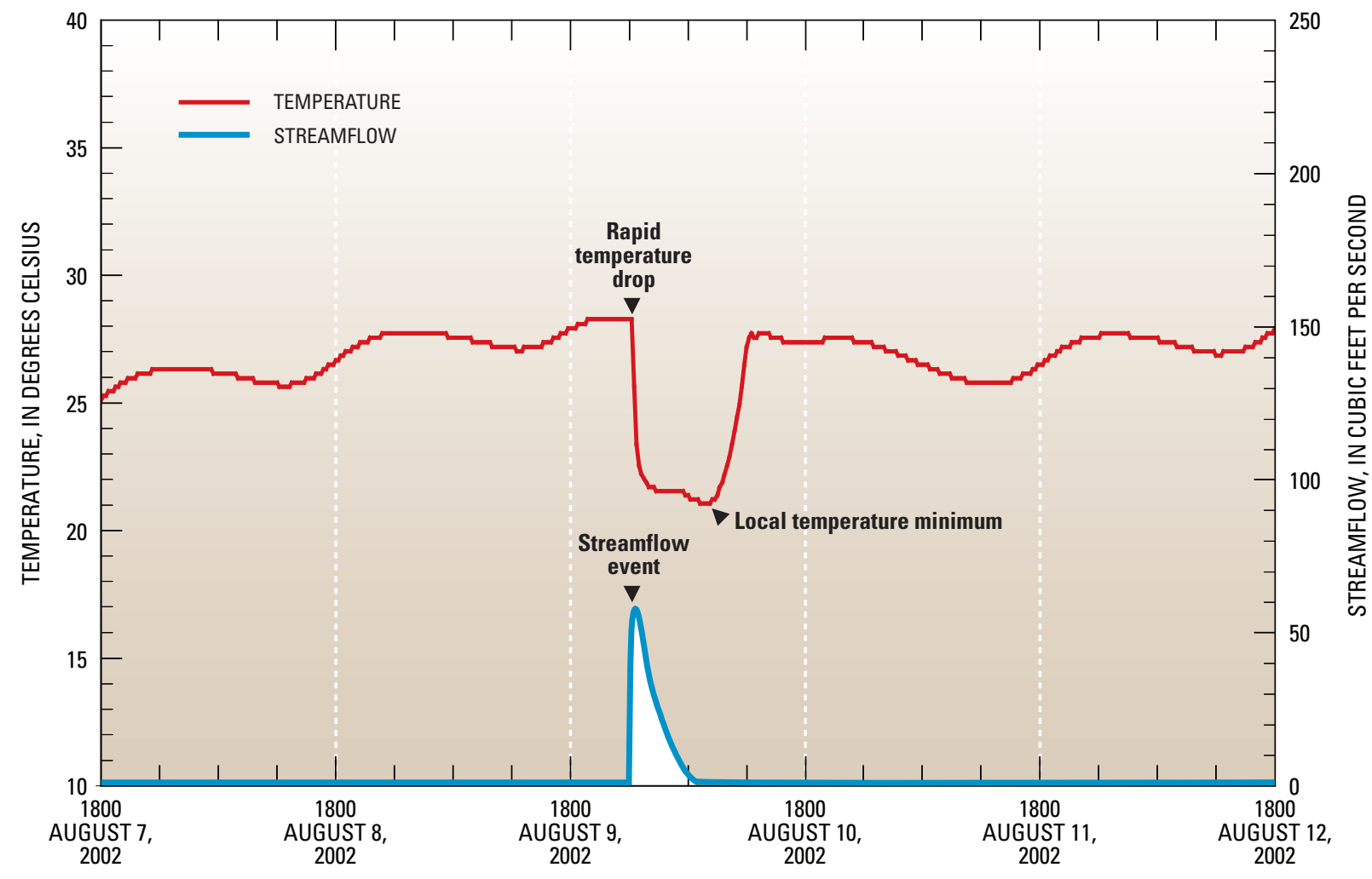

Figure 4. Thermograph and streamflow record from Greenbush Draw, Sierra Vista Subwatershed, Arizona. 
During the late-night to predawn hours when cooling of the atmospheric boundary layer can continue to cool the sediments and delay the time of the temperature minimum, $T_{\min }$ can be later than the true time of streamflow cessation.

To test the method of short term ephemeral-streamflow detection outlined in the previous paragraphs, and to determine at what depth streamflow was most readily determined by using this method, three TidbiT temperature loggers were buried $0.3,0.7$, and $1.0 \mathrm{~m}$ below the channel surface in Greenbush Draw, 10 m downstream from USGS streamflowgaging station 09470520 (GDG, fig. 1). According to the manufacturer, TidbiT loggers have a range of $-5^{\circ} \mathrm{C}$ to $37^{\circ} \mathrm{C}$, a quantization error of $0.085^{\circ} \mathrm{C}$, and an interchangeability of $0.1^{\circ} \mathrm{C}$. Fifteen to twenty centimeters of coarse sand and cobbles overlies a clay layer of greater than $1 \mathrm{~m}$ depth at this location (fig. 5). The timing and duration of streamflows at the gaging station were used as controls and compared to the thermograph for points where $\Delta T_{s}>\Delta T_{\text {crit }}$.

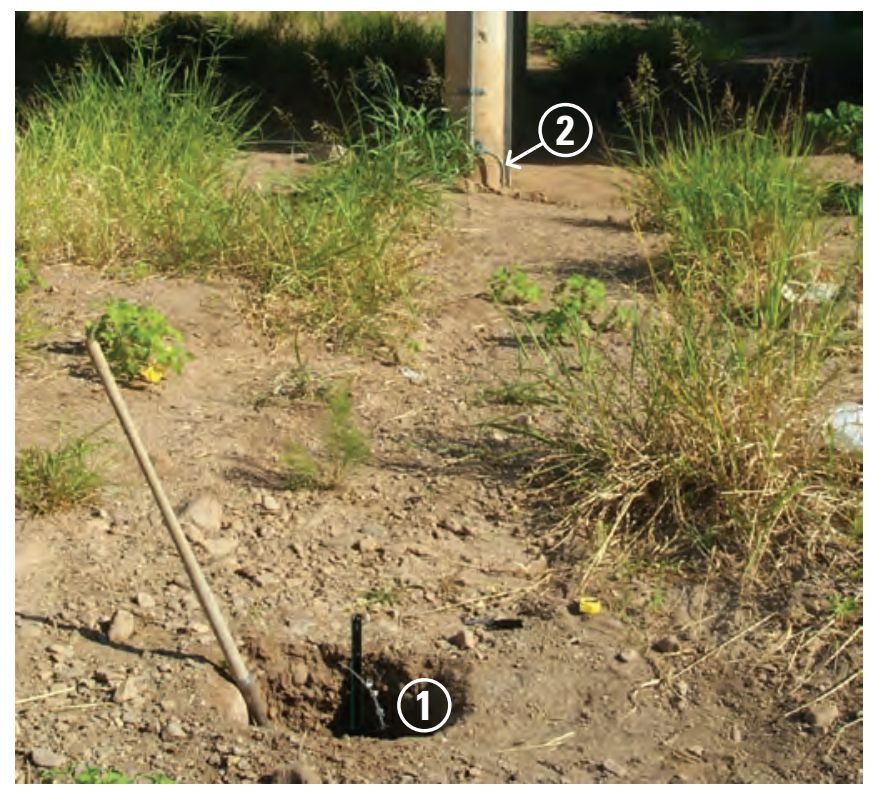

Figure 5. Temperature-method calibration site, Greenbush Draw at State Route 92. The temperature logger site (1) is in the foreground and the U.S. Geological Survey streamflow-gaging station (2) is in the background.

Streamflow occurred 13 times during the summer monsoon of 2002, and the logger at $0.3 \mathrm{~m}$ depth provided the most readily interpretable data of the three logger depths-it provided the largest difference between dry sediment temperature and saturated (streamflow) sediment temperature, was thus most sensitive to all streamflows, including short repeat interval streamflows, and provided the closest approximation of $T_{\min }$ to cessation of streamflow at the gaging station (fig. 6).
Various $\Delta T_{\text {crit }}$ values were used to estimate the time of temperature drop, time of the following local temperature minimum, and elapsed time between the two, and these values are compared to onset of streamflow, cessation of streamflow, and duration of streamflow, respectively, as detected at the Greenbush Draw gaging station from June 1 through September 19, 2002 (table 1).

In order to most accurately detect streamflow, $\Delta T_{\text {crit }}$ must be set to a value that (1) maximizes correct streamflow detections while minimizing false negative and false positive streamflow detections, and (2) minimizes the time between predicted and actual streamflow onset and cessation. Using $\Delta T_{\text {crit }}$ values of $0.20^{\circ} \mathrm{C}, 0.25^{\circ} \mathrm{C}$, and $0.30^{\circ} \mathrm{C}, 11$ of the 13 streamflows ( 85 percent) were correctly identified. Use of $0.20^{\circ} \mathrm{C}$ for $\Delta T_{\text {crit }}$ resulted in 69 percent false positive detections. This decreased to 8 percent for both the $0.25^{\circ} \mathrm{C}$ and the $0.30^{\circ} \mathrm{C}$ values. Thus, for purposes of streamflow detection, $\Delta T_{\text {crit }}$ equal to $0.25^{\circ} \mathrm{C}$ and $0.30^{\circ} \mathrm{C}$ proved optimum.

On the basis of the $0.25^{\circ} \mathrm{C}$ and the $0.30^{\circ} \mathrm{C}$ optimum $\Delta T_{\text {crit }}$ values, the mean difference between the time of streamflow onset at the gaging station and the time at which $\Delta T_{s}$ first exceeded $\Delta T_{\text {crit }}$ was small (37 $\mathrm{min}$ ) as was the standard deviation $(<2 \mathrm{~h})$. The mean difference between the time of streamflow cessation and the time of the temperature minimum following the initial temperature drop was very small (4 min), but the standard deviation was large (nearly $4 \mathrm{~h}$ ). Overall, the gaging station detected 13 events that flowed a total of 4,110 $\mathrm{min}$ ( $68 \mathrm{~h}, 30 \mathrm{~min}$ ), whereas the temperature method detected 12 streamflows that flowed a total of 5,310 $\mathrm{min}(88 \mathrm{~h}, 30 \mathrm{~min})$. The temperature method thus overestimated streamflow duration by about 30 percent. This included one streamflow that was detected by the temperature method but not by the gaging station and therefore is considered a false positive. A sharp drop indicative of streamflow onset will not occur in an otherwise dry streambed; it is possible that a short duration, low-volume streamflow could miss the gaging station orifice but then flow over the temperature logger $10 \mathrm{~m}$ downstream. It is also possible that one or both of the false negatives were a result of the reverse situation: a low-volume streamflow recorded at the gaging station missing the temperature logger site downstream.

In practice, there will be variability in the mean thermalwave amplitude and therefore in $\Delta T_{\text {crit }}$ between and within thermographs, primarily due to variations in burial depth and subsequent scour or deposition. Seasonal differences in the diurnal variation of air temperature as well as length of daylight will also have an effect. Therefore, the relation between a range of diurnal thermal-wave amplitudes and the optimum $\Delta T_{\text {crit }}$ for those amplitudes was determined. This was achieved by installing six TidbiT temperature loggers at 10,15, 20, 25, 30, and $35 \mathrm{~cm}$ below the surface of the streambed in Greenbush Draw. Six streamflows were subsequently recorded at the gaging station during the 2003 summer monsoon. The optimum $\Delta T_{\text {crit }}$ was determined for each of the six loggers as with the three earlier loggers. 


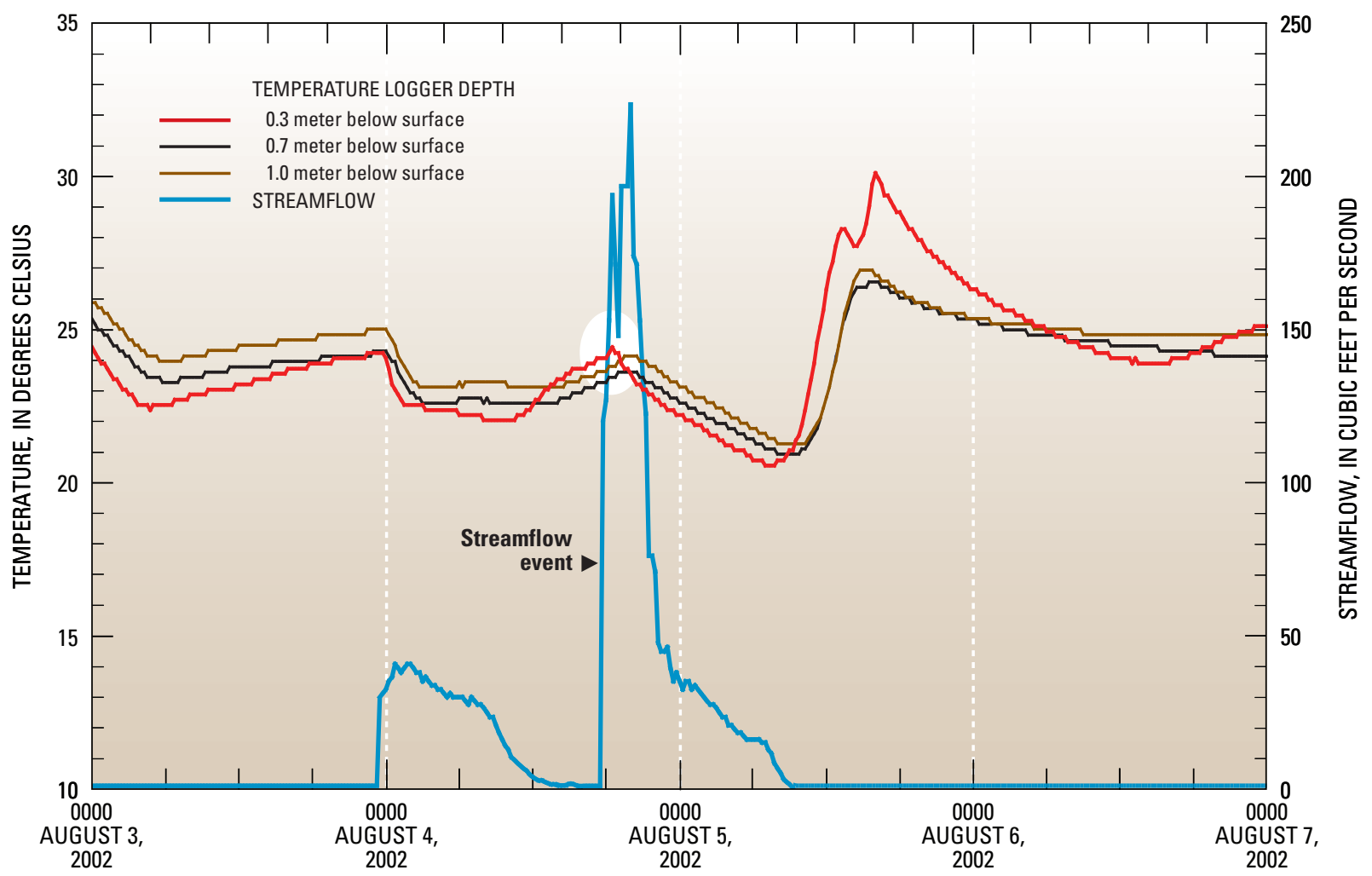

Figure 6. Sensitivity of temperature loggers to streamflow at three depths, Greenbush Draw at State Route 92. The temperature logger at 0.3 meter was sensitive to a streamflow event (white oval) not evident in the thermographs from greater depths. 
Table 1. Temperature-logger streamflow detection compared to streamflow detection at Greenbush Draw gaging station for the period June 1, 2002 , to September 19,2002

[The temperature sensor is 10 meters downstream from the gaging station and 30-33 centimeters below the surface. Values in bold are for the overall optimal temperature drop for streamflow detection (after Gungle, 2003); N, Number; \%, percent; Std. dev., standard deviation]

\begin{tabular}{|c|c|c|c|c|c|c|c|c|c|c|c|c|c|c|c|c|c|c|c|c|}
\hline \multirow[b]{2}{*}{ Streamflow detection } & & \multicolumn{19}{|c|}{$\Delta \mathbf{T}_{\text {crit }}$ (degrees Celsius): } \\
\hline & & 0.20 & 0.25 & 0.30 & 0.35 & 0.40 & 0.45 & 0.50 & 0.55 & 0.60 & 0.65 & 0.70 & 0.75 & 0.80 & 0.85 & 0.90 & 0.95 & 1.00 & 1.05 & 1.10 \\
\hline \multicolumn{21}{|c|}{ Temperature-logger streamflow detection } \\
\hline Flows correctly identified & $\mathrm{N}:$ & 11 & 11 & 11 & 9 & 8 & 8 & 8 & 7 & 7 & 7 & 7 & 6 & 6 & 6 & 6 & 6 & 6 & 6 & 6 \\
\hline (of 13 possible) & $\%$ : & 85 & 85 & 85 & 69 & 62 & 62 & 62 & 54 & 54 & 54 & 54 & 46 & 46 & 46 & 46 & 46 & 46 & 46 & 46 \\
\hline $\begin{array}{l}\text { False negative flow identification } \\
\quad(\text { flows missed } \div \text { total actual flows } \times 100)\end{array}$ & $\%$ : & 15 & 15 & 15 & 31 & 38 & 38 & 38 & 46 & 46 & 46 & 46 & 54 & 54 & 54 & 54 & 54 & 54 & 54 & 54 \\
\hline $\begin{array}{l}\text { False positive flow identification } \\
\quad \text { (false flow identifications } \div \text { total flows } \\
\text { identified } \times 100 \text { ) }\end{array}$ & $\%:$ & 69 & 8 & 8 & 10 & 0 & 0 & 0 & 0 & 0 & 0 & 0 & 0 & 0 & 0 & 0 & 0 & 0 & 0 & 0 \\
\hline Time of flow onset minus time of & Mean: & 37 & 37 & 37 & 33 & 6 & 6 & 2 & -4 & -4 & -4 & -4 & -7 & -7 & -12 & -15 & -15 & -15 & -15 & -15 \\
\hline temperature drop (minutes) & Std. dev.: & 110 & 110 & 110 & 78 & 40 & 40 & 44 & 45 & 45 & 45 & 45 & 48 & 48 & 46 & 44 & 44 & 44 & 44 & 44 \\
\hline Time of flow cessation minus time of local & Mean: & 4 & 4 & 4 & 2 & -34 & -34 & -34 & 11 & 11 & 11 & 10.7 & -32 & -32 & -32 & -32 & -32 & -32 & -32 & -32 \\
\hline minimum temperature (minutes) & Std. dev.: & 232 & 232 & 232 & 251 & 243 & 243 & 243 & 224 & 224 & 224 & 224 & 212 & 212 & 212 & 212 & 212 & 212 & 212 & 212 \\
\hline \multicolumn{21}{|c|}{ Streamflow detection at Greenbush Draw gaging station } \\
\hline Duration of flow minus time from & Mean: & -33 & -33 & -33 & -32 & -39 & -39 & -36 & 15 & 15 & 15 & 15 & -25 & -25 & -20 & -18 & -18 & -18 & -18 & -18 \\
\hline $\begin{array}{l}\text { temperature drop to local minimum } \\
\text { temperature (minutes) }\end{array}$ & Std. dev.: & 231 & 231 & 231 & 204 & 222 & 222 & 220 & 185 & 185 & 185 & 185 & 166 & 166 & 170 & 169 & 169 & 169 & 169 & 169 \\
\hline
\end{tabular}


The standard deviation, $\sigma$, a commonly used and easily calculated measure of the spread of a data set, was used as a surrogate for the amplitude of the conductive temperature signal. The relation between $\Delta T_{\text {crit }}$ and $\sigma$ should be of a form similar to equation 3 :

$$
\sigma=\sigma_{0} e^{\Delta T_{\text {crit }} / C_{1}}
$$

where

$\sigma_{o}=$ the value of the standard deviation at the surface.

Solving for the unknown $\Delta T_{\text {crit }}$,

$$
\Delta T_{\text {crit }}=C_{1} \ln (\sigma)+C_{2},
$$

where

$C_{1}$ and $C_{2}$ are constants.

Once these two constants are determined, equation 11 can be used to determine $\Delta T_{\text {crit }}$ for any thermograph $\sigma$.

Because the standard deviation is strongly affected by extreme data points (used to advantage by Blasch and others, 2004 , as the indicator of streamflow), a period of days when the conductive temperature signal is relatively even and uninterrupted is required for the determination of $\sigma$. For the summer monsoon of 2003 at Greenbush Draw, this period was from September 4 to September 22, 2003. Consistent with equations 1 and 3, the amplitude of the temperature signal in the more shallow temperature loggers was higher (as indicated by an increase in temperature variability characterized by a larger value for $\sigma$ ) and $\Delta T_{\text {crit }}$ was likewise larger. The $\sigma$ versus $\Delta T_{\text {crit }}$ data were then plotted, and a natural log curve consistent with equation 11 was fitted to the data (fig. 7; $C_{1}=0.40$, $\left.\mathrm{C}_{2}=0.47\right)$. Values from the curve were then used to create a look-up table for thermograph data analysis. Once $\sigma$ was determined for a thermograph (or thermograph subset), the look-up table provided the $\Delta T_{\text {crit }}$ required to detect streamflow.

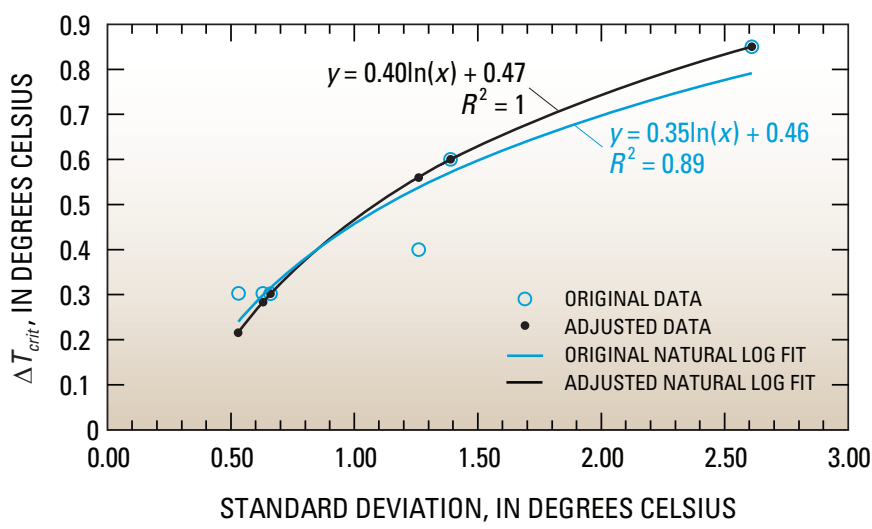

Figure 7. Original and adjusted natural log fits for $\Delta T_{\text {crit }}$ versus standard deviation of temperature from Greenbush Draw at State Route 92, monsoon 2003, for logger burial depths of 10, 15, 20, 25, 30 , and 35 centimeters below streambed surface.
Thermograph data from the temperature loggers installed throughout the Sierra Vista Subwatershed were then analyzed using the following procedure:

1. Thermograph data from a given location were separated into periods of similar streambed-temperature amplitudes. Typically, annual data were broken into three periods, October to January, February to May, and June to September.

2. A subperiod of no less than a full week of relatively constant mean temperature and amplitude was then selected and the subperiod standard deviation, $\sigma$, determined.

3. The critical temperature change, $\Delta \mathrm{T}_{\text {crit }}$, corresponding to $\sigma$, was determined from the look-up table developed using equation 11 .

4. The data were matched against the $\Delta T_{\text {crit }}$ determined in 3 and any change in the temperature of the bulk sediment, $\Delta T_{s}$, over a 15 -min period that exceeded $\Delta T_{\text {crit }}$ was interpreted as streamflow onset, whereas the subsequent temperature minimum was interpreted as the time of streamflow cessation.

Early in the study, some loggers were set to log every $30 \mathrm{~min}$. The 30 -min data required larger $\Delta T_{\text {crit }}$ values in a separate look-up table in order to be correctly interpreted $\left(C_{1}=0.36\right.$ and $\left.C_{2}=0.51\right)$. By the end of the first 9 months of data collection, nearly all loggers had been reset to log every 15 min.

Because a diurnal temperature minimum will occur within about $24 \mathrm{~h}$ of any streamflow, the use of $T_{\min }$ as a method to determine streamflow cessation is limited to streamflows that last no more than 1 day. This method is also less effective at identifying individual streamflows that occur in rapid succession (within $24 \mathrm{~h}$ or less) than it is at identifying more widely separated streamflows when the streambed sediments have been able to dry and rewarm to near prestreamflow temperatures. For both of these reasons, streamflows that occurred during the frequent and heavy rains of October and November 2000 were difficult to interpret and are not included in this report. In addition, much of the temperature logger network was not yet operational at that time.

\section{Installation of Temperature Loggers}

Data stored in the Tidbit temperature loggers used in this study are downloaded using an optical interface that accesses the data through two small plastic nipples on the face of the logger. To protect these interface nipples from detritus carried along in ephemeral streamflows, each logger was housed in a 10- to 15-cm-long piece of 4- or 5-cm-diameter polyvinyl chloride (PVC) pipe. These in turn were tethered with 1 to $3 \mathrm{~m}$ of cable to either a 1-m metal T-post installed in the channel bottom, or to an in situ anchor such as a tree root, a small tree trunk, or an existing fence post. Loggers were then buried in the channel sediments (fig. 8). 


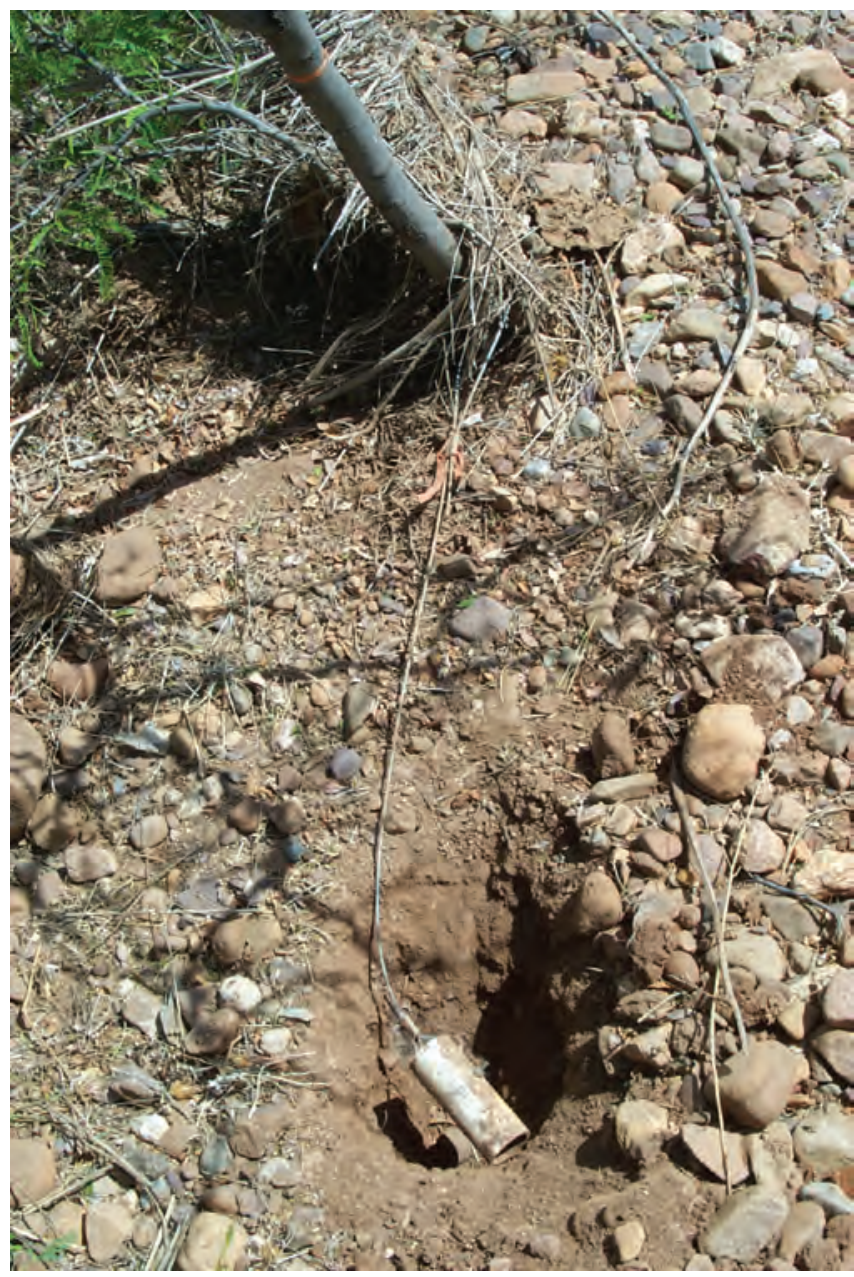

Figure 8. Typical field deployment of temperature logger in a polyvinyl chloride (PVC) housing tethered to a small tree trunk with airplane cable.

After early streamflows drew many loggers to the surface, loggers were reburied and this time anchored in place with weights. Sensors buried $<10 \mathrm{~cm}$ deep produced excessively noisy data owing to the limited attenuation of the conductive signal through the shallow sediment. This was exacerbated in areas where tree branches, streambanks, or physical structures produced periodic shading of the surface above the logger. The resulting thermographs were generally uninterpretable. Loggers were then reburied to depths of 15 to $25 \mathrm{~cm}$. Although a uniform burial depth will not remove all interthermograph amplitude and $\Delta T_{\text {crit }}$ variation, it will limit the amount of variation to be expected from one location to the next, and makes data processing more efficient. For the same reason, it is best to install loggers where intermittent shading from trees or structures will not occur.

A final concern was that in channels downstream from impermeable surfaces, such as road crossings and parking lots, runoff from modest precipitation events can be focused and result in streamflows limited in linear extent and volume.
Although such events are localized - not system wide-in nature, loggers installed downstream from such surfaces will nevertheless indicate streamflow, which can be misleading in terms of streamflow extent. For example, two loggers that both record streamflow downstream from road crossings separated by $4 \mathrm{~km}$ of channel will imply that streamflow occurred over the entire 4-km segment of channel, when in fact, streamflow only occurred over a few tens to hundreds of meters. Because these events represent small magnitude runoff from street drainage rather than large magnitude streamflow events, they give an inaccurate representation of what is occurring along the length of the channel. This problem is resolved by moving loggers upstream from areas of localized drainage.

\section{Monitoring Sites}

Temperature loggers were installed in 19 ephemeralstream channels across the subwatershed. Three gaging stations in Walnut Gulch, operated by the Agricultural Research Service, provided data for the 20th channel and are included in the data set, as are data from the USGS gaging station on Greenbush Draw at State Route 92. Although the data are not used in this report, three USGS gaging stations in the Huachuca Mountains and one USGS gaging station in the Mule Mountains monitored streamflow from mountains (fig. 1).

A greater number of large ephemeral-stream channel systems occur on the west side of the subwatershed than on the east. This is reflected in the distribution of temperature loggers across the subwatershed; 14 ephemeral-stream channels were monitored on the west side of the river, whereas 6 were monitored on the east. Similarly, 37 loggers were deployed on the west side and 16 on the east, amounting to 53 total temperature loggers (fig. 1) of which 48 returned useful data. In addition, all 4 gaging stations on ephemeral streams were operational throughout most of the monitoring period for a total of 52 monitoring sites across the subwatershed that provided useful ephemeral-streamflow data.

Each ephemeral-stream channel reported on here contained a minimum of two data points along the channel length. In five channels, however, one logger did not provide any useable data throughout the entire monitoring period (all on the west side, 3 rural, 2 urban: Brown Wash south of State Route 92, Ash Canyon Wash at Stone Ridge Road, Soldier Creek at Irwin Road, Huachuca Canyon Wash at Backer Road, and Coyote Wash at State Route 92). In the cases of Brown Wash, Ash Canyon Wash, Soldier Creek, and Huachuca Canyon Wash, where just two loggers were deployed, there was thus only one useful data point, whereas in Coyote Wash, two useful data points remained. Three loggers were deployed in Coyote, Miller Canyon, and Woodcutters Washes, Wash 1, Graveyard Gulch, and Government Draw; four loggers were deployed in Garden and Ramsey Washes; and six loggers were deployed along Greenbush Draw. 
Seven loggers were deployed in or immediately downstream from urbanized areas (Huachuca Canyon Wash at Backer Road, Soldier Creek at State Route 90 Bypass, Woodcutters Wash at Seventh Street, Woodcutters Wash at State Route 90 Bypass, Coyote Wash at State Route 92, Garden Canyon Wash at State Route 92, and Miller Canyon Wash at State Route 92) of which five provided useful data. Six loggers were deployed within $1 \mathrm{~km}$ of the foot of the Huachuca Mountains, and two loggers were deployed within $1 \mathrm{~km}$ of the foot of the Mule Mountains. Four loggers were within about $1 \mathrm{~km}$ of the San Pedro River (three west, one east), and seven were within about $3 \mathrm{~km}$ of the river (three west, four east; table 2).

\section{Precipitation Patterns During the Monitoring Period}

Following the dry winter of 1999-2000, when precipitation in the Sierra Vista Subwatershed was 15 percent of the 30-yr average, annual precipitation was well above average for 2000, owing in part to a wet summer season (around 135 percent of average) but more importantly to a series of large storms in October and early November of that year (fig. 2). For the study period beginning December 2000, nonmonsoon precipitation in 2000-2001 and 2001-2002 was 82 percent and 39 percent of the 30 -yr average, respectively. Monsoon precipitation during the study period (summer 2001) was 99 percent of the 30-yr average.

\section{Timing and Duration of Flow in Ephemeral Streams}

The duration and frequency of streamflow were expected to vary as functions of distance from the mountains, and thus logger data were separated into bins on the basis of the distance of the logger site from the mountain front on either side of the basin. In this report, "mountain front" refers to the point along the foot of the mountains where basin sediments contact the mountain block, and can be identified by a sharp change in slope. On the west side of the subwatershed, the Huachuca Mountain front approximates a straight line and ephemeral-stream channels are relatively straight and parallel. On the east side, the mountain front is highly irregular and thus "distance from mountain front" refers to the approximate stream distance from where a given stream exits the region of steeper slope.

Data from the west side were entered into bins having 3-km widths beginning at the mountain front and ending at the river. Data from the east side were entered into bins having $5-\mathrm{km}$ widths beginning at the mountain front. The larger bin width was needed for the east side because of the greater length of some east side streams. Because the number of sites within the bins varied, the data were normalized relative to the largest number of data sites, $N_{L}$, found in any one of the bins for the given period being analyzed. $N_{L}$ can thus be considered the virtual number of logger sites for each of the bins being compared. The normalized values of the number and duration of streamflows, $V_{N}$, is thus calculated:

$$
\Delta T_{N}=\left(N_{L} / N_{A}\right) \mathrm{I}
$$

where

$$
\begin{aligned}
& N_{A}=\begin{array}{l}
\text { the actual number of data sites in the given } \\
\text { bin, and }
\end{array} \\
& V_{A}=\begin{array}{l}
\text { the actual value (number or duration of } \\
\text { streamflows) in the given bin. }
\end{array}
\end{aligned}
$$

Data thus normalized for the purposes of comparison should not be mistaken for absolute values. The absolute number and duration of streamflows occurring at each monitoring site are listed in the appendix of this report.

\section{Spatial Streamflow Patterns}

Results of the thermograph data analysis indicate that streamflow commonly occurs along much of the length of the ephemeral-stream channels of the Sierra Vista Subwatershed at some time in all but the driest years (figs. 9-16). This is not to say that streamflow occurred along the entire length of a channel during any one event or even any one season. Rather, in the course of a year, streamflow occurs at most points along most channels. During the 18-month monitoring period, streamflow was detected at least once at all but 6 of the 52 functional monitoring sites ( 88 percent), although 4 of the 6 no-streamflow sites were not functioning during the 2001 monsoon. Streamflow occurred at at least 1 site in each of the 20 channels during the study period; streamflow also occurred at least once at every site along 16 of the 20 channels (80 percent), although only rarely did streamflow occur at more than one site in a given channel as a result of the same precipitation event. Locations with more than 40 percent uninterpretable or missing data over a given time period were not included in the analysis of streamflow patterns.

During the 2000-2001 and 2001-2002 nonmonsoon periods, streamflows peaked in number, total streamflow duration, and mean streamflow duration (mean streamflow duration $=$ total streamflow duration/number of streamflows) midway between the mountains and river on the west side of the subwatershed, with the greatest number and duration of streamflows occurring between 6 and $9 \mathrm{~km}$ from the Huachuca Mountain front (figs. 11, 15, 17A, B). All three streamflow parameters dropped off rapidly beyond $12 \mathrm{~km}$ from the Huachuca Mountain front, with no streamflows observed from 12 to $15 \mathrm{~km}$ during the 2000-2001 nonmonsoon period (fig. 17A). 
Table 2. Approximate distances between ephemeral-stream monitoring sites and mountain fronts

[SPRNCA, San Pedro Riparian National Conservation Area; C, central; Mtns., Mountains; NE, northeastern; S, southern]

\begin{tabular}{|c|c|c|}
\hline \multicolumn{3}{|c|}{ West-side monitoring sites } \\
\hline Location & $\begin{array}{c}\text { Distance } \\
\text { east of } \\
\text { Mountains } \\
\text { (kilometers) }\end{array}$ & $\begin{array}{c}\text { (U)rbanized/ } \\
\text { (N)onurbanized } \\
\text { location }\end{array}$ \\
\hline Garden Canyon gaging station & 0.0 & $\mathrm{~N}$ \\
\hline Huachuca Canyon gaging station & 0.0 & $\mathrm{~N}$ \\
\hline Huachuca Canyon Wash at Backer Rd. & 0.0 & $\mathrm{U}$ \\
\hline Hunter Canyon Wash at State Route 92 & 0.0 & $\mathrm{~N}$ \\
\hline Ramsey Canyon gaging station & 0.0 & $\mathrm{~N}$ \\
\hline Stump Canyon at State Route 92 & 0.0 & $\mathrm{~N}$ \\
\hline Ash Canyon at Stone Ridge Rd. & 0.0 & $\mathrm{~N}$ \\
\hline Brown Canyon Wash at Coronado Memorial Rd. & 0.0 & $\mathrm{~N}$ \\
\hline Ramsey Canyon Wash at Ramsey Rd. (RC1) & 1.0 & $\mathrm{~N}$ \\
\hline Ash Canyon Wash at Coronado Memorial Rd. & 1.0 & $\mathrm{~N}$ \\
\hline Miller Canyon Wash at State Route 92 & 1.5 & $\mathrm{U}$ \\
\hline Carr Canyon Wash at State Route 92 & 2.0 & $\mathrm{~N}$ \\
\hline Soldier Creek Wash at Irwin Rd. & 2.5 & $\mathrm{~N}$ \\
\hline $\begin{array}{l}\text { Garden Canyon Wash at Fort Huachuca south } \\
\text { perimeter (GC1) }\end{array}$ & 2.5 & $\mathrm{~N}$ \\
\hline $\begin{array}{l}\text { Huachuca Canyon Wash at Monitor Site Rd., } \\
\text { Fort Huachuca }\end{array}$ & 3.5 & $\mathrm{~N}$ \\
\hline Ramsey Canyon Wash at State Route 92 (RC2) & 3.5 & $\mathrm{~N}$ \\
\hline Brown Canyon Wash at Hutchinson Rd. & 4.0 & $\mathrm{~N}$ \\
\hline Stump Canyon Wash at Deer Canyon Trail & 4.0 & $\mathrm{~N}$ \\
\hline Woodcutters Canyon Wash at 7th St. & 4.5 & $\mathrm{U}$ \\
\hline Hunter Canyon Wash at Hereford Rd. & 5.0 & $\mathrm{~N}$ \\
\hline Garden Canyon Wash at State Route 92 (GC2) & 5.5 & $\mathrm{U}$ \\
\hline Soldier Creek Wash at State Route 90 Bypass & 6.0 & $\mathrm{U}$ \\
\hline Miller Canyon Wash at Moson Rd. & 7.5 & $\mathrm{~N}$ \\
\hline Coyote Wash at State Route 92 & 8.0 & $\mathrm{U}$ \\
\hline Carr Canyon Wash at Moson Rd. & 9.0 & $\mathrm{~N}$ \\
\hline $\begin{array}{l}\text { Woodcutters Canyon Wash at State Route } 90 \\
\text { Bypass }\end{array}$ & 9.5 & $\mathrm{U}$ \\
\hline Ramsey Canyon Wash at La Donna Rd. (RC3) & 10.0 & $\mathrm{~N}$ \\
\hline Graveyard Gulch, middle arm & 11.0 & $\mathrm{~N}$ \\
\hline Graveyard Gulch, south arm & 11.0 & $\mathrm{~N}$ \\
\hline Garden Canyon Wash at Moson Rd. (GC3) & 11.0 & $\mathrm{~N}$ \\
\hline Graveyard Gulch, north arm & 13.0 & $\mathrm{~N}$ \\
\hline Coyote Wash at Dake Rd. & 13.5 & $\mathrm{~N}$ \\
\hline Wash 1 , south arm & 13.5 & $\mathrm{~N}$ \\
\hline Wash 1 , middle arm & 14.5 & $\mathrm{~N}$ \\
\hline
\end{tabular}

\begin{tabular}{|c|c|c|}
\hline \multicolumn{3}{|c|}{ West-side monitoring sites-Continued } \\
\hline Location & $\begin{array}{c}\text { Distance } \\
\text { east of } \\
\text { Mountains } \\
\text { (kilometers) }\end{array}$ & $\begin{array}{c}\text { (U)rbanized/ } \\
\text { (N)onurbanized } \\
\text { location }\end{array}$ \\
\hline Wash 1 , north arm & 14.5 & $\mathrm{~N}$ \\
\hline Miller Canyon Wash at the SPRNCA & 14.5 & $\mathrm{~N}$ \\
\hline Ramsey Canyon Wash at the SPRNCA (RC4) & 15.0 & $\mathrm{~N}$ \\
\hline Coyote Wash at Moson Rd. & 16.0 & $\mathrm{~N}$ \\
\hline Garden Canyon Wash at the SPRNCA (GC4) & 16.5 & $\mathrm{~N}$ \\
\hline $\begin{array}{l}\text { Woodcutters Canyon Wash at Moson Rd. } \\
\text { extension }\end{array}$ & 17.0 & $\mathrm{~N}$ \\
\hline \multicolumn{3}{|c|}{ East-side monitoring sites } \\
\hline Location & $\begin{array}{c}\text { Distance } \\
\text { west of } \\
\text { Mountains } \\
\text { (kilometers) }\end{array}$ & Mountain front \\
\hline Banning Creek gaging station & 0.0 & C Mule Mtns. \\
\hline Banning Creek at State Route 80 & 0.0 & C Mule Mtns. \\
\hline Wash 20 at State Route 80 & 4.0 & NE Mule Mtns. \\
\hline Spring Wash at Foudy Rd. & 4.0 & C Mule Mtns. \\
\hline Banning Creek at Misty Ray Rd. & 6.0 & C Mule Mtns. \\
\hline Greenbush Draw at Naco Highway (GD1) & 8.5 & S Mule Mtns. \\
\hline Wash 20 at High Knoll Rd. (south) & 9.0 & NE Mule Mtns. \\
\hline Wash 20 at High Knoll Rd. (north) & 9.0 & NE Mule Mtns. \\
\hline $\begin{array}{l}\text { Spring Wash at railroad bridge north of } \\
\text { Hereford Rd. }\end{array}$ & 9.5 & C Mule Mtns. \\
\hline Greenbush Draw east Ladd Ranch (GD2) & 11.5 & S Mule Mtns. \\
\hline Walnut Gulch, flume 6 & 16.5 & Dragoon Mtns. \\
\hline Government Draw at State Route 80 & 16.5 & $\begin{array}{l}\text { Tombstone Hills/ } \\
\text { NE Mule Mtns. }\end{array}$ \\
\hline Greenbush Draw at railroad tracks (GD4) & 17.5 & S Mule Mtns. \\
\hline Government Draw on Cox Ranch & 19.5 & $\begin{array}{l}\text { Tombstone Hills/ } \\
\text { NE Mule Mtns. }\end{array}$ \\
\hline $\begin{array}{l}\text { Greenbush Draw at State Route } 92 \text { gaging } \\
\text { station (GDG) }\end{array}$ & 23.0 & S Mule Mtns. \\
\hline Walnut Gulch, flume 1 & 24.0 & Dragoon Mtns. \\
\hline $\begin{array}{l}\text { Government Draw at High Knoll Rd. } \\
\text { extension }\end{array}$ & 24.0 & $\begin{array}{l}\text { Tombstone Hills/ } \\
\text { NE Mule Mtns. }\end{array}$ \\
\hline Greenbush Draw at Fox Hollow Rd. (GD6) & 25.0 & S Mule Mtns. \\
\hline Greenbush Draw tributary at Foudy Rd. (GD5) & NA & S Mule Mtns. \\
\hline Walnut Gulch, flume 11 (tributary) & NA & Dragoon Mtns. \\
\hline Greenbush Dray tributary at Sand Wash (GD3) & NA & S Mule Mtns. \\
\hline
\end{tabular}




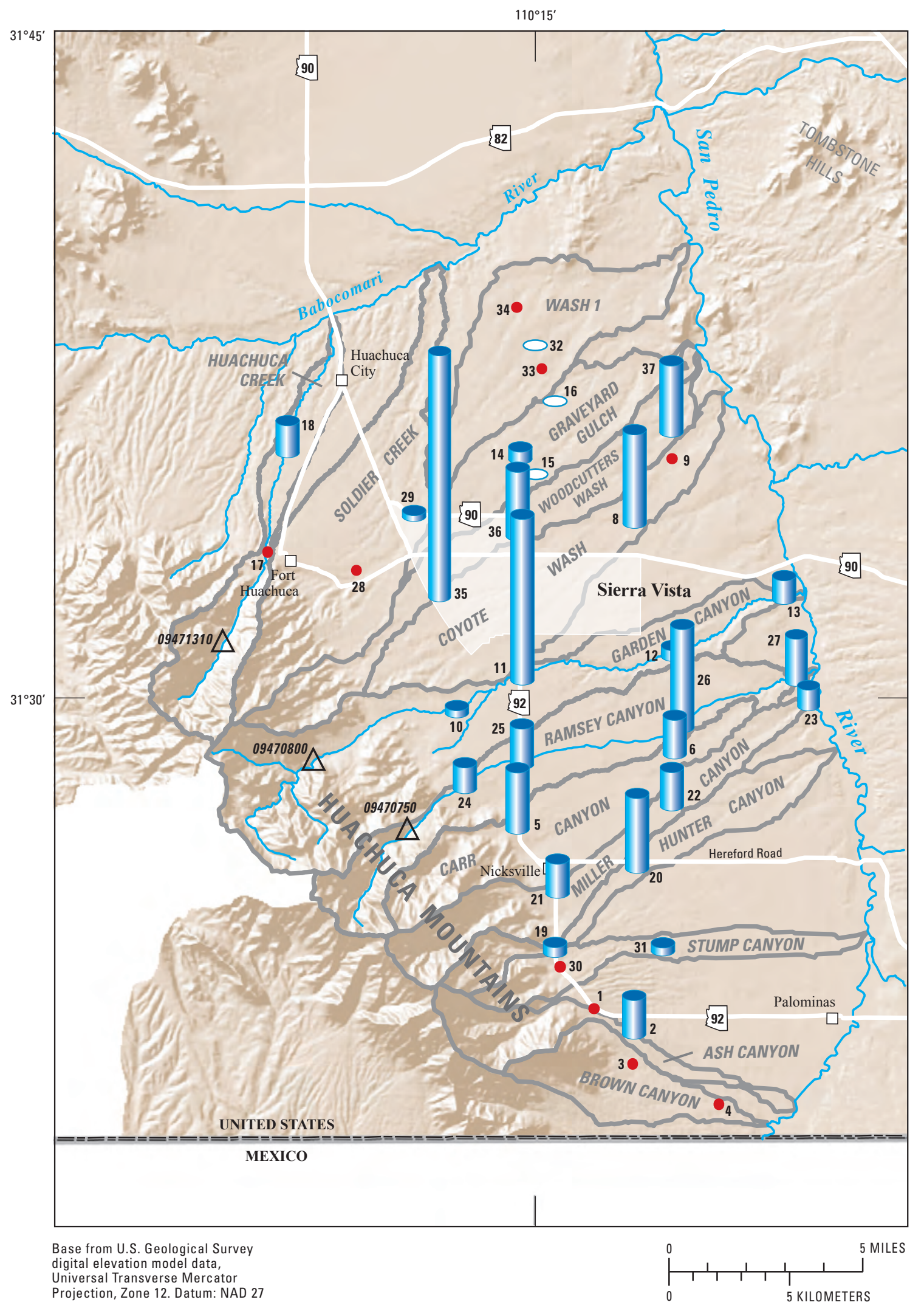

Figure 9. Duration of ephemeral streamflow at temperature-logger sites in the Sierra Vista Subwatershed, Arizona, west side, for the entire period of study, December 1, 2000, to May 31, 2002. For name, total-duration data, and number of flows for each site, see explanation on page 18. 


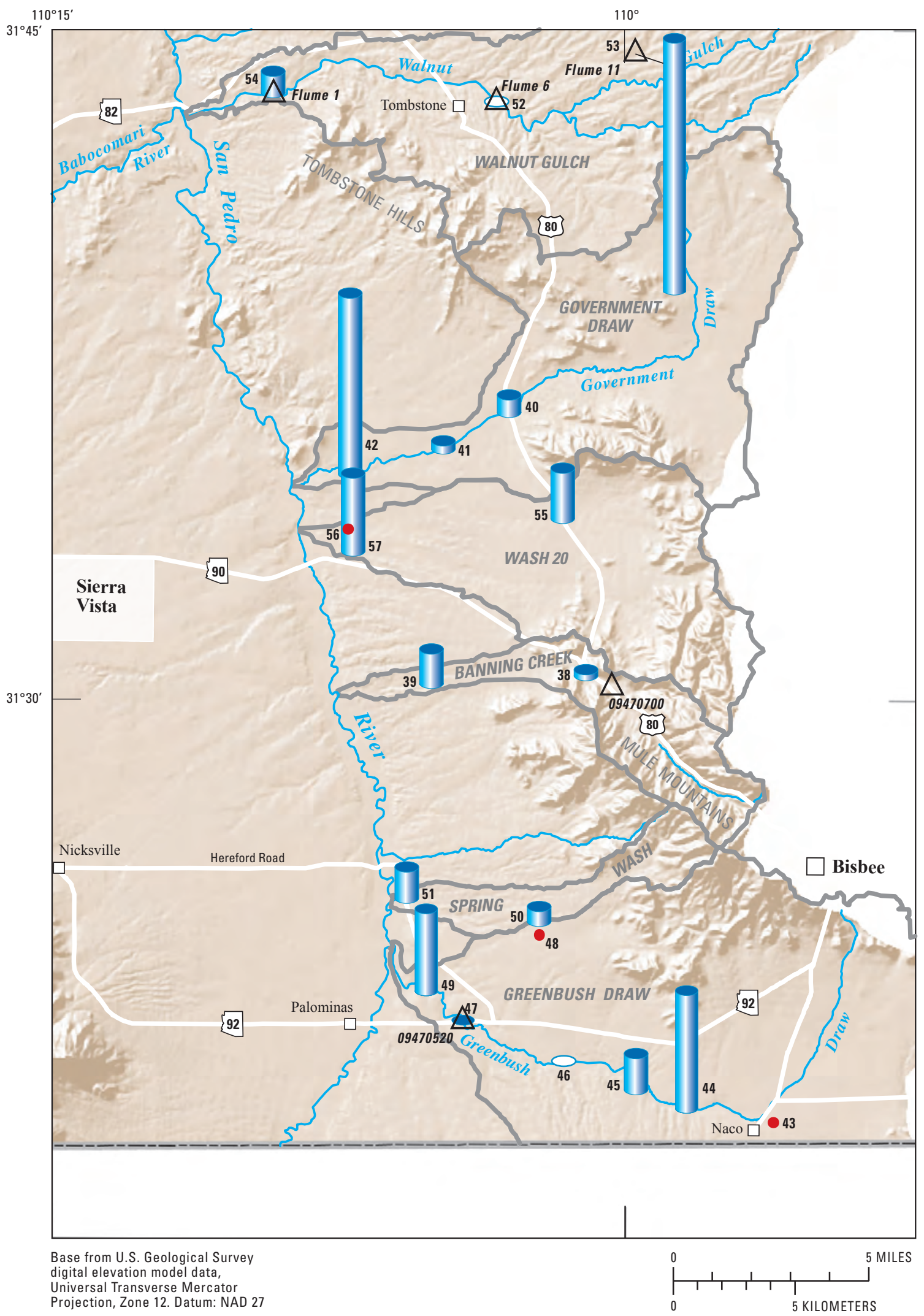

Figure 10. Duration of ephemeral streamflow at temperature-logger sites and at selected streamflow-gaging stations in the Sierra Vista Subwatershed, Arizona, east side, for the entire period of study, December 1, 2000, to May 31, 2002. For name, total-duration data, and number of flows for each site, see explanation on page 18. 


\title{
EXPLANATION FOR FIGURES 9 AND 10 (entire period of study)
}

\author{
DRAINAGE BASIN BOUNDARY \\ TEMPERATURE LOGGER SITE-Height of cylinder indicates relative duration of ephemeral streamflow. \\ 55 Actual minutes can be found in list below. Number identifies name of site location in list below \\ $09471310 \triangle$ STREAMFLOW-gaging STATION \\ $52 \bigcirc$ TEMPERATURE LOGgER SITE OR STREAMFLOW-gAgING STATION WITH NO FLOW- \\ Number identifies name of site location in list below \\ 28 TEMPERATURE LOGGER SITE WITH BAD OR MISSING DATA-Number identifies name of site location in list below
}

NUMBERED LIST OF TEMPERATURE-LOGGER SITES AND STREAMFLOW-GAGING STATION WITH SELECTED FLOW DATA

\begin{tabular}{|c|c|c|c|c|c|}
\hline SLOPE WEST OF SAN PEDRO RIVER & $\begin{array}{l}\text { Duration } \\
\text { of Flow } \\
\text { in Minutes }\end{array}$ & $\begin{array}{l}\text { Number } \\
\text { of Flows }\end{array}$ & SLOPE EAST OF SAN PEDRO RIVER & $\begin{array}{l}\text { Duration } \\
\text { of Flow } \\
\text { in Minutes }\end{array}$ & $\begin{array}{l}\text { Number } \\
\text { of Flows }\end{array}$ \\
\hline 1. Ash Canyon at Stone Ridge .. & - & & 38. Banning Creek at U.S. Route $80 \ldots \ldots \ldots \ldots \ldots$ & 165 & 2 \\
\hline 2. Ash Canyon at Coronado Memorial Road ..... & 1,125 & 4 & 39. Banning Creek at Misty Ray Road . ............ & 990 & 3 \\
\hline 3. Brown Canyon at Coronado Memorial Road. & $\bullet$ & & 40. Government Draw at U.S. Route 80 . & 495 & 4 \\
\hline 4. Brown Canyon south of Arizona Route 92 . & - & & 41. Government Draw at Cox Ranch. & 225 & 3 \\
\hline 5. Carr Canyon at Arizona Route $92 .$. & 1,800 & 4 & 42. Government Draw at High Knoll Road & & \\
\hline 6. Carr Canyon at Moson Road .... & 1,125 & 6 & (extension)................... & 5,310 & 9 \\
\hline 7. Coyote Wash at Arizona Route 92 . & • & & 43. Greenbush Draw at Naco Highway... & $\bullet$ & \\
\hline 8. Coyote Wash at Dake Road. . & 2,760 & 8 & 44. Greenbush Draw east of Ladds' house .......... & 3,450 & 11 \\
\hline 9. Coyote Wash at Moson Road $\ldots \ldots \ldots \ldots \ldots \ldots \ldots \ldots \ldots \ldots \ldots \ldots \ldots \ldots \ldots \ldots \ldots \ldots$ & 15 & 1 & 45. Greenbush Draw tributary, Sand Wash .......... & 1,035 & 3 \\
\hline 10. Garden Canyon at Fort Huachuca perimeter $\ldots \ldots \ldots \ldots \ldots \ldots \ldots \ldots$ & 195 & 5 & 46. Greenbush Draw at railroad bridge ..... & 0 & 0 \\
\hline 11. Garden Canyon at Arizona Route 92. & 4,905 & 11 & 47. Greenbush Draw streamflow-gaging & 15 & \\
\hline 12. Garden Canyon at Moson Road .... & 300 & 6 & & 15 & 1 \\
\hline 13. Garden Canyon at the San Pedro Riparian National Conservation Area . & 675 & 7 & 48. Greenbush Draw tributary at Foudy Road & $\bullet$ & \\
\hline 14. Graveyard Gulch, Middle Arm . & 345 & 4 & 49. Greenbush Draw at Fox Hollow Road. & 2,400 & 4 \\
\hline 15. Graveyard Gulch, South Arm .. & - & & 50. Spring Wash at Foudy Road. & 420 & 6 \\
\hline 16. Graveyard Gulch, North Arm .......... & 0 & 0 & 51. Spring Wash at Hereford Road.. & 900 & 1 \\
\hline 17. Huachuca Creek at Backer Road ........ & - & & 52. Walnut Gulch Flume $6 \ldots \ldots \ldots \ldots$ & 0 & 0 \\
\hline 18. Huachuca Creek at gravity station "field". & 930 & 10 & 53. Walnut Gulch Flume $11 \ldots \ldots \ldots \ldots$ & 7,478 & 6 \\
\hline 19. Hunter Canyon at Arizona Route $92 .$. & 285 & 1 & 54. Walnut Gulch Flume $1 \ldots \ldots \ldots \ldots \ldots$ & 615 & 5 \\
\hline 20. Hunter Canyon at Hereford Road ........... & 2,205 & 12 & 55. Wash 20 at U.S. Route $80 \ldots \ldots \ldots$ & 1,470 & 4 \\
\hline 21. Miller Canyon at Arizona Route 92. & 990 & 3 & 56. Wash 20 at High Knoll Road, North Arm ... & - & \\
\hline 22. Miller Canyon at Moson Road ..... & 1,110 & 6 & 57. Wash 20 at High Knoll Road, South Arm . & 2,280 & 6 \\
\hline 23. Miller Canyon at the San Pedro Riparian National Conservation Area & 450 & 3 & & & \\
\hline 24. Ramsey Canyon at Ramsey Canyon Road $\ldots \ldots \ldots \ldots \ldots \ldots \ldots \ldots \ldots$ & 735 & 3 & & & \\
\hline 25. Ramsey Canyon at Arizona Route $92 .$. & 1,200 & 8 & & & \\
\hline 26. Ramsey Canyon at La Donna Road $\ldots \ldots \ldots \ldots \ldots \ldots \ldots \ldots \ldots \ldots \ldots \ldots \ldots \ldots$ & 3,045 & 10 & & & \\
\hline 27. Ramsey Canyon at the San Pedro Riparian National Conservation Area . & 1,380 & 5 & & & \\
\hline 28. Soldier Creek at Irwin Road... & $\bullet$ & & & & \\
\hline 29. Soldier Creek at Arizona Route 90 Bypass .. & 165 & 3 & & & \\
\hline 30. Stump Canyon at Arizona Route $92 \ldots \ldots \ldots$ & - & & & & \\
\hline 31. Stump Canyon at Deer Canyon Trail ......... & 225 & 2 & & & \\
\hline 32. Wash 1, South Arm ............. & 0 & 0 & & & \\
\hline 33. Wash 1, Middle Arm ................. & $\bullet$ & & & & \\
\hline 34. Wash 1 North Arm $\ldots \ldots \ldots \ldots \ldots \ldots \ldots \ldots \ldots \ldots \ldots$ & - & & & & \\
\hline 35. Woodcutters Wash at 7 th Street $\ldots \ldots \ldots \ldots \ldots \ldots \ldots \ldots \ldots \ldots \ldots \ldots \ldots \ldots \ldots \ldots$ & 7,290 & 17 & & & \\
\hline 36. Woodcutters Wash at Arizona Route 90 Bypass ...... & 2,025 & 8 & & & \\
\hline 37. Woodcutters Wash at Moson Road (extension) . & 2,100 & 8 & & & \\
\hline
\end{tabular}


This page left blank intentionally. 


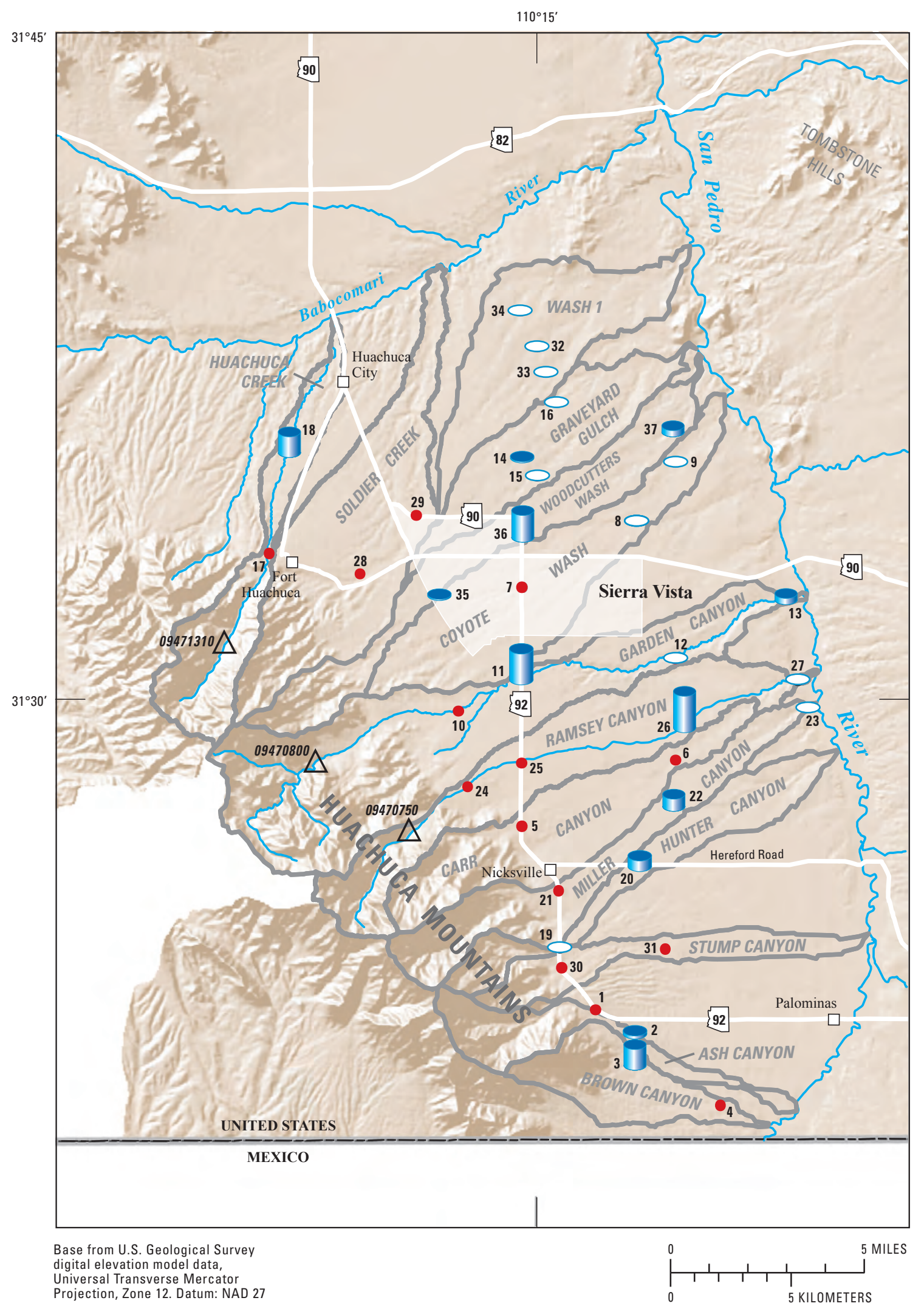

Figure 11. Duration of ephemeral streamflow at temperature-logger sites in the Sierra Vista Subwatershed, Arizona, west side, 2000-2001 nonmonsoon (December 1, 2000, to May 31, 2001). For name, total-duration data, and number of flows for each site, see explanation on page 22. 


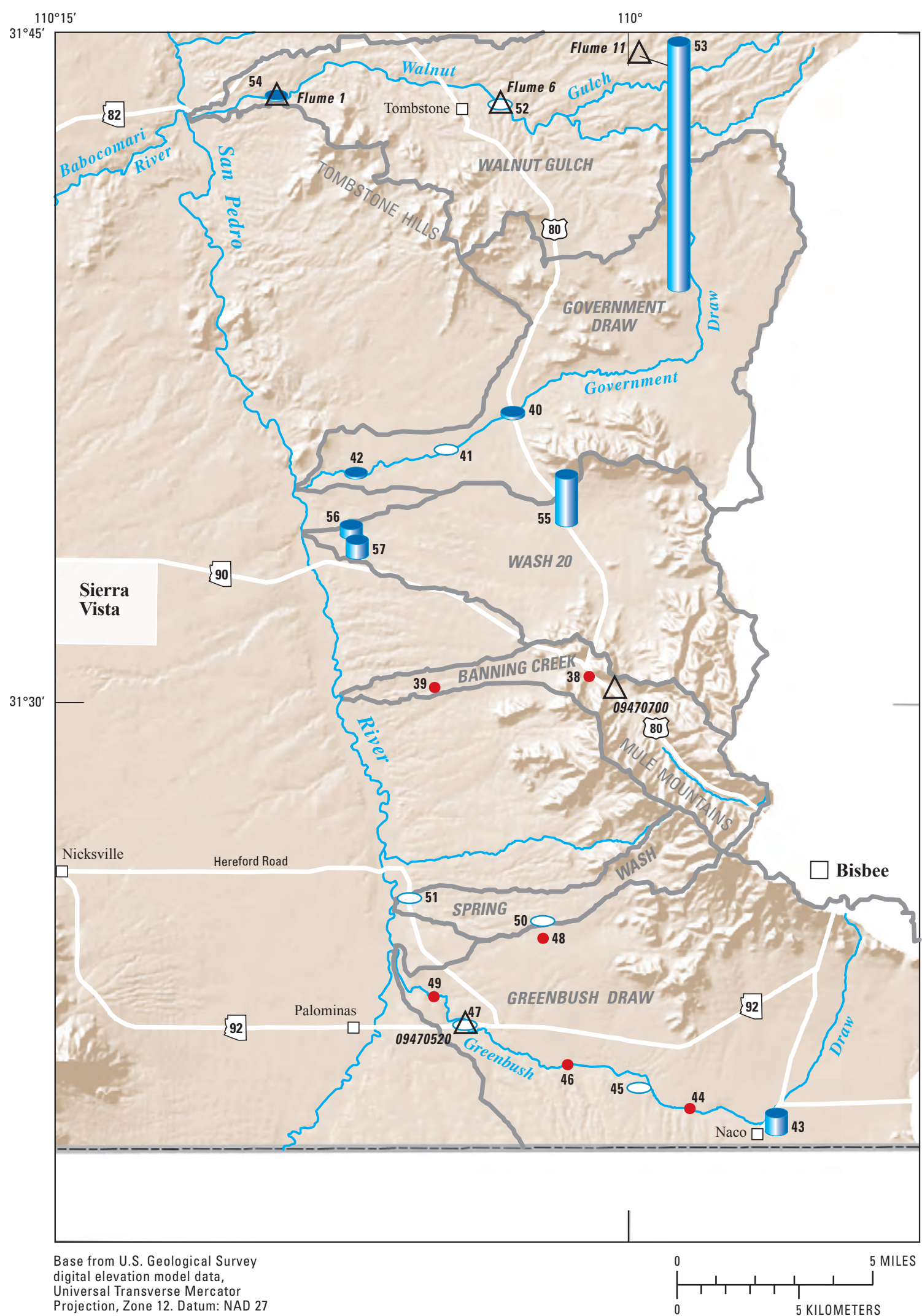

Figure 12. Duration of ephemeral streamflow at temperature-logger sites and at selected streamflow-gaging stations in the Sierra Vista Subwatershed, Arizona, east side, 2000-2001 nonmonsoon (December 1, 2000, to May $31,2001)$. For name, total-duration data, and number of flows for each site, see explanation on page 22. 
EXPLANATION FOR FIGURES 11 AND 12 (December 1, 2000, to May 31, 2001)

\author{
DRAINAGE BASIN BOUNDARY \\ 11 Temperature LOGger Site-Height of cylinder indicates relative duration of ephemeral streamflow. \\ Actual minutes $c$ an be found in list below. Number identifies name of site location in list below \\ $09471310 \triangle$ STREAMFLOW-gAgING STATION \\ $52 \bigcirc$ TEMPERATURE LOGGER SITE OR STREAMFLOW-GAGING STATION WITH NO FLOW- \\ Number identifies name of site location in list below \\ 28 TEMPERATURE LOGGER SITE WITH BAD OR MISSING DATA-Number identifies name of site location in list below
}

NUMBERED LIST OF TEMPERATURE-LOGGER SITES AND STREAMFLOW-GAGING STATION WITH SELECTED FLOW DATA

\begin{tabular}{|c|c|c|c|c|c|}
\hline SLOPE WEST OF SAN PEDRO RIVER & $\begin{array}{c}\text { Duration } \\
\text { of Flow } \\
\text { in Minutes }\end{array}$ & $\begin{array}{l}\text { Number } \\
\text { of Flows }\end{array}$ & SLOPE EAST OF SAN PEDRO RIVER & $\begin{array}{l}\text { Duration } \\
\text { of Flow } \\
\text { in Minutes }\end{array}$ & $\begin{array}{l}\text { Number } \\
\text { of Flows }\end{array}$ \\
\hline 1. Ash Canyon at Stone Ridge ..... & - & & 38. Banning Creek at U.S. Route $80 \ldots \ldots \ldots \ldots \ldots$ & - & \\
\hline 2. Ash Canyon at Coronado Memorial Road ............ & 90 & 2 & 39. Banning Creek at Misty Ray Road ............. & ? & \\
\hline 3. Brown Canyon at Coronado Memorial Road... & 600 & 1 & 40. Government Draw at U.S. Route $80 \ldots$... & 90 & 1 \\
\hline 4. Brown Canyon south of Arizona Route 92 . . & ○ & & 41. Government Draw at Cox Ranch ......... & 0 & 0 \\
\hline 5. Carr Canyon at Arizona Route 92 . & 0 & & 42. Government Draw at High Knoll Road & & \\
\hline 6. Carr Canyon at Moson Road. . & ○ & & (extension) ...................... & 60 & 1 \\
\hline 7. Coyote Wash at Arizona Route $92 \ldots \ldots \ldots$ & ○ & & 43. Greenbush Draw at Naco Highway ............. & 510 & 2 \\
\hline 8. Coyote Wash at Dake Road.... & 0 & 0 & 44. Greenbush Draw east of Ladds' house .......... & ? & \\
\hline 9. Coyote Wash at Moson Road . . . . . . . . . . . . . . . . . . . . . . . & 0 & 0 & 45. Greenbush Draw tributary, Sand Wash .......... & 0 & 0 \\
\hline 10. Garden Canyon at Fort Huachuca perimeter .................... & - & & 46. Greenbush Draw at railroad bridge ............ & ? & \\
\hline 11. Garden Canyon at Arizona Route 92. & 900 & 1 & 47. Greenbush Draw streamflow-gaging & 0 & \\
\hline 12. Garden Canyon at Moson Road. & 0 & 0 & 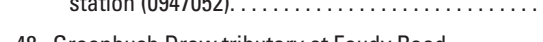 & 0 & 0 \\
\hline 13. Garden Canyon at the San Pedro Riparian National Conservation Area .. & 180 & 1 & 48. Greenbush Draw tributary at Foudy Road. & 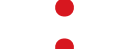 & \\
\hline 14. Graveyard Gulch, Middle Arm .... & 30 & 1 & 49. Greenbush Draw at Fox Hollow Road ........... & 0 & \\
\hline 15. Graveyard Gulch, South Arm ... & 0 & 0 & 50. Spring Wash at Foudy Road ................ & 0 & 0 \\
\hline 16. Graveyard Gulch, North Arm ..... & 0 & 0 & 51. Spring Wash at Hereford Road.. & 0 & 0 \\
\hline 17. Huachuca Creek at Backer Road.... & - & & 52. Walnut Gulch Flume $6 \ldots \ldots \ldots$ & 0 & 0 \\
\hline 18. Huachuca Creek at gravity station "field". & 600 & 1 & 53. Walnut Gulch Flume $11 \ldots \ldots \ldots \ldots$ & 7,232 & 2 \\
\hline 19. Hunter Canyon at Arizona Route $92 \ldots$ & 0 & 0 & 54. Walnut Gulch Flume $1 \ldots \ldots$ & 45 & 1 \\
\hline 20. Hunter Canyon at Hereford Road. & 300 & 2 & 55. Wash 20 at U.S. Route $80 \ldots \ldots \ldots \ldots \ldots \ldots \ldots$ & 1,380 & 2 \\
\hline 21. Miller Canyon at Arizona Route 92 . & $\bullet$ & & 56. Wash 20 at High Knoll Road, North Arm .......... & 270 & 1 \\
\hline 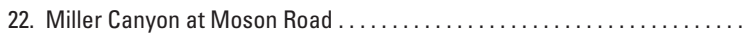 & 360 & 1 & 57. Wash 20 at High Knoll Road, South Arm ......... & 420 & 3 \\
\hline 23. Miller Canyon at the San Pedro Riparian National Conservation Area ... & 0 & 0 & & & \\
\hline 24. Ramsey Canyon at Ramsey Canyon Road. & - & & & & \\
\hline 25. Ramsey Canyon at Arizona Route 92. & - & & & & \\
\hline 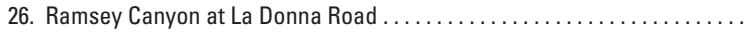 & 1,080 & 3 & & & \\
\hline 27. Ramsey Canyon at the San Pedro Riparian National Conservation Area .. & 0 & 0 & & & \\
\hline 28. Soldier Creek at Irwin Road ................. & - & & & & \\
\hline 29. Soldier Creek at Arizona Route 90 Bypass .... & - & & & & \\
\hline 30. Stump Canyon at Arizona Route 92 . & - & & & & \\
\hline 31. Stump Canyon at Deer Canyon Trail . . & - & & & & \\
\hline 32. Wash 1, South Arm ......... & 0 & 0 & & & \\
\hline 33. Wash 1, Middle Arm ........... & 0 & 0 & & & \\
\hline 34. Wash 1 North Arm .................. & 0 & 0 & & & \\
\hline 35. Woodcutters Wash at 7th Street......... & 30 & 1 & & & \\
\hline 36. Woodcutters Wash at Arizona Route 90 Bypass . & 780 & 1 & & & \\
\hline 37. Woodcutters Wash at Moson Road (extension). . & 180 & 1 & & & \\
\hline
\end{tabular}


This page left blank intentionally. 


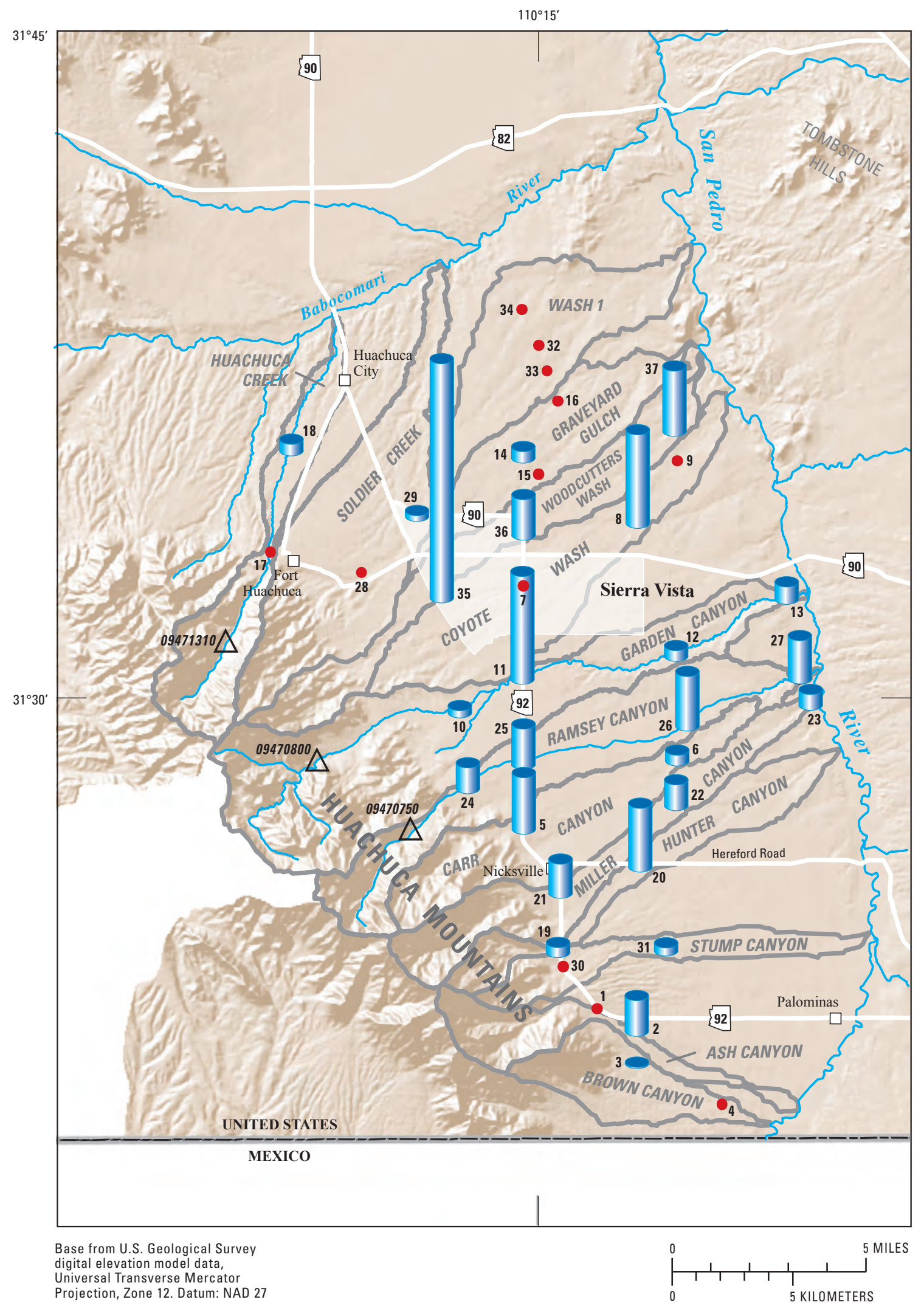

Figure 13. Duration of ephemeral streamflow at temperature-logger sites in the Sierra Vista Subwatershed, Arizona, west side, 2001 monsoon (June 1, 2001, to September 19, 2001). For name, total-duration data, and number of flows for each site, see explanation on page 26 . 


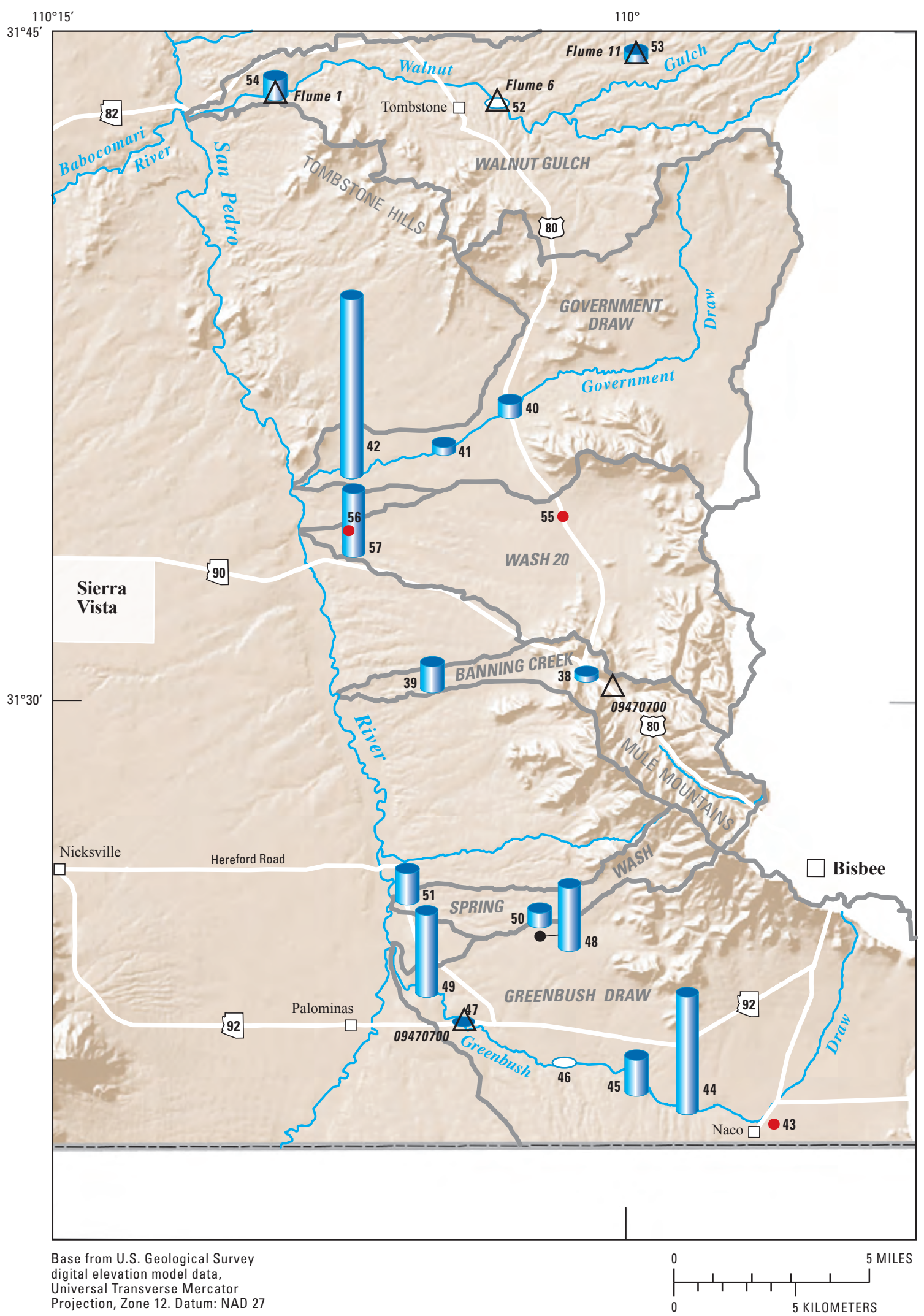

Figure 14. Duration of ephemeral streamflow at temperature-logger sites and at selected streamflow-gaging stations in the Sierra Vista Subwatershed, Arizona, east side, 2001 monsoon (June 1, 2001, to September 19, 2001). For name, total-duration data, and number of flows for each site, see explanation on page 26. 
EXPLANATION FOR FIGURES 13 AND 14 (June 1, 2001, to September 19, 2001)

\author{
DRAINAGE BASIN BOUNDARY \\ .10 \\ TEMPERATURE LOGGER SITE-Height of cylinder indicates relative duration of ephemeral streamflow. \\ Actual minutes can be found in list below. Number identifies name of site location in list below \\ $09471310 \triangle$ STREAMFLOW-gaging STATION \\ $52 \bigcirc$ TEMPERATURE LOGgER SITE OR STREAMFLOW-GAGING STATION WITH NO FLOW- \\ Number identifies name of site location in list below \\ 34 TEMPERATURE LOGGER SITE WITH BAD OR MISSING DATA-Number identifies name of site location in list below
}

NUMBERED LIST OF TEMPERATURE-LOGGER SITES AND STREAMFLOW-GAGING STATION WITH SELECTED FLOW DATA

\begin{tabular}{|c|c|c|c|c|c|}
\hline SLOPE WEST OF SAN PEDRO RIVER & $\begin{array}{l}\text { Duration } \\
\text { of Flow } \\
\text { in Minutes }\end{array}$ & $\begin{array}{l}\text { Number } \\
\text { of Flows }\end{array}$ & SLOPE EAST OF SAN PEDRO RIVER & $\begin{array}{l}\text { Duration } \\
\text { of Flow } \\
\text { in Minutes }\end{array}$ & $\begin{array}{l}\text { Number } \\
\text { of Flows }\end{array}$ \\
\hline 1. Ash Canyon at Stone Ridge . & - & & 38. Banning Creek at U.S. Route $80 \ldots \ldots$ & 165 & 2 \\
\hline 2. Ash Canyon at Coronado Memorial Road ....... & 1,035 & 2 & 39. Banning Creek at Misty Ray Road & 750 & 2 \\
\hline 3. Brown Canyon at Coronado Memorial Road ............ & 30 & 1 & 40. Government Draw at U.S. Route $80 \ldots \ldots \ldots \ldots$ & 405 & 3 \\
\hline 4. Brown Canyon south of Arizona Route 92 . & 0 & & 41. Government Draw at Cox Ranch ............. & 225 & 3 \\
\hline 5. Carr Canyon at Arizona Route 92 . & 1,665 & 3 & 42. Government Draw at High Knoll Road & & \\
\hline 6. Carr Canyon at Moson Road. & 300 & 5 & (extension) .............. & 5,250 & 8 \\
\hline 7. Coyote Wash at Arizona Route $92 .$. & ○ & & 43. Greenbush Draw at Naco Highway............ & $\bullet$ & \\
\hline 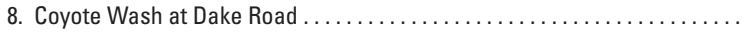 & 2,760 & 8 & 44. Greenbush Draw east of Ladds' house .......... & 3,450 & 11 \\
\hline 9. Coyote Wash at Moson Road. & ○ & & 45. Greenbush Draw tributary, Sand Wash.......... & 1,035 & 3 \\
\hline 10. Garden Canyon at Fort Huachuca perimeter $\ldots \ldots \ldots \ldots \ldots \ldots \ldots$ & 195 & 5 & 46. Greenbush Draw at railroad bridge ............ & 0 & 0 \\
\hline 11. Garden Canyon at Arizona Route $92 \ldots .$. & 3,195 & 8 & 47. Greenbush Draw streamflow-gaging & & \\
\hline 12. Garden Canyon at Moson Road. . & 300 & 6 & & 15 & 1 \\
\hline 13. Garden Canyon at the San Pedro Riparian National Conservation Area .. & 495 & 6 & 48. Greenbush Draw tributary at Foudy Road. & 1,845 & 6 \\
\hline 14. Graveyard Gulch, Middle Arm .. & 315 & 3 & 49. Greenbush Draw at Fox Hollow Road. & 2,400 & 4 \\
\hline 15. Graveyard Gulch, South Arm ... & - & & 50. Spring Wash at Foudy Road. . & 420 & 6 \\
\hline 16. Graveyard Gulch, North Arm ...... & - & & 51. Spring Wash at Hereford Road... & 900 & 1 \\
\hline 17. Huachuca Creek at Backer Road........ & - & & 52. Walnut Gulch Flume $6 \ldots$ & 0 & 0 \\
\hline 18. Huachuca Creek at gravity station "field". & 330 & 9 & 53. Walnut Gulch Flume $11 \ldots \ldots \ldots \ldots$ & 246 & 4 \\
\hline 19. Hunter Canyon at Arizona Route 92 . & 285 & 1 & 54. Walnut Gulch Flume $1 \ldots \ldots$. & 570 & 4 \\
\hline 20. Hunter Canyon at Hereford Road.. & 1,905 & 10 & 55. Wash 20 at U.S. Route $80 \ldots \ldots$ & 0 & \\
\hline 21. Miller Canyon at Arizona Route 92 . & 990 & 3 & 56. Wash 20 at High Knoll Road, North Arm & $0_{100}$ & \\
\hline 22. Miller Canyon at Moson Road .............. & 750 & 5 & 57. Wash 20 at High Knoll Road, South & 1,860 & 3 \\
\hline 23. Miller Canyon at the San Pedro Riparian National Conservation Area ... & 450 & 3 & & & \\
\hline 24. Ramsey Canyon at Ramsey Canyon Road $\ldots \ldots \ldots \ldots \ldots \ldots \ldots \ldots \ldots \ldots$ & 735 & 3 & & & \\
\hline 25. Ramsey Canyon at Arizona Route 92 . & 1,200 & 8 & & & \\
\hline 26. Ramsey Canyon at La Donna Road $\ldots \ldots \ldots \ldots \ldots \ldots \ldots \ldots \ldots \ldots \ldots \ldots \ldots \ldots \ldots \ldots \ldots \ldots \ldots$ & 1,605 & 6 & & & \\
\hline 27. Ramsey Canyon at the San Pedro Riparian National Conservation Area .. & 1,260 & 4 & & & \\
\hline 28. Soldier Creek at Irwin Road ..... & - & & & & \\
\hline 29. Soldier Creek at Arizona Route 90 Bypass . & 165 & 3 & & & \\
\hline 30. Stump Canyon at Arizona Route 92 . & - & & & & \\
\hline 31. Stump Canyon at Deer Canyon Trail . & 225 & 2 & & & \\
\hline 32. Wash 1, South Arm ................. & ? & & & & \\
\hline 33. Wash 1, Middle Arm ....... & - & & & & \\
\hline 34. Wash 1 North Arm .... & ○ & & & & \\
\hline 35. Woodcutters Wash at 7th Street...... & 7,260 & 16 & & & \\
\hline 36. Woodcutters Wash at Arizona Route 90 Bypass ..... & 1,200 & 6 & & & \\
\hline 37. Woodcutters Wash at Moson Road (extension) .. & 1,920 & 7 & & & \\
\hline
\end{tabular}


This page left blank intentionally. 


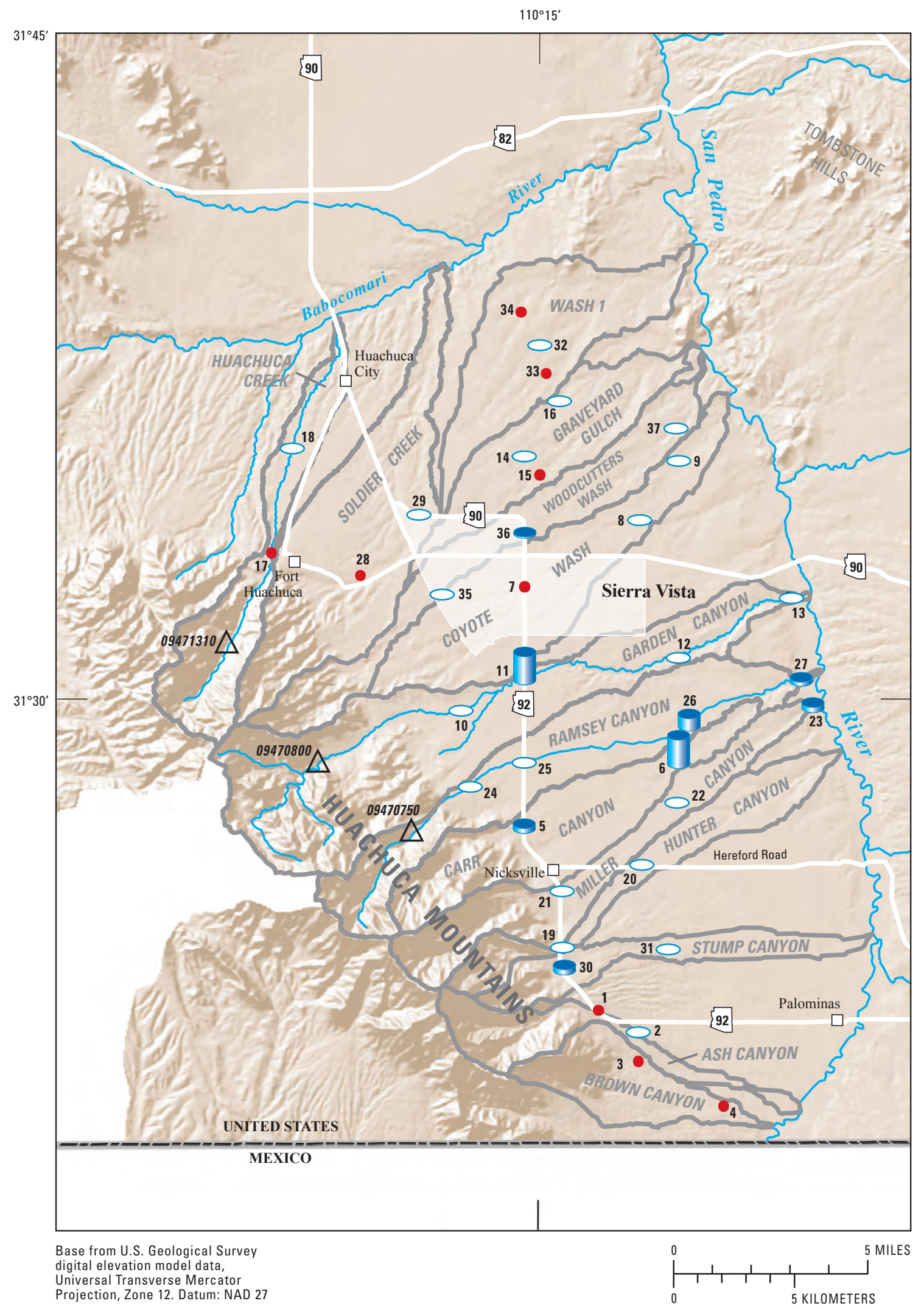

Figure 15. Duration of ephemeral streamflow at temperature-logger sites in the Sierra Vista Subwatershed, Arizona, west side, 2001-2002 nonmonsoon (September 20, 2001, to May 31, 2002). For name, total-duration data, and number of flows for each site, see explanation on page 30 . 


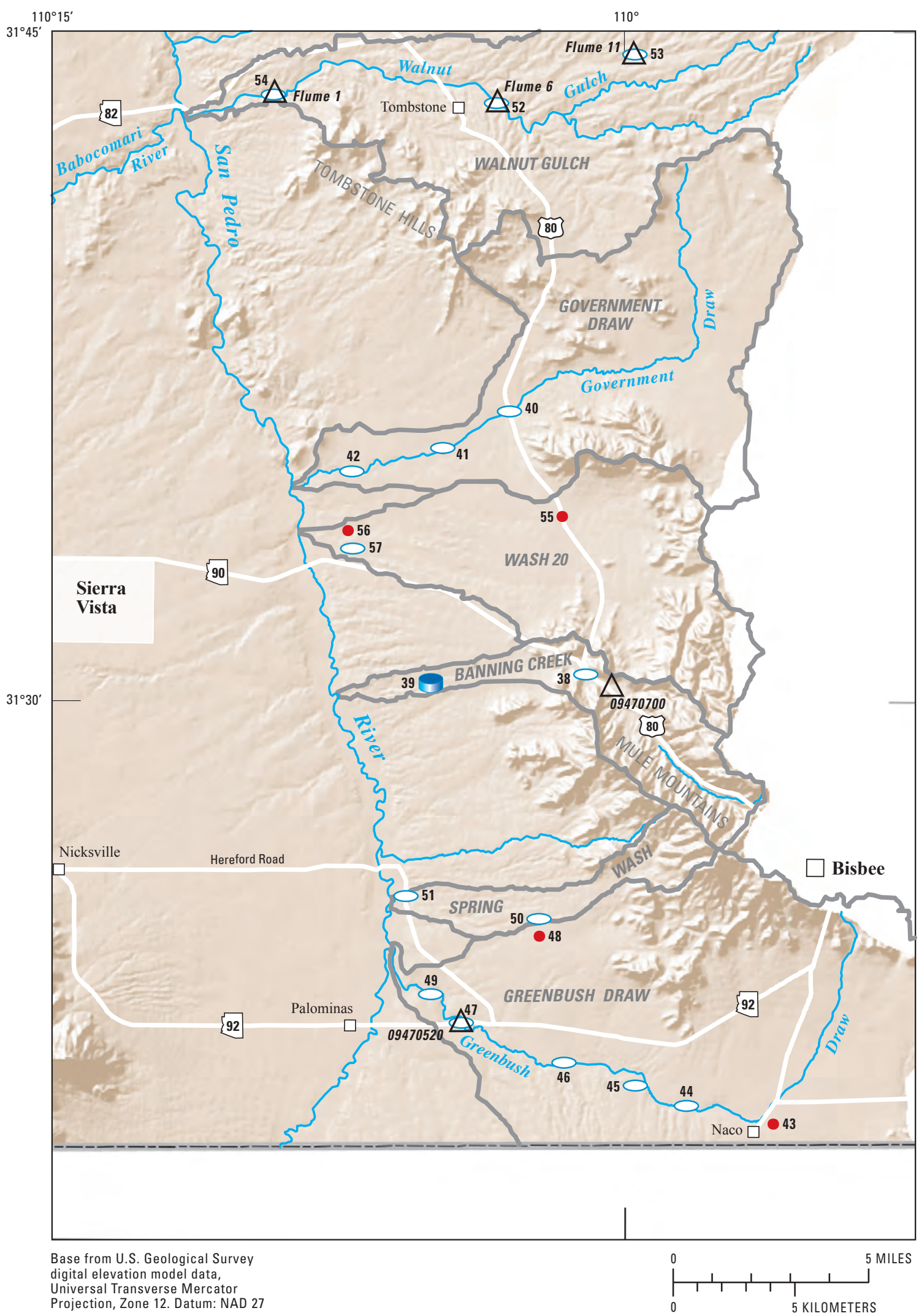

Figure 16. Duration of ephemeral streamflow at temperature-logger sites and at selected streamflow-gaging stations in the Sierra Vista Subwatershed, Arizona, east side, 2001-2002 nonmonsoon (September 20, 2001, to May $31,2002)$. For name, total-duration data, and number of flows for each site, see explanation on page 30. 
EXPLANATION FOR FIGURES 15 AND 16 (September 20, 2001, to May 31, 2002)

\author{
DRAINAGE BASIN BOUNDARY \\ TEMPERATURE LOGGER SITE-Height of cylinder indicates relative duration of ephemeral streamflow. \\ Actual minutes can be found in list below. Number identifies name of site location in list below \\ $09471310 \triangle$ STREAMFLOW-GAgING STATION \\ $52 \bigcirc$ TEMPERATURE LOGGER SITE OR STREAMFLOW-GAGING STATION WITH NO FLOW- \\ Number identifies name of site location in list below \\ 28 TEMPERATURE LOGGER SITE WITH BAD OR MISSING DATA-Number identifies name of site location in list below
}

NUMBERED LIST OF TEMPERATURE-LOGGER SITES AND STREAMFLOW-GAGING STATION WITH SELECTED FLOW DATA

\begin{tabular}{|c|c|c|c|c|c|}
\hline SLOPE WEST OF SAN PEDRO RIVER & $\begin{array}{l}\text { Duration } \\
\text { of Flow } \\
\text { in Minutes }\end{array}$ & $\begin{array}{l}\text { Number } \\
\text { of Flows }\end{array}$ & SLOPE EAST OF SAN PEDRO RIVER & $\begin{array}{l}\text { Duration } \\
\text { of Flow } \\
\text { in Minutes }\end{array}$ & $\begin{array}{l}\text { Number } \\
\text { of Flows }\end{array}$ \\
\hline 1. Ash Canyon at Stone Ridge ... & - & & 38. Banning Creek at U.S. Route $80 \ldots \ldots \ldots \ldots \ldots$ & 0 & 0 \\
\hline 2. Ash Canyon at Coronado Memorial Road ........................ & 0 & 0 & 39. Banning Creek at Misty Ray Road ............. & 240 & 1 \\
\hline 3. Brown Canyon at Coronado Memorial Road. & ○ & & 40. Government Draw at U.S. Route $80 \ldots \ldots \ldots \ldots$ & 0 & 0 \\
\hline 4. Brown Canyon south of Arizona Route $92 \ldots \ldots \ldots$ & ○ & & 41. Government Draw at Cox Ranch ............. & 0 & 0 \\
\hline 5. Carr Canyon at Arizona Route 92 . & 135 & 1 & 42. Government Draw at High Knoll Road & & \\
\hline 6. Carr Canyon at Moson Road & 825 & 1 & (extension) $\ldots \ldots \ldots \ldots \ldots \ldots \ldots$ & 0 & 0 \\
\hline 7. Coyote Wash at Arizona Route $92 \ldots .$. & ○ & & 43. Greenbush Draw at Naco Highway ............. & - & \\
\hline 8. Coyote Wash at Dake Road. & 0 & 0 & 44. Greenbush Draw east of Ladds' house ........... & 0 & 0 \\
\hline 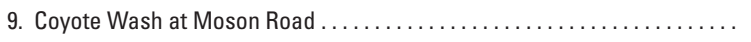 & 0 & 0 & 45. Greenbush Draw tributary, Sand Wash ........... & 0 & 0 \\
\hline 10. Garden Canyon at Fort Huachuca perimeter... & 0 & 0 & 46. Greenbush Draw at railroad bridge ............ & 0 & 0 \\
\hline 11. Garden Canyon at Arizona Route $92 \ldots$ & 810 & 2 & 47. Greenbush Draw streamflow-gaging & & \\
\hline 12. Garden Canyon at Moson Road .... & 0 & 0 & station (0947052) . . . . . . . . . . . . . & 0 & 0 \\
\hline 13. Garden Canyon at the San Pedro Riparian National Conservation Area .. & 0 & 0 & 48. Greenbush Draw tributary at Foudy Road. & - & \\
\hline 14. Graveyard Gulch, Middle Arm .. & 0 & 0 & 49. Greenbush Draw at Fox Hollow Road & 0 & 0 \\
\hline 15. Graveyard Gulch, South Arm .. & - & & 50. Spring Wash at Foudy Road. & 0 & 0 \\
\hline 16. Graveyard Gulch, North Arm ....... & 0 & 0 & 51. Spring Wash at Hereford Road ..... & 0 & 0 \\
\hline 17. Huachuca Creek at Backer Road .......... & 0 & & 52. Walnut Gulch Flume $6 \ldots \ldots \ldots \ldots \ldots$ & 0 & 0 \\
\hline 18. Huachuca Creek at gravity station "field" . & 0 & 0 & 53. Walnut Gulch Flume $11 \ldots \ldots \ldots$ & 0 & 0 \\
\hline 19. Hunter Canyon at Arizona Route 92. & 0 & 0 & 54. Walnut Gulch Flume $1 \ldots \ldots \ldots \ldots$. & 0 & 0 \\
\hline 20. Hunter Canyon at Hereford Road ....... & 0 & 0 & 55. Wash 20 at U.S. Route 80. & - & \\
\hline 21. Miller Canyon at Arizona Route $92 \ldots$ & 0 & 0 & 56. Wash 20 at High Knoll Road, North Arm . & 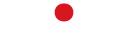 & \\
\hline 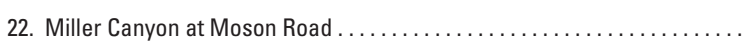 & 0 & 0 & 57. Wash 20 at High Knoll Road, South Arm & 0 & 0 \\
\hline 23. Miller Canyon at the San Pedro Riparian National Conservation Area ... & 150 & 1 & & & \\
\hline 24. Ramsey Canyon at Ramsey Canyon Road. & 0 & 0 & & & \\
\hline 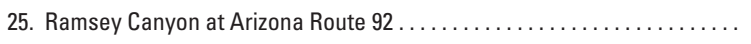 & 0 & 0 & & & \\
\hline 26. Ramsey Canyon at La Donna Road ........... & 360 & 1 & & & \\
\hline $\begin{array}{l}\text { 27. Ramsey Canyon at the San Pedro Riparian National Conservation Area .. } \\
\text { 28. Soldier Creek at Irwin Road } \ldots \ldots \ldots \ldots \ldots \ldots \ldots \ldots \ldots \ldots \ldots \ldots \ldots \ldots \ldots \ldots \ldots\end{array}$ & 120 & 1 & & & \\
\hline 29. Soldier Creek at Arizona Route 90 Bypass .. & 0 & 0 & & & \\
\hline 30. Stump Canyon at Arizona Route $92 \ldots$ & 150 & 1 & & & \\
\hline 31. Stump Canyon at Deer Canyon Trail ........ & 0 & 0 & & & \\
\hline 32. Wash 1, South Arm ........ & 0 & 0 & & & \\
\hline 33. Wash 1, Middle Arm. . & - & & & & \\
\hline 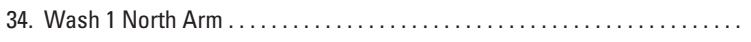 & ○ & & & & \\
\hline 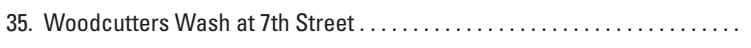 & 0 & 0 & & & \\
\hline 36. Woodcutters Wash at Arizona Route 90 Bypass .... & 45 & 1 & & & \\
\hline 37. Woodcutters Wash at Moson Road (extension)... & 0 & 1 & & & \\
\hline
\end{tabular}


This page left blank intentionally. 

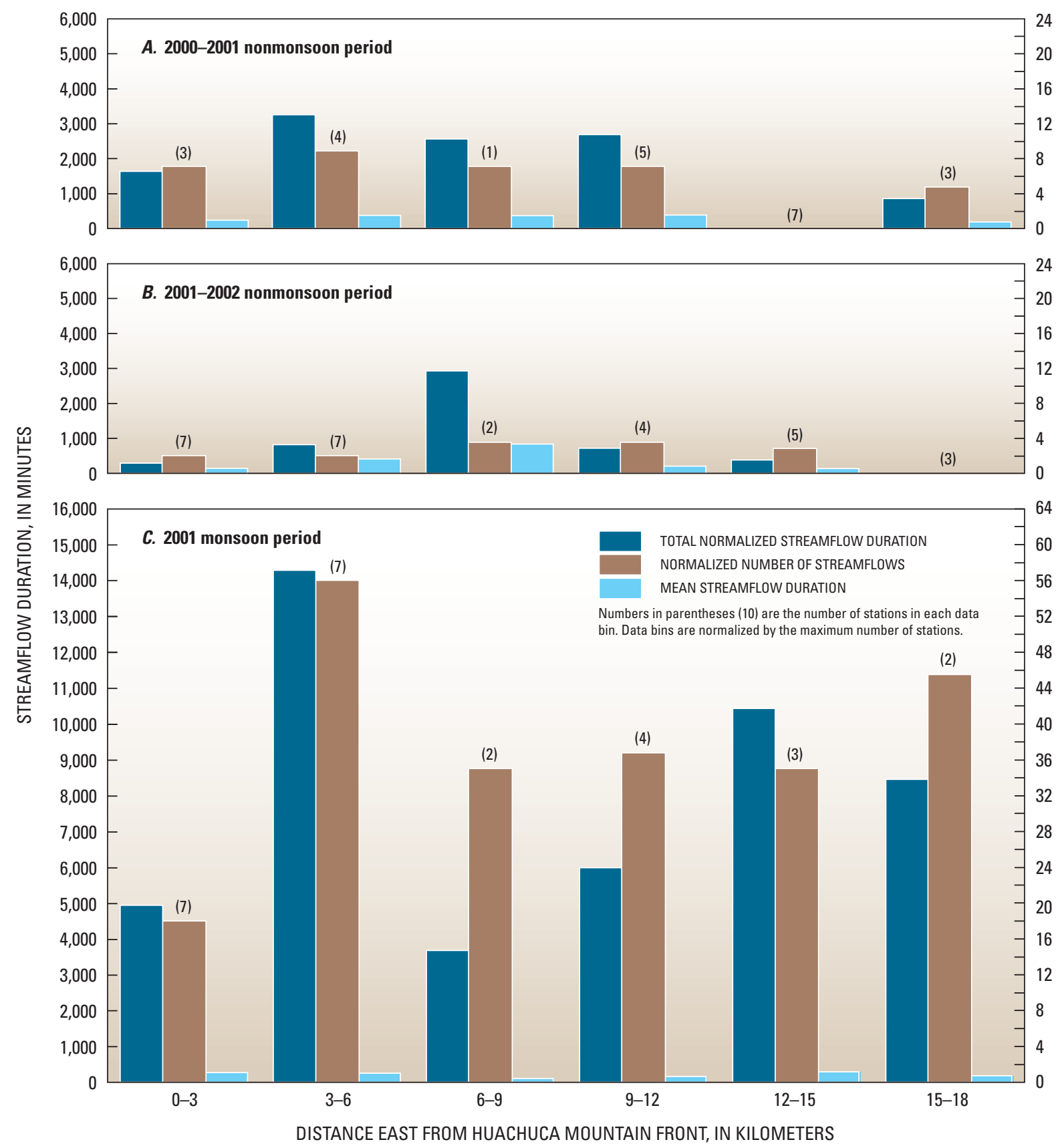

Figure 17. Total normalized streamflow duration, mean streamflow duration, and normalized number of streamflows, Sierra Vista Subwatershed, Arizona, west side, for all periods of the study. $A, 2000-2001$ nonmonsoon period (December 1, 2000, to May 31, 2001), B, 2001-2002 nonmonsoon period (September 20, 2001, to May 31, 2002), and C, 2001 monsoon period (June 1, 2001, to September 20, 2001). 
East of the river, nonmonsoon ephemeral-streamflow trended downward in both number and duration of streamflows from the mountains to the river (figs. 12, 16, 18A, B). A large total streamflow duration value of 7,232 $\mathrm{min}$ (120 h, $32 \mathrm{~min}$ ) recorded at Walnut Gulch Flume 11 (site number 53) is responsible for the bulk of the anomalous streamflow duration 10 to $15 \mathrm{~km}$ from the mountain front during the 2000-2001 nonmonsoon period (figs. 12 and 18A). Low-permeability surface bedrock in this vicinity could be responsible for the extended streamflow duration that resulted from two
January 2001 precipitation events. During the 2001-2002 nonmonsoon period, streamflow did not occur east of the river except for a single event on October 3, 2001, in Banning Creek, about $6 \mathrm{~km}$ southwest of the Mule Mountains (figs. 16 and $18 B$ ). The nonmonsoon streamflow distribution could be a function of precipitation distribution across the subwatershed during these relatively dry nonmonsoon periods rather than a reflection of the long term trend in subwatershed ephemeralstreamflow frequencies.

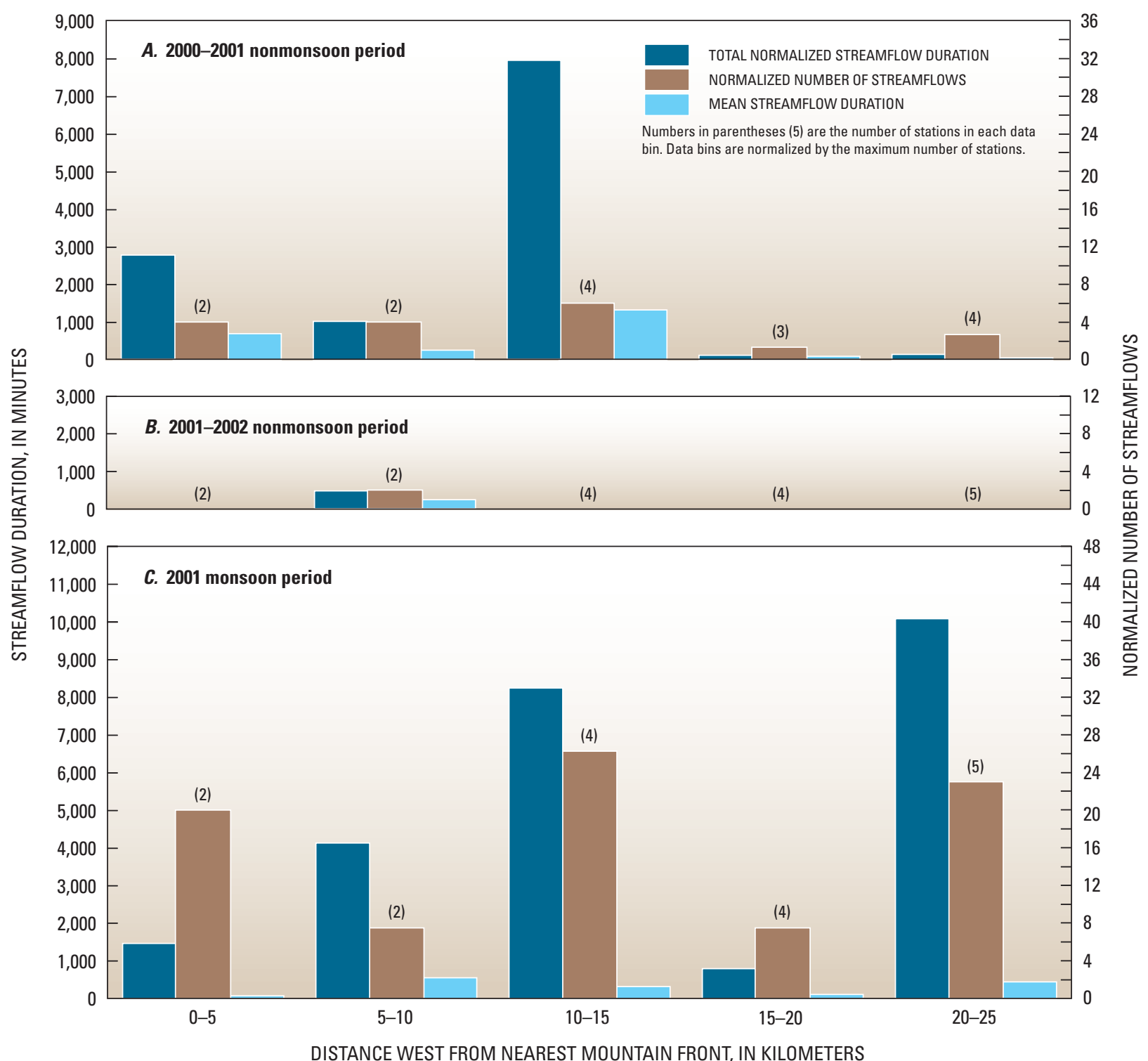

Figure 18. Total normalized streamflow duration, mean streamflow duration, and normalized number of streamflows, Sierra Vista Subwatershed, Arizona, east side, for all periods of the study. A, 2000-2001 nonmonsoon period (December 1, 2000, to May 31, 2001), B, 2001-2002 nonmonsoon period (September 20, 2001, to May 31, 2002), and C, 2001 monsoon period (June 1, 2001, to September 20, 2001). 
Streamflows during the 2001 summer monsoon (June 1 to September 19, 2001) were more evenly distributed across the subwatershed than were nonmonsoon streamflows, with only two active sites not experiencing streamflow, both on the east side. The duration of streamflow on both sides of the river generally trended higher with greater distance from the mountain fronts with the exception of one bin on each side. The number of streamflows was more variable than streamflow duration with distance from the mountain fronts on both sides of the subwatershed (figs. 13-14, 17C, 18C). As with the nonmonsoon period, the monsoon streamflowduration trends likely reflect the distribution of monsoon precipitation in 2001.

The channels monitored in urbanized areas are on the west side of the subwatershed, and therefore rural drainages used for comparison were also restricted to those found on the west side. Note that the loggers at Huachuca Canyon Wash at Backer Road and Coyote Wash at State Route 92 provided no usable data, and thus there were five active urban data points. The five urban loggers were from about 1.5 to $9.5 \mathrm{~km}$ from the Huachuca Mountain front, and averaged about $6.0 \mathrm{~km}$ distant. The rural loggers across the western part of the Sierra Vista Subwatershed ranged from 0.0 to $17.0 \mathrm{~km}$ from the Huachuca Mountain front and averaged about $7.5 \mathrm{~km}$ distant.

The total normalized streamflow duration and number of streamflows in urbanized areas were consistently greater than what occurred in rural areas across the west side of the subwatershed during the study period. Urban streamflows occurred more than 50 percent more often and were of a total streamflow duration nearly three times that of rural streamflows (fig. 19). The mean duration of rural streamflows was roughly one-half of the mean duration of urbanized streamflows during the 2000-2001 nonmonsoon and 2001 monsoon periods, and essentially the same as that for urbanized streamflows during the 2001-2002 nonmonsoon period. Precipitation in the Sierra Vista urbanized area as characterized by the Sierra Vista 30-yr average of $35.6 \mathrm{~cm}$, was less than at more rural sites. For example, the 30-yr average at Tombstone is $35.8 \mathrm{~cm}$, at Y-Lightning Ranch it is $38.8 \mathrm{~cm}$, and at Coronado Memorial Headquarters it is $53.8 \mathrm{~cm}$ (National Oceanic and Atmospheric Administration, 2004). The greater number and duration of urban streamflows were thus more likely a result of the large amount of impermeable surfaces in the urbanized area rather than functions of precipitation patterns.

\section{Temporal Streamflow Patterns}

To facilitate analysis of temporal streamflow patterns, streamflow data were normalized to the largest number of sites, $N_{L}$, found in any of the three bins (fig. 20). Data were not normalized to length of period; the 2000-2001 nonmonsoon period was 6 months, the 2001 monsoon period was 3.7 months, and the 2001-2002 nonmonsoon period was 8.3 months. As would be expected for two dry winter seasons, streamflows during the monsoon greatly exceeded streamflows during the rest of the year, accounting for 82 percent of the streamflows and 71 percent of the total streamflow duration during the entire study period. As previously noted, streamflow was detected at least once at every active logger site on the west side of the subwatershed during the 2001 monsoon, and at all but two of the active sites on the east side.

The normalized data indicate that in comparison to streamflows on the west side of the subwatershed, streamflows on the east side were (1) 50 percent more common and more than three times greater in total duration during the 2000-2001 nonmonsoon period, (2) slightly less common and shorter in total duration during the 2001 monsoon, and (3) about half as common and nearly an order of magnitude shorter in duration during the 2001-2002 nonmonsoon period (fig. 21). Although the total number of normalized streamflows in the west side of the subwatershed is only slightly greater than in the east side, the larger number of major ephemeral streams on the west side results in a larger volume of streamflow and potential recharge there. The better developed drainage system on the west side also indicates that precipitation has been more common on the west side than on the east throughout recent geologic history.

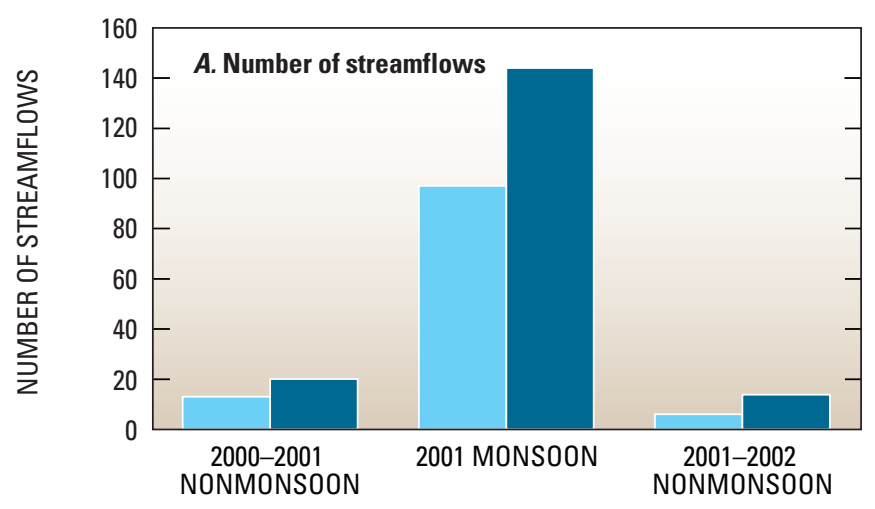

呫

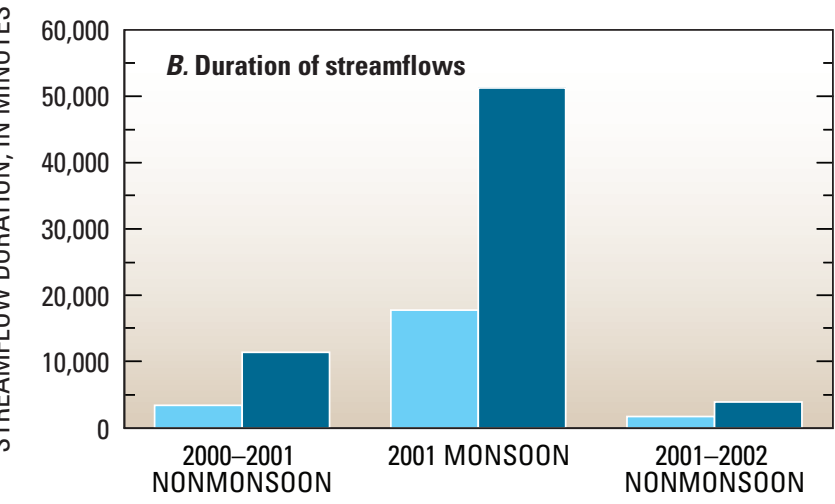

RURAL STREAMFLOW URBAN STREAMFLOW

Figure 19. Comparison of normalized rural and urban streamflows in the Sierra Vista Subwatershed, Arizona, during 2000-2001 nonmonsoon, 2001 monsoon, and 2001-2002 nonmonsoon. $A$, Number of streamflows; $B$, Duration of streamflows. 

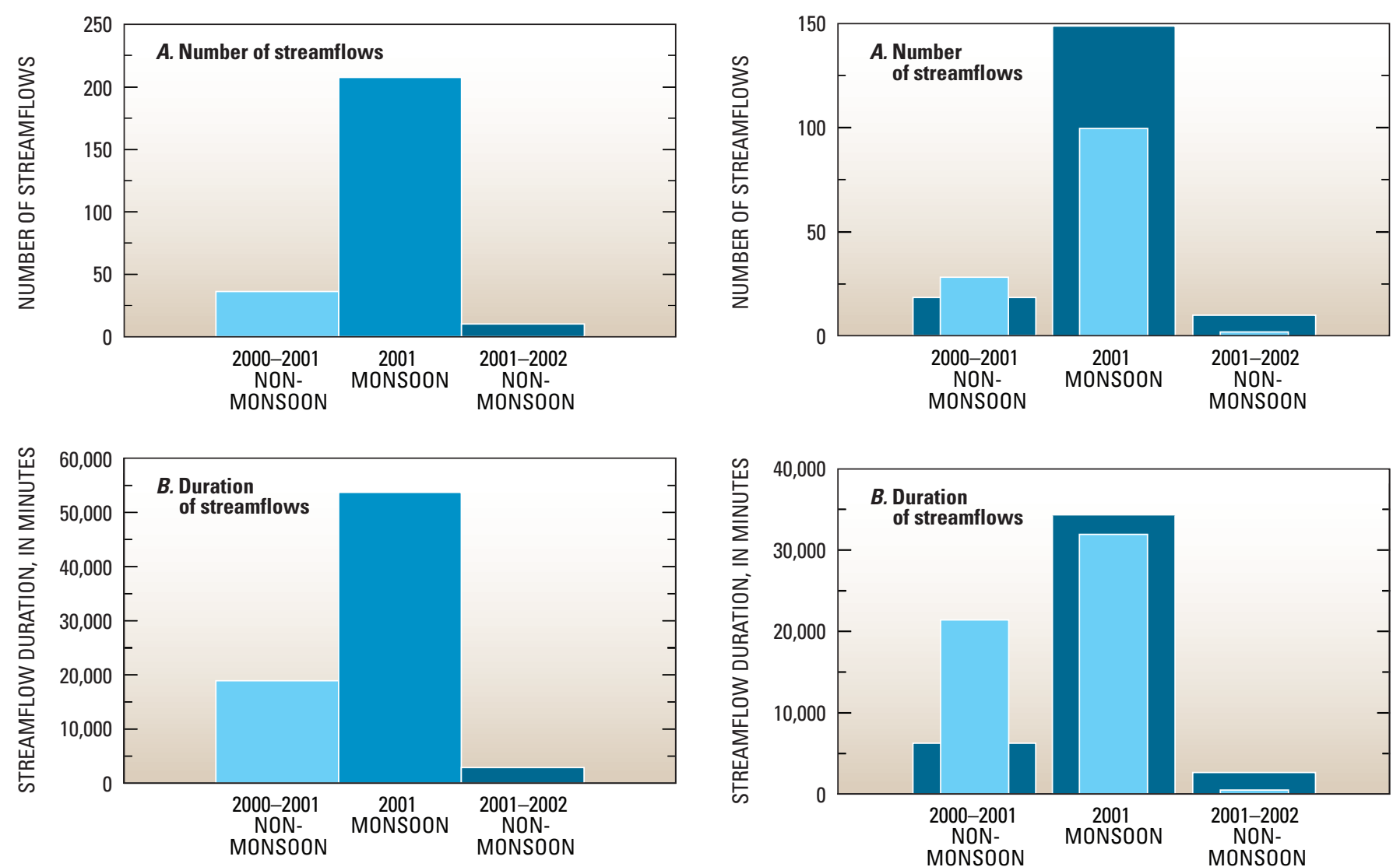

Figure 20. Comparison of all normalized streamflows across the Sierra Vista Subwatershed, Arizona, by period. $A$, Number of streamflows; $B$, Duration of streamflows.

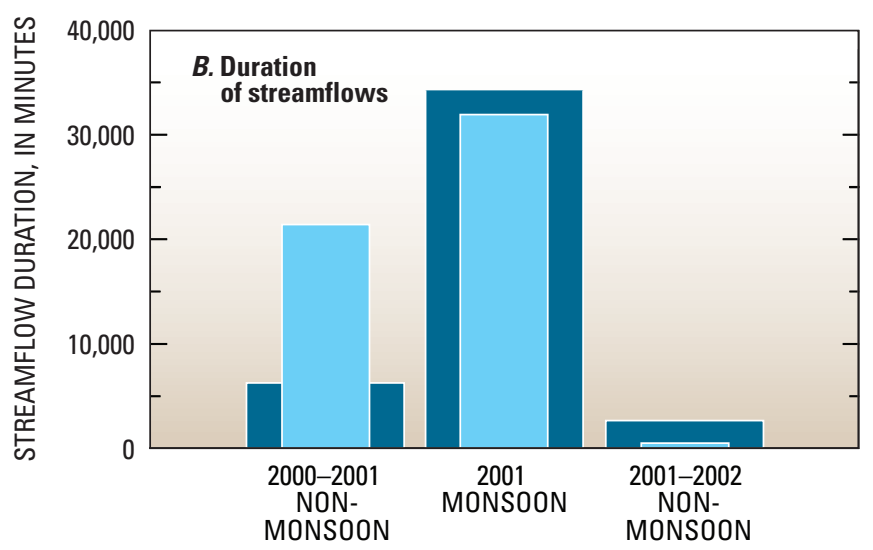

WEST SIDE

EAST SIDE

Figure 21. Comparison of normalized streamflows in the Sierra Vista Subwatershed, Arizona, west side and east side, by period. $A$, Number of sreamflows; $B$, Duration of streamflows.

All streamflows detected across the entire subwatershed during the 2000-2001 nonmonsoon period were from a January and (or) April precipitation event (figs. 15 and 20), and all streamflows detected during the 2001-2002 nonmonsoon period were from an October and (or) February event (figs. 16 and 21). Streamflows detected during the 2001 monsoon were much more varied in time and space than during the nonmonsoon periods owing to the localized and intense nature of precipitation from air mass thunderstorms typical during the summer (figs. 13 and 14; appendix).

\section{Frequency of Streamflow in Three Representative Channels}

To provide a sense of typical streamflow frequency along the length of a single wash, two examples from the west side of the subwatershed-Garden and Ramsey

Canyon Washes - and one from the east side - Greenbush Draw-are discussed below. The three washes were more densely instrumented with temperature loggers than other washes in the subwatershed because there was other existing instrumentation along their reaches, including gaging stations on all three washes, gravity stations used to measure total storage change (Garden and Ramsey Canyons), and boreholes used to estimate rates of infiltration on the basis of the location of chloride fronts (Greenbush Draw; Coes and Pool, 2005). Four temperature loggers and a streamflow-gaging station upstream from the base of the Huachuca Mountains monitored streamflow in Garden Canyon Wash and likewise in Ramsey Canyon Wash. Greenbush Draw monitoring included four temperature loggers in Greenbush Draw, two loggers in separate tributary channels, and the Greenbush Draw streamflow-gaging station at State Route 92. 


\section{Garden Canyon Wash}

The Garden Canyon Wash gaging station (09470800) is in the Huachuca Mountains about $3.5 \mathrm{~km}$ southwest of the mountain front. Temperature loggers in downstream order included GC1, about $2.5 \mathrm{~km}$ east of the Huachuca Mountain front at the southern boundary of Fort Huachuca; GC2, about $5.5 \mathrm{~km}$ east of the mountain front at State Route 92; GC3, about $11 \mathrm{~km}$ from the mountain front at Moson Road; and GC4, about $16.5 \mathrm{~km}$ from the mountain front in the San Pedro Riparian National Conservation Area (SPRNCA) near the river.
At the Garden Canyon Wash gaging station, streamflow was recorded consistently throughout the entire December 1, 2000, to May 31, 2002, monitoring period. At GC1, significant data were missing during the 2000-2001 nonmonsoon period (table 3). At GC2 and GC4, streamflow was detected once during the 2000-2001 nonmonsoon period, but no streamflow was detected at GC3 during this period. During the 2001 monsoon period, June 1, 2001, to September 19, 2001, streamflow was detected five times at GC1, eight times at GC2, and six times at GC3 and GC4. During the 2001-2002 nonmonsoon period, streamflow was detected twice at GC1. Streamflow was not detected at GC2, GC3, nor GC4.

Table 3. Dates and times of streamflows in Garden Canyon, December 1, 2000, to May 31, 2002

[Flows occurring at two or more locations are indicated by bold type. GC1, Garden Canyon at Fort Huachuca South Range; GC2, Garden Canyon at State Route 92; GC3, Garden Canyon at Moson Road; GC4, Garden Canyon near the San Pedro River. Asterisk (*) denotes time on the following day]

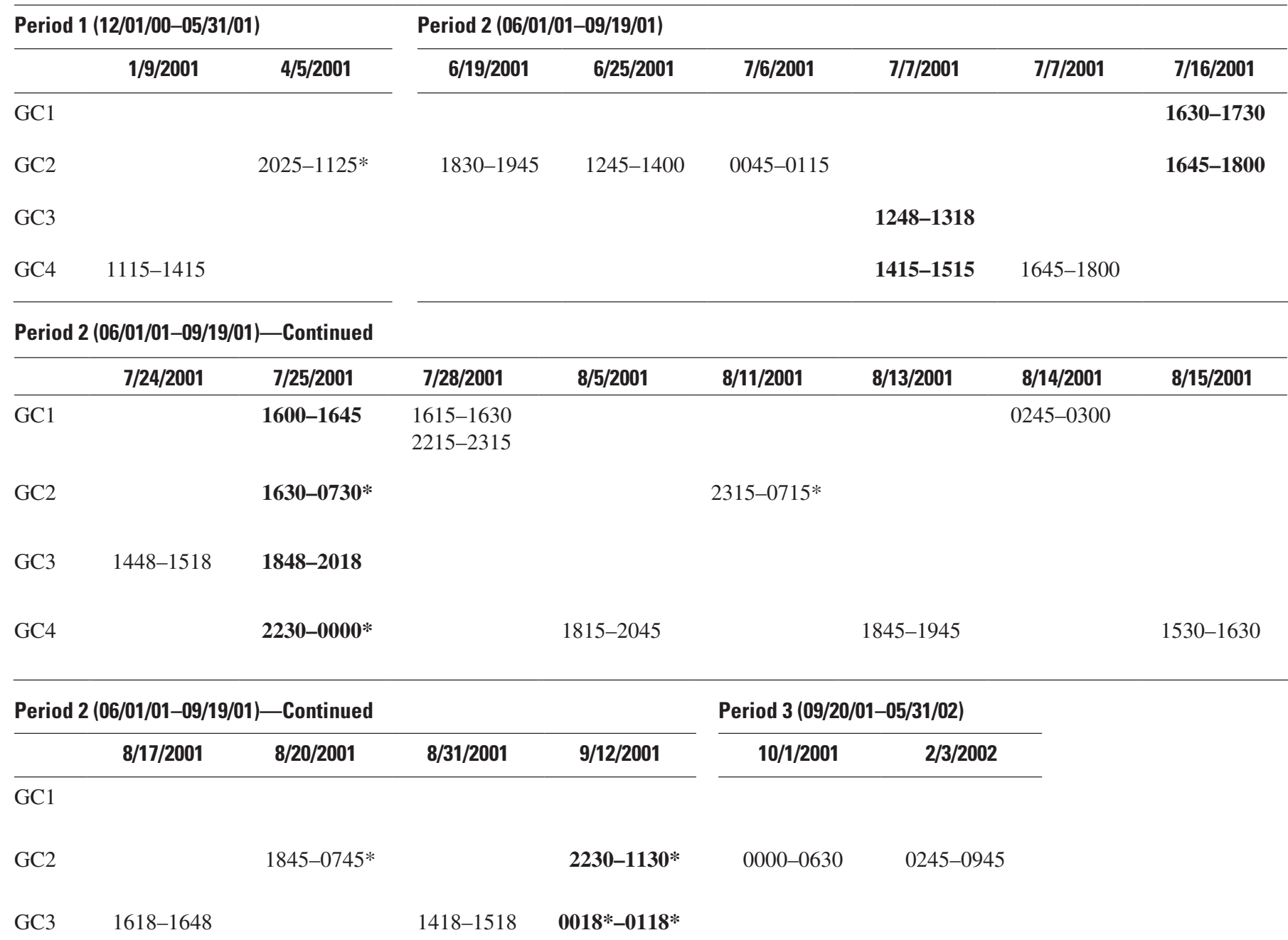

GC4 


\section{Ramsey Canyon Wash}

The Ramsey Canyon Wash gaging station (09470750) is also in the Huachuca Mountains, $2 \mathrm{~km}$ west of the mountain front. Temperature loggers in downstream order included $\mathrm{RC} 1$, at the Ramsey Road crossing of the wash and about $1 \mathrm{~km}$ east of the mountain front; RC2, about $3.5 \mathrm{~km}$ east of the mountain front at State Route 92; RC3, about $0.5 \mathrm{~km}$ east of Moson Road and $10 \mathrm{~km}$ east of the mountain front; and $\mathrm{RC} 4$, in the SPRNCA, near the river, about $15 \mathrm{~km}$ east of the mountain front.

Streamflow occurred consistently throughout the December 1, 2000, to May 31, 2002, period at the Ramsey Canyon Wash gaging station. At RC1 and $\mathrm{RC} 3$, significant amounts of data were either missing or uninterpretable during the 2000-2001 nonmonsoon period (table 4). Three streamflows were detected at RC2 and no streamflows were detected at RC4 during this period. During the 2001 monsoon period, two streamflows were detected at RC1, eight at RC2, six at RC3, and four at RC4. Like streamflows in Garden Canyon Wash, streamflows in Ramsey Canyon Wash were rare during the 2001-2002 nonmonsoon period-no streamflows were detected at $\mathrm{RC} 1$ nor $\mathrm{RC} 2$, and just one streamflow was detected at RC3 and RC4.

\section{Greenbush Draw}

Temperature loggers in downstream order along Greenbush Draw included GD1 at Naco Highway, about $8.5 \mathrm{~km}$ from the Mule Mountain front; GD2, $11.5 \mathrm{~km}$ from the mountain front; GD4, about $17.5 \mathrm{~km}$ from the mountain front; and GD6, east of Fox Hollow Road, north of State Route 92 and about $25 \mathrm{~km}$ from the mountain front. The Greenbush Draw gaging station (09470520; GDG) is at State Route 92, about $23 \mathrm{~km}$ from the Mule Mountains between GD4 and GD6. Two additional loggers are in tributary streams in the Greenbush Draw watershed. GD3, in Sand Wash, is about $0.5 \mathrm{~km}$ upstream from the mouth of Sand Wash between GD2 and GD4. GD5, in a tributary drainage at Foudy Road, is north of State Route 92 and about $5.0 \mathrm{~km}$ from the mouth of the tributary, about $0.5 \mathrm{~km}$ downstream of GD6 and about $3 \mathrm{~km}$ east from the San Pedro River.

The only Greenbush Draw site for which data were available during the 2000-2001 nonmonsoon period was GD1; two flows occurred during this time (table 5). During the 2001 monsoon and the 2001-2002 nonmonsoon, GD1 did not record interpretable data. GD2 detected streamflow 11 times during the 2001 monsoon, GD4 did not detect any streamflow, the gaging station (GDG) detected 1 streamflow, and GD6 detected four streamflows. No site in the Greenbush Draw drainage detected streamflow during the 2001-2002 nonmonsoon. GD4 did not detect any streamflow during any of the three time periods; it is possible that ranch improvements observed in this area had re-routed the main drainage so that any streamflows that did occur bypassed GD4. The two loggers on Greenbush Draw tributary washes, GD3 and GD5, were not functioning during the 2000-2001 nonmonsoon and did not record any streamflow during the 2001-2002 nonmonsoon. During the 2001 monsoon, GD3 recorded three streamflows and GD5 recorded six.

Table 4. Dates and times of streamflows in Ramsey Canyon, December 1, 2000, to May 31, 2002

[Flows occurring at two or more locations are in bold. RC1, Ramsey Canyon at Ramsey Road; RC2, Ramsey Canyon at State Route 92; RC3, Ramsey Canyon east of Moson Road; RC4, Ramsey Canyon near the San Pedro River. Asterisk (*) denotes time on the following day]

\begin{tabular}{|c|c|c|c|c|c|c|c|c|c|}
\hline \multicolumn{4}{|c|}{ Period 1 (12/01/00-05/31/01) } & \multicolumn{6}{|c|}{ Period 2 (6/01/01-09/19/01) } \\
\hline $\mathrm{RC} 1$ & missing data & missing data & missing data & & & & & $1615-1645$ & $2200-0800 *$ \\
\hline $\mathrm{RC} 2$ & bad data & bad data & bad data & $1700-1800$ & & & & $\begin{array}{l}\mathbf{1 6 1 5}-\mathbf{1 6 4 5} \\
1730-1745\end{array}$ & $2200-2345$ \\
\hline $\mathrm{RC} 4$ & & & & & & & $2000-0815 *$ & & \\
\hline \multicolumn{8}{|c|}{ Period 2 (6/01/01-09/19/01)—Continued } & \multicolumn{2}{|c|}{ Period 3 (9/20/01-05/31/02) } \\
\hline & $8 / 5 / 2001$ & 8/13/2001 & $8 / 16 / 2001$ & $8 / 17 / 2001$ & $8 / 20 / 2001$ & 9/12/2001 & 9/13/2001 & $10 / 3 / 2001$ & \\
\hline $\mathrm{RC} 1$ & & & & & & 2200-2215 & & & \\
\hline $\mathrm{RC} 4$ & 1800-2045 & & 0415-0900 & & & & $2215-2330$ & 1815-2015 & \\
\hline
\end{tabular}


Table 5. Dates and times of streamflows in Greenbush Draw, December 1, 2000, to May 31, 2002.

[Flows occuring at two or more locations are in bold. GD1, Greenbush Draw at Naco Highway; GD2, Greenbush Draw at Ladd Ranch, further east; GD4, Greenbush Draw near railroad; GDG-Greenbush Draw gaging station at State Route 92 (09470520); GD5, Greenbush Draw west of Fox Hollow Road. Asterisk (*) denotes time on the following day]

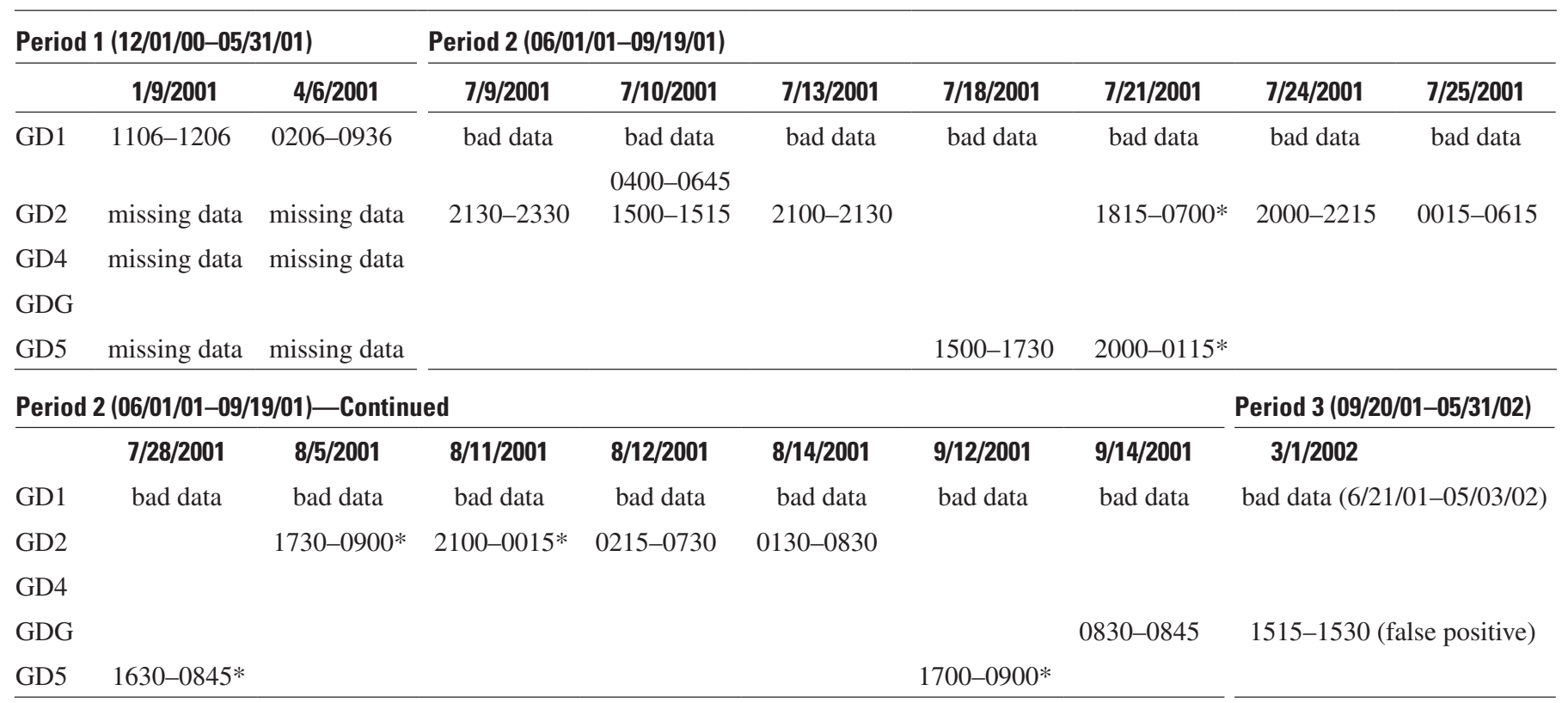

These drainage-specific data follow the overall subwatershed patterns of frequency and duration for both the nonmonsoon and monsoon periods as discussed in the section titled "Spatial Flow Patterns." In the two cases for the west part of the subwatershed, streamflow is most frequent midway between the mountains and the river during the nonmonsoon periods and close to the mountains and the river during the 2001 monsoon. During the monsoon, streamflows in Greenbush Draw followed the same pattern as streamflows in the western washes. Owing to limited data during the 2000-2001 nonmonsoon and the lack of streamflows in the 2001-2002 nonmonsoon, however, streamflow data during nonmonsoon periods was inconclusive. The channel-specific data also highlight the fact that streamflow occurs at least once a year along most reaches of the ephemeral-stream channels in the Sierra Vista Subwatershed, and that during the 18-month monitoring period, most instances of streamflow occurred during the summer monsoon.

\section{Variability of Streamflow in Three Representative Channels}

Of the 23 events detected along Garden Canyon Wash, 19 were detected at only 1 of the 4 sites ( 83 percent), 3 were detected at 2 sites (13 percent), and only 1, on July 25, 2001, was detected at all 4 temperature logger sites (4 percent; table 3). The Ramsey Canyon Wash data (table 4) are similar to the Garden Canyon Wash data. Of 18 streamflows detected at the 4 logger sites, 12 were detected at only 1 site (67 percent), 5 were detected at 2 sites ( 28 percent) and only 1, on August 5, 2001, was detected at 3 sites (6 percent). No single streamflow was detected at all 4 sites.

On the east side of the subwatershed, the data from Greenbush Draw were even more variable (table 5). Seventeen events were detected by the 4 temperature loggers and the 1 gaging station installed along the drainage. Sixteen of the 17 events were detected at only 1 of the 5 sites (94 percent). The remaining event, on July 21, 2001, was detected at 2 sites ( 6 percent), GD2 and GD5. These were the farthest upstream and downstream sites, respectively, that were functioning at this time. Streamflow was not recorded at the intervening sites, GD4 and GDG, which indicates that these were temporally coincident yet isolated streamflow events. Likewise, whereas 6 of the 9 streamflows that occurred at the Greenbush Draw tributary sites (GD3 and GD5) were coincident with other Greenbush Draw streamflows, none were coincident with streamflows recorded at loggers downstream from the mouth of either tributary. Thus, these too were isolated streamflow events.

Streamflow distribution in the ephemeral-stream channels of the Sierra Vista Subwatershed of the Upper San Pedro Basin was much less consistent than might be expected. The majority of streamflows were recorded at a single location along the channel, and only one of the three channels reviewed in detail - Garden Canyon - had a streamflow that was detected along its entire length. In general, it appears that rather than originating in the mountains and continuing 
out some distance into the basin, ephemeral streamflow in the subwatershed is localized in origin in all but the heaviest and (or) widespread precipitation events. Ephemeral-stream channels of the Sierra Vista Subwatershed thus appear to serve more frequently as focal points for local runoff_-and thus recharge - than as a means of riverward conveyance.

\section{Summary and Conclusions}

Investigation of the duration and frequency of ephemeral streamflows of less than 24-h duration in the Sierra Vista Subwatershed of the Upper San Pedro Basin indicates that ephemeral streamflow is well distributed across the subwatershed, with most sites having at least one incidence of streamflow every year. Streamflows during the nonmonsoon period on the west side of the subwatershed were most common midway between the river and the mountains. On the east side, nonmonsoon streamflows were somewhat more common closer to the mountain front; during the 2001 summer monsoon, the pattern of streamflow frequency and duration across the subwatershed generally increased farther from, rather than closer to, the mountain fronts. Streamflow distribution thus appears to be a function of the distribution of precipitation. The exception is where streamflow occurs in urbanized areas: streamflows were over 50 percent more frequent and nearly three times longer in overall duration in urbanized areas of the subwatershed than they were in rural areas. Washes on the east side of the subwatershed appear to flow about as often as those on the west. Because there are fewer major washes on the east side of the subwatershed, however, the volume of precipitation available for channel infiltration is likely much lower on the east side than on the west.

Monsoon streamflows are much more varied in time and space than are nonmonsoon streamflows, a result of the localized and intense nature of precipitation from the air mass thunderstorms typical during the summer. All nonmonsoon streamflows during the study period were due to just four precipitation events, whereas during the single monsoon period, over 30 individual streamflow events occurred in just the Garden Canyon, Ramsey Canyon, and Greenbush Draw channels alone.

Most streamflows in any one channel of the subwatershed at any time of the year are localized events, beginning and ending within a limited reach of the stream channel; it is uncommon for streamflows of less than 24-h duration that begin in the mountains to reach the river as streamflow. Ephemeral-stream channels of the Sierra Vista Subwatershed appear to serve more commonly as focal points for local runoff than as a means of conveyance of drainage basin runoff to the San Pedro River. Thus, the location of recharge in most years is driven by the location of localized precipitation events across the subwatershed and possibly could be approximated using a precipitation-gage network.
A second and longer multiyear study using the electrical resistance sensors pioneered by Blasch and others (2002) would help to refine many of the conclusions found in this report. In particular, such a study would determine whether the spatial streamflow patterns observed in the ephemeral-stream channels of this study are consistent from year to year, or vary owing to the vagaries of precipitation or other factors. A more comprehensive network of loggers immediately downstream from urbanized areas would provide a more precise value for the amount of enhanced discharge (and potential recharge) that occurs owing to the large areas of impervious surface found in the urbanized Sierra Vista area. The addition of even a modest subwatershed-wide precipitation-gage network would be of much value in establishing a correlation between precipitation events and localized streamflow events. A longer study would also be more likely to include a nonmonsoon period of average or above average precipitation, which was not available for this study.

\section{References Cited}

Adams, D., and Comrie, A.C. 1999, The North American Monsoon: Bulletin of the American Meteorological Society, v. 78, p. 2197-2213.

Allander, K.K., 2003, Trout Creek-evaluating ground-water and surface water exchange along an alpine stream, Lake Tahoe, California, in Stonestrom, D.A and Constantz, J., eds., Heat as a tool for studying the movement of ground water near streams: U.S. Geological Survey Circular 1260, p. 35-45.

Arizona Department of Water Resources, 2005, Upper San Pedro Basin active management area review report, v.p.

Bartolino, J.R., 2003, The Rio Grande-competing demands for a desert river, in Stonestrom, D.A and Constantz, J., eds., Heat as a tool for studying the movement of ground water near streams: U.S. Geological Survey Circular 1260, p. $8-16$.

Blasch, K.W., Ferré, T.P.A., Christensen, A.H. and Hoffmann, J.P., 2002, New field method to determine streamflow timing using electrical resistance sensors: Vadose Zone Journal, v. 1, p. 289-299.

Blasch, K. W., Ferré, T.P.A., and Hoffmann, J. P., 2004, A statistical technique for interpreting streamflow timing using streambed sediment thermographs: Vadose Zone Journal, v. 3, p. 936-946.

Brown, S.G., Davidson, E.S., Kister, L.R., and Thomsen, B.W., 1966, Water resources of Fort Huachuca Military Reservation, southeastern Arizona: U.S. Geological Survey Water-Supply Paper 1819-D, p. D1-D57. 
Carslaw, H.S., and Jaeger, J.C., 1959, Conduction of Heat in Solids ( $2^{\text {nd }}$ ed.): New York, Oxford University Press, 510 p.

Coes, A. and Pool, D.R., 2005, Ephemeral-Stream channel and basin-floor infiltration and recharge in the Sierra Vista Subwatershed of the Upper San Pedro Basin, Southeastern Arizona: U.S. Geological Survey Open-File Report 2005-1023, 63 p.

Conlon, T., Lee, K., and Risley, J, 2003, Heat tracing in streams in the central Willamette Basin, Oregon, in Stonestrom, D.A. and Constantz, J., eds., Heat as a tool for studying the movement of ground water near streams: U.S. Geological Survey Circular 1260, p. 29-34.

Constantz, J., 1998, Interaction between stream temperature, streamflow, and groundwater exchanges in alpine streams: Water Resources Research, v. 34, p. 1609-1615.

Constantz, J., Cox, M. H., Sarma, L., and Mendez, G., 2003, The Santa Clara River-the last natural river of Los Angeles, in Stonestrom, D.A. and Constantz, J., eds., Heat as a tool for studying the movement of ground water near streams: U.S. Geological Survey Circular 1260, p. 17-27.

Constantz, J., Stewart, A.E., Niswonger, R., and Sarma, L., 2002, Analysis of temperature profiles for investigating stream losses beneath ephemeral channels: Water Resources Research, v. 38, p. 52-1 through 52-13.

Constantz, J. and Stonestrom, D., 2003, Heat as a tracer of water movement near streams, in Stonestrom, D.A. and Constantz, J., eds., Heat as a tool for studying the movement of ground water near streams: U.S. Geological Survey Circular 1260, p. 1-6.

Constantz, J., Stonestrom, D., Stewart, A.E., Niswonger, R., and Smith, T.R., 2001, Analysis of streambed temperatures in ephemeral-stream channels to determine streamflow frequency and duration: Water Resources Research, v. 37, p. 329-340.

Constantz, J., and Thomas, C.L., 1996, The use of streambed temperature profiles to estimate depth, duration, and rate of percolation beneath arroyos: Water Resources Research, v. 32 , p. $3597-3602$.

Constantz, J., and Thomas, C.L., 1997, Streambed temperature profiles as indicators of percolation characteristics beneath arroyos in the Middle Rio Grande Basin, USA: Hydrologic Processes v. 11, p. 1621-1634.

Constantz, J., Thomas, C.L., and Zellweger, G., 1994, The influence of diurnal stream temperature variations on streamflow and recharge: Water Resources Research,v. 30, p. 3253-3264.
Constantz, J., Tyler, S.W., and Kwicklis, E., 2003, Temperature-profile methods for estimating percolation rates in arid environments: Vadose Zone Journal, v. 2, p. $12-24$.

Dunne, T. and Leopold, L. B., 1978, Precipitation, chap. 2 of Water in Environmental Planning: W. H. Freeman and Company, New York, p. 35-82.

Gungle, B., 2003, Estimation of ephemeral streamflow duration using temperature methods in the Upper San Pedro Basin, Arizona, in Proceedings of First Interagency Conference on Research in Watersheds, October 27-30, 2003, Benson, Arizona, p. 146-151.

Hereford, R., 1993, Entrenchment and widening of the Upper San Pedro River, Arizona: Geologic Society of America, Special Paper 282, 46 p.

Hillel, D., 1998, Soil temperature and heat flow, chap. 12 of Environmental Soil Physics, (2 ${ }^{\text {nd }}$ ed.): Academic Press, San Diego, CA, p. 309-339.

Hoffmann, J.P., Blasch, K.W., Ferré, P.A., 2003, Combined use of heat and soil-water content to determine stream/ ground-water exchanges, Rillito Creek, Tucson, Arizona, in Stonestrom, D.A and Constantz, J., eds., Heat as a tool for studying the movement of ground water near streams: U.S. Geological Survey Circular 1260, p. 47-55.

Jaynes, D.B., 1990, Temperature variation effects on field measured infiltration: Soil Science Society of America Journal, v. 54, p. 305-312.

Jury, W.A., Gardner, W.R., and Gardner, W.H., 1991, The soil thermal regime, chap. 5 of Soil Physics (5th ed.): John Wiley and Sons, Inc., New York, p. 159-195.

Lapham, W.W., 1989, Use of temperature profiles beneath streams to determine rates of vertical ground-water flow and vertical hydraulic conductivity: U.S. Geological Survey Water-Supply Paper 2337, 34 p.

Lawler, D., 2002, Using streambed temperature sensors to monitor flow events in the San PedroRiver, southeastern Arizona and north-central Sonora, Mexico: Tucson, Ariz., University of Arizona, unpublished M.S. thesis, 68 p.

National Oceanic and Atmospheric Administration, 2004, National Climate Data Center, U.S. Climate Normals, accessed March 5, 2004, at http://www5.ncdc.noaa.gov/cgibin/climatenormals/climatenormals.pl?directive $=$ prod select $2 \&$ prodtype $=$ CLIM20\&subrnum $=$

Pool, D.R., and Coes, A. L., 1999, Hydrogeologic investigations of the Sierra Vista subwatershed of the Upper San Pedro Basin, Cochise County, southeastern Arizona: U. S. Geological Survey Water-Resources Investigations Report 99-4197, 41 p. 
Prudic, D.E., Niswonger, R.G., Wood, J.L., and Henkelman, K.K, 2003, Trout Creek-estimating flow duration and seepage losses along an intermittent stream tributary to the Humboldt River, Lander and Humboldt Counties, Nevada, in Stonestrom, D.A and Constantz, J., eds., Heat as a tool for studying the movement of ground water near streams: U.S. Geological Survey Circular 1260, p. 57-71.

Ronan, A.D., Prudic D.E., Thodal, C.E., and Constantz, J., 1998, Field study and simulation of diurnal temperature effects on infiltration and variably saturated flow beneath an ephemeral stream: Water Resources Research, v. 34, p. 2137-2153.

Rorabaugh, M. I., 1954, Streambed percolation in development of water supplies: U.S. Geological Survey Groundwater Notes on Hydraulics No. 25, 13 p.

Serway, R.A., 1996, Thermodynamics, Part III of Physics for scientists and engineers: Saunders College Publishing, San Francisco.

Silliman, S.E., and Booth, D.F., 1993, Analysis of time-series measurements of sediments temperature for identification of gaining vs. losing portions of Juday Creek, Indiana: Journal of Hydrology, v. 146, p. 131-148.

Stewart, A.E., 2003, Temperature based estimates of streamflow patterns and seepage losses in ephemeral-stream channels: Palo Alto, Cal., Stanford University, unpublished Ph.D dissertation, $248 \mathrm{p}$.

Taniguchi, M. and Sharma, M.L., 1990, Solute and heat transport experiments for estimating recharge rate: Journal of Hydrology, v. 119, p. 57-69.

U.S. Census Bureau, 2004, Geographic Comparison Table, GCT-PH1, Population, Housing Units, Area and Density: 2000, Census 2000 Summary File 1 (SF 1) 100-Percent Data, accessed April 2, 2004 at http://factfinder.census. gov/servlet/MetadataBrowserServlet?type $=$ dataset\&id=DE C_2000_SF1_U\&_lang=en

U.S. Environmental Protection Agency, 2005, Upper San Pedro Watershed Geodata, accessed June 1, 2005, at http://www.epa.gov/nerlesd1/land-sci/san_ pedro/ geodata/ land_cover_1997.html 
This page left blank intentionally. 


\section{Appendix}


[When over 40 percent of the data at a given location are bad or missing, the data are not included in the data set used for analysis for that period and the values are shown in red; locations in italics did not provide any useful data throughout the entire monitoring period; UTM-E: Universal Transverse Mercator, East, Zone 12; UTM-N: Universal Transverse Mercator, North, Zone 12; SPRNCA: San Pedro Riparian National Conservation Area]

\begin{tabular}{|c|c|c|c|c|c|c|c|c|c|}
\hline \multirow[b]{2}{*}{ Temperature logger location } & \multirow{2}{*}{$\begin{array}{l}\text { Logger serial } \\
\text { number or } \\
\text { gaging-station } \\
\text { number }\end{array}$} & \multirow[b]{2}{*}{ UTM-E } & \multirow[b]{2}{*}{ UTM-N } & \multirow[b]{2}{*}{$\begin{array}{l}\text { Subwatershed } \\
\text { side }\end{array}$} & \multirow{2}{*}{$\begin{array}{l}\text { Distance to } \\
\text { mountain front } \\
\text { (kilometers) }\end{array}$} & \multicolumn{4}{|c|}{$\begin{array}{c}\text { December 1, 2000, to May 31, } 2002 \text { (entire study period) } \\
\text { Total time (minutes): } 787635\end{array}$} \\
\hline & & & & & & $\begin{array}{l}\text { Number } \\
\text { of flows }\end{array}$ & $\begin{array}{l}\text { Flow duration } \\
\text { (minutes) }\end{array}$ & $\begin{array}{l}\text { Bad or missing data } \\
\text { (minutes) }\end{array}$ & $\begin{array}{l}\text { No-flow duration } \\
\text { (minutes) }\end{array}$ \\
\hline Ash at Coronado Memorial Road & 374907 & 575468 & 3471417 & $\mathrm{~W}$ & 1.0 & 4 & 1125 & 0 & 786510 \\
\hline Ash at Stone Ridge Road & 377819 & 573786 & 3472174 & $W$ & 0.0 & 0 & 0 & 787635 & 0 \\
\hline Brown south of State Route 92 & 374964 & 587143 & 3510923 & $W$ & 4.0 & 4 & 975 & 715020 & 71640 \\
\hline Brown at Coronado Memorial Road & 377790 & 575457 & 3470074 & W & 0.0 & 2 & 630 & 363315 & 423690 \\
\hline Carr at Moson Road & 377810 & 577045 & 3482620 & $\mathrm{~W}$ & 9.0 & 6 & 1125 & 173295 & 613215 \\
\hline Carr at State Route 92 & 374875 & 570646 & 3479835 & $\mathrm{~W}$ & 2.0 & 4 & 1800 & 262065 & 523770 \\
\hline Coyote at Dake Road & 377791 & 575363 & 3492599 & $\mathrm{~W}$ & 13.5 & 8 & 2760 & 0 & 784875 \\
\hline Coyote at Moson Road & 375014 & 576974 & 3495068 & W & 16.0 & 1 & 15 & 122580 & 665040 \\
\hline Coyote at State Route 92 & 375008 & 570600 & 3489810 & $W$ & 8.0 & 0 & 0 & 787635 & 0 \\
\hline Garden at fort perimeter & 375011 & 567973 & 3484602 & W & 2.5 & 5 & 195 & 257955 & 529485 \\
\hline Garden at Moson Road & 377823 & 577019 & 3486848 & $\mathrm{~W}$ & 11.0 & 6 & 300 & 0 & 787335 \\
\hline Garden at State Route 92 & 377805 & 570649 & 3486091 & $\mathrm{~W}$ & 5.5 & 11 & 4905 & 0 & 782730 \\
\hline Garden at the SPRNCA & 374913 & 581599 & 3489438 & $\mathrm{~W}$ & 16.5 & 7 & 675 & 0 & 786960 \\
\hline Graveyard: middle arm & 374929 & 570531 & 3495223 & W & 11.0 & 4 & 345 & 0 & 787290 \\
\hline Graveyard: north arm & 377812 & 571973 & 3497533 & $\mathrm{~W}$ & 13.0 & 0 & 0 & 216405 & 571230 \\
\hline Graveyard: south arm & 374917 & 571185 & 3494485 & W & 11.0 & 0 & 0 & 434430 & 353205 \\
\hline Huachuca at Backer ${ }^{l}$ & 377826 & 560026 & 3491136 & $W$ & 0.0 & 15 & 14310 & 103125 & 670200 \\
\hline Huachuca Ft. Huachuca west range & 375005 & 560875 & 3495497 & $\mathrm{~W}$ & 3.5 & 10 & 930 & 0 & 786705 \\
\hline Hunter at Hereford Road & 377811 & 575562 & 3478262 & W & 5.0 & 12 & 2205 & 0 & 785430 \\
\hline Hunter at State Route 92 & 374860 & 572147 & 3474619 & $\mathrm{~W}$ & 0.0 & 1 & 285 & 0 & 787350 \\
\hline Miller at Moson Road & 377797 & 577051 & 3480770 & W & 7.5 & 6 & 1110 & 0 & 786525 \\
\hline Miller at State Route 92 & 377806 & 572217 & 3477133 & $\mathrm{~W}$ & 1.5 & 3 & 990 & 196208 & 590437 \\
\hline Miller at the SPRNCA & 374919 & 582624 & 3484892 & $\mathrm{~W}$ & 14.5 & 4 & 600 & 0 & 787035 \\
\hline Ramsey at La Donna Road & 375006 & 577432 & 3484132 & W & 10.0 & 10 & 3045 & 0 & 784590 \\
\hline Ramsey at Ramsey Canyon Road & 377809 & 568382 & 3481436 & $\mathrm{~W}$ & 1.0 & 3 & 735 & 252495 & 534405 \\
\hline Ramsey at State Route 92 & 377814 & 570623 & 3482449 & W & 3.5 & 8 & 1200 & 252614 & 533821 \\
\hline Ramsey at the SPRNCA & 377824 & 582146 & 3485966 & $\mathrm{~W}$ & 15.0 & 5 & 1380 & 0 & 786255 \\
\hline Soldier at Irwin Road & 395921 & 563822 & 3490323 & $W$ & 2.5 & 0 & 0 & 683175 & 104460 \\
\hline Soldier at State Route 90 Bypass & 375012 & 566151 & 3492758 & W & 6.0 & 3 & 165 & 242565 & 544905 \\
\hline Stump at Deer Canyon Trail & 377794 & 576688 & 3474742 & $\mathrm{~W}$ & 4.0 & 2 & 225 & 154635 & 632775 \\
\hline Stump at State Route 92 & 374934 & 572350 & 3473913 & $\mathrm{~W}$ & 0.0 & 6 & 2640 & 331140 & 453855 \\
\hline
\end{tabular}


Temperature-logger data, by location and period-Continued

\begin{tabular}{|c|c|c|c|c|c|c|c|c|c|}
\hline \multirow[b]{2}{*}{ Temperature logger location } & \multirow{2}{*}{$\begin{array}{c}\text { Logger serial } \\
\text { number or } \\
\text { gaging-station } \\
\text { number }\end{array}$} & \multirow[b]{2}{*}{ UTM-E } & \multirow[b]{2}{*}{ UTM-N } & \multirow[b]{2}{*}{$\begin{array}{l}\text { Subwatershed } \\
\text { side }\end{array}$} & \multirow{2}{*}{$\begin{array}{l}\text { Distance to } \\
\text { mountain front } \\
\text { (kilometers) }\end{array}$} & \multicolumn{4}{|c|}{$\begin{array}{c}\text { December 1, 2000, to May 31, } 2002 \text { (entire study period) } \\
\text { Total time (minutes): } 787635\end{array}$} \\
\hline & & & & & & $\begin{array}{l}\text { Number } \\
\text { of flows }\end{array}$ & $\begin{array}{l}\text { Flow duration } \\
\text { (minutes) }\end{array}$ & $\begin{array}{l}\text { Bad or missing data } \\
\text { (minutes) }\end{array}$ & $\begin{array}{l}\text { No-flow duration } \\
\text { (minutes) }\end{array}$ \\
\hline Wash 1: middle arm & 374905 & 571513 & 3498773 & $\mathrm{~W}$ & 14.5 & 3 & 330 & 411030 & 376275 \\
\hline Wash 1: north arm & 374926 & 570445 & 3501312 & $\mathrm{~W}$ & 14.5 & 0 & 0 & 547515 & 240120 \\
\hline Wash 1: south arm & 374904 & 571156 & 3499849 & $\mathrm{~W}$ & 13.5 & 0 & 0 & 216240 & 571395 \\
\hline Woodcutters at 7 th Street & 375010 & 567145 & 3489464 & $\mathrm{~W}$ & 4.5 & 17 & 7290 & 0 & 780345 \\
\hline Woodcutters at Moson Road extension & 377788 & 576871 & 3496422 & $\mathrm{w}$ & 17.0 & 8 & 2100 & 0 & 785535 \\
\hline Woodcutters at State Route 90 Bypass & 377793 & 570592 & 3492064 & $\mathrm{~W}$ & 9.5 & 8 & 2025 & 24510 & 761100 \\
\hline Banning at Misty Ray Road & 377796 & 587010 & 3485981 & E & 6.0 & 3 & 990 & 262065 & 524685 \\
\hline Banning at State Route 80 & 377822 & 593387 & 3486458 & E & 0.0 & 2 & 165 & 115170 & 672300 \\
\hline Government at Cox Ranch & 374910 & 587476 & 3495798 & E & 19.5 & 3 & 225 & 0 & 787410 \\
\hline Government at High Knoll Road & 374877 & 583559 & 3494870 & E & 24.0 & 9 & 5310 & 0 & 782325 \\
\hline Government at State Route 80 & 377799 & 590175 & 3497342 & E & 16.5 & 4 & 495 & 0 & 787140 \\
\hline Greenbush at Fox Hollow Road & 377820 & 586866 & 3473143 & E & 25.0 & 4 & 2400 & 298785 & 486450 \\
\hline Greenbush at Naco Highway & 377815 & 601336 & 3467873 & E & 8.5 & 6 & 510 & 455295 & 331830 \\
\hline Greenbush at railroad & 377825 & 583335 & 3497578 & E & 17.5 & 0 & 0 & 298950 & 488685 \\
\hline Greenbush east of Ladd's house & 375015 & 597680 & 3468580 & E & 11.5 & 11 & 3450 & 298860 & 485325 \\
\hline Greenbush at Foudy Road (tributary) & 374866 & 591544 & 3475585 & E & NA & 6 & 1845 & 477840 & 307950 \\
\hline Greenbush-Sand Wash (tributary) & 377818 & 595612 & 3469331 & E & NA & 3 & 1035 & 298890 & 487710 \\
\hline Greenbush Draw gaging station & 9470520 & 588246 & 3472150 & E & 23.0 & 1 & 15 & 0 & 787605 \\
\hline Spring at Foudy Road & 374854 & 591543 & 3476262 & E & 4.0 & 6 & 420 & 0 & 787215 \\
\hline Spring at Hereford Road & 374925 & 586069 & 3477241 & E & 9.5 & 1 & 900 & 0 & 786735 \\
\hline Wash 20 at High Knoll Road: north & 374923 & 583516 & 3492363 & E & 9.0 & 2 & 405 & 360255 & 426975 \\
\hline Wash 20 at High Knoll Road: south & 374927 & 583731 & 3491601 & E & 9.0 & 6 & 2280 & 0 & 785355 \\
\hline Wash 20 at State Route 80 & 374868 & 592387 & 3492999 & E & 4.0 & 4 & 1470 & 291090 & 495075 \\
\hline Walnut Gulch flume 1 & 1 & 580271 & 3510740 & E & 24.0 & 5 & 615 & 0 & 787020 \\
\hline Walnut Gulch flume 11 (tributary) & 11 & 595258 & 3512230 & E & NA & 6 & 7478 & 0 & 780157 \\
\hline Walnut Gulch flume 6 & 6 & 589524 & 3510221 & $\mathrm{E}$ & 16.5 & 0 & 0 & 0 & 787635 \\
\hline Babocomari (lower) gaging station & 9471400 & 573309 & 3507475 & $\mathrm{~W}$ & NA & 3 & 699810 & 0 & 87825 \\
\hline Babocomari (upper) gaging station & 9471380 & 556701 & 3499814 & $\mathrm{~W}$ & NA & 3 & 699810 & 0 & 87825 \\
\hline Garden Canyon gaging station & 9470800 & 562009 & 3482184 & $\mathrm{~W}$ & 0.0 & 3 & 699810 & 0 & 87825 \\
\hline Huachuca Canyon gaging station & 9471310 & 558181 & 3487180 & $\mathrm{~W}$ & 0.0 & 3 & 650578 & 49232 & 87825 \\
\hline Ramsey Canyon gaging station & 9470500 & 565932 & 3479375 & $\mathrm{~W}$ & 0.0 & 3 & 699810 & 0 & 87825 \\
\hline Banning Creek gaging station & 9470500 & 594450 & 3485829 & $\mathrm{E}$ & 0.0 & 3 & 235170 & 99960 & 452505 \\
\hline
\end{tabular}




\begin{tabular}{|c|c|c|c|c|c|c|c|c|c|c|c|c|}
\hline \multirow[b]{2}{*}{ Temperature logger location } & \multicolumn{4}{|c|}{$\begin{array}{l}\text { December 1, 2000, to May 31, } 2001 \\
\text { (2000-2001 nonmonsoon) } \\
\text { Total time (minutes): } 262065\end{array}$} & \multicolumn{4}{|c|}{$\begin{array}{l}\text { June 1, 2001, to September 19, } 2001 \\
\text { (2001 monsoon) } \\
\text { Total time (minutes): } 159825\end{array}$} & \multicolumn{4}{|c|}{$\begin{array}{c}\text { September 20, 2001, to May 31, } 2002 \\
\text { (2001-2002 nonmonsoon) } \\
\text { Total time (minutes): } 365745\end{array}$} \\
\hline & $\begin{array}{c}\text { Number of } \\
\text { flows }\end{array}$ & $\begin{array}{c}\text { Flow } \\
\text { duration } \\
\text { (minutes) }\end{array}$ & $\begin{array}{l}\text { Bad or } \\
\text { missing } \\
\text { data } \\
\text { (minutes) }\end{array}$ & $\begin{array}{l}\text { No-flow } \\
\text { duration } \\
\text { (minutes) }\end{array}$ & $\begin{array}{l}\text { Number of } \\
\text { flows }\end{array}$ & $\begin{array}{l}\text { Flow } \\
\text { duration } \\
\text { (minutes) }\end{array}$ & $\begin{array}{l}\text { Bad or } \\
\text { missing } \\
\text { data } \\
\text { (minutes) }\end{array}$ & $\begin{array}{l}\text { No-flow } \\
\text { duration } \\
\text { (minutes) }\end{array}$ & $\begin{array}{c}\text { Number of } \\
\text { flows }\end{array}$ & $\begin{array}{l}\text { Flow } \\
\text { duration } \\
\text { (minutes) }\end{array}$ & $\begin{array}{l}\text { Bad or } \\
\text { missing } \\
\text { data } \\
\text { (minutes) }\end{array}$ & $\begin{array}{l}\text { No-flow } \\
\text { duration } \\
\text { (minutes) }\end{array}$ \\
\hline Ash at Coronado Mem. Rd. & 2 & 90 & 0 & 261975 & 2 & 1035 & 0 & 158790 & 0 & 0 & 0 & 365745 \\
\hline Ash at Stone Ridge & 0 & 0 & 262065 & 0 & 0 & 0 & 159825 & 0 & 0 & 0 & 365745 & 0 \\
\hline Brown south of Sttate Route 92 & 0 & 0 & 262065 & 0 & 4 & 975 & 98235 & 60615 & 0 & 0 & 354720 & 11025 \\
\hline Brown at Coronado Memorial Road & 1 & 600 & 0 & 261465 & 1 & 30 & 49890 & 109905 & 0 & 0 & 313425 & 52320 \\
\hline Carr at Moson Rd. & 0 & 0 & 146851 & 115214 & 5 & 300 & 26444 & 133081 & 1 & 825 & 0 & 364920 \\
\hline Carr at State Route 92 & 0 & 0 & 262065 & 0 & 3 & 1665 & 0 & 158160 & 1 & 135 & 0 & 365610 \\
\hline Coyote at Dake Road & 0 & 0 & 0 & 262065 & 8 & 2760 & 0 & 157065 & 0 & 0 & 0 & 365745 \\
\hline Coyote at Moson Road & 0 & 0 & 0 & 262065 & 1 & 15 & 106995 & 52815 & 0 & 0 & 15585 & 350160 \\
\hline Coyote at State Route 92 & 0 & 0 & 262065 & 0 & 0 & 0 & 159825 & 0 & 0 & 0 & 365745 & 0 \\
\hline Garden at fort perimeter & 0 & 0 & 247090 & 14975 & 5 & 195 & 10865 & 148765 & 0 & 0 & 0 & 365745 \\
\hline Garden at Moson Rd. & 0 & 0 & 0 & 262065 & 6 & 300 & 0 & 159525 & 0 & 0 & 0 & 365745 \\
\hline Garden at State Route 92 & 1 & 900 & 0 & 261165 & 8 & 3195 & 0 & 156630 & 2 & 810 & 0 & 364935 \\
\hline Garden at the SPRNCA & 1 & 180 & 0 & 261885 & 6 & 495 & 0 & 159330 & 0 & 0 & 0 & 365745 \\
\hline Graveyard: middle arm & 1 & 30 & 0 & 262035 & 3 & 315 & 0 & 159510 & 0 & 0 & 0 & 365745 \\
\hline Graveyard: north arm & 0 & 0 & 23490 & 238575 & 0 & 0 & 159825 & 0 & 0 & 0 & 33090 & 332655 \\
\hline Graveyard: south arm & 0 & 0 & 0 & 262065 & 0 & 0 & 107190 & 52635 & 0 & 0 & 327240 & 38505 \\
\hline Huachuca at Backer ${ }^{l}$ & $N A$ & $N A$ & 0 & 262065 & 6 & 600 & 103125 & 56100 & 9 & 13710 & 0 & 352035 \\
\hline Huachuca at GS Field & 1 & 600 & 0 & 261465 & 9 & 330 & 0 & 159495 & 0 & 0 & 0 & 365745 \\
\hline Hunter at Hereford Rd. & 2 & 300 & 0 & 261765 & 10 & 1905 & 0 & 157920 & 0 & 0 & 0 & 365745 \\
\hline Hunter at State Route 92 & 0 & 0 & 0 & 262065 & 1 & 285 & 0 & 159540 & 0 & 0 & 0 & 365745 \\
\hline Miller at Moson Rd. & 1 & 360 & 0 & 261705 & 5 & 750 & 0 & 159075 & 0 & 0 & 0 & 365745 \\
\hline Miller at State Route 92 & 0 & 0 & 188475 & 73590 & 3 & 990 & 7733 & 151102 & 0 & 0 & 0 & 365745 \\
\hline Miller at the SPRNCA & 0 & 0 & 0 & 262065 & 3 & 450 & 0 & 159375 & 1 & 150 & 0 & 365595 \\
\hline Ramsey at La Donna Rd. & 3 & 1080 & 0 & 260985 & 6 & 1605 & 0 & 158220 & 1 & 360 & 0 & 365385 \\
\hline Ramsey at Ramsey Canyon Rd. & 0 & 0 & 252495 & 9570 & 3 & 735 & 0 & 159090 & 0 & 0 & 0 & 365745 \\
\hline Ramsey at State Route 92 & 0 & 0 & 252614 & 9451 & 8 & 1200 & 0 & 158625 & 0 & 0 & 0 & 365745 \\
\hline Ramsey at the SPRNCA & 0 & 0 & 0 & 262065 & 4 & 1260 & 0 & 158565 & 1 & 120 & 0 & 365625 \\
\hline Soldier at Irwin Rd. & 0 & 0 & 262065 & 0 & 0 & 0 & 159810 & 15 & 0 & 0 & 261300 & 104445 \\
\hline Soldier at State Route 90 Bypass & 0 & 0 & 214530 & 47535 & 3 & 165 & 28035 & 131625 & 0 & 0 & 0 & 365745 \\
\hline Stump at Deer Canyon Tr. & 0 & 0 & 146852 & 115213 & 2 & 225 & 7783 & 151817 & 0 & 0 & 0 & 365745 \\
\hline Stump at State Route 92 & 0 & 0 & 262065 & 0 & 5 & 2490 & 69075 & 88260 & 1 & 150 & 0 & 365595 \\
\hline Wash 1: middle arm & 0 & 0 & 0 & 262065 & 3 & 330 & 106545 & 52950 & 0 & 0 & 304485 & 61260 \\
\hline Wash 1: north arm & 0 & 0 & 23385 & 238680 & 0 & 0 & 159825 & 0 & 0 & 0 & 364305 & 1440 \\
\hline
\end{tabular}


Temperature-logger data, by location and period-Continued

\begin{tabular}{|c|c|c|c|c|c|c|c|c|c|c|c|c|}
\hline \multirow[b]{2}{*}{ Temperature logger location } & \multicolumn{4}{|c|}{$\begin{array}{c}\text { December 1, 2000, to May 31, } 2001 \\
\text { (2000-2001 nonmonsoon) } \\
\text { Total time (minutes): } 262065\end{array}$} & \multicolumn{4}{|c|}{$\begin{array}{c}\text { June 1, 2001, to September 19, } 2001 \\
\text { (2001 monsoon) } \\
\text { Total time (minutes): } 159825\end{array}$} & \multicolumn{4}{|c|}{$\begin{array}{c}\text { September 20, 2001, to May 31, } 2002 \\
\text { (2001-2002 nonmonsoon) } \\
\text { Total time (minutes): } 365745\end{array}$} \\
\hline & $\begin{array}{c}\text { Number of } \\
\text { flows }\end{array}$ & $\begin{array}{c}\text { Flow } \\
\text { duration } \\
\text { (minutes) }\end{array}$ & $\begin{array}{l}\text { Bad or } \\
\text { missing } \\
\text { data } \\
\text { (minutes) }\end{array}$ & $\begin{array}{l}\text { No-flow } \\
\text { duration } \\
\text { (minutes) }\end{array}$ & $\begin{array}{c}\text { Number of } \\
\text { flows }\end{array}$ & $\begin{array}{c}\text { Flow } \\
\text { duration } \\
\text { (minutes) }\end{array}$ & $\begin{array}{l}\text { Bad or } \\
\text { missing } \\
\text { data } \\
\text { (minutes) }\end{array}$ & $\begin{array}{l}\text { No-flow } \\
\text { duration } \\
\text { (minutes) }\end{array}$ & $\begin{array}{l}\text { Number of } \\
\text { flows }\end{array}$ & $\begin{array}{c}\text { Flow } \\
\text { duration } \\
\text { (minutes) }\end{array}$ & $\begin{array}{l}\text { Bad or } \\
\text { missing } \\
\text { data } \\
\text { (minutes) }\end{array}$ & $\begin{array}{l}\text { No-flow } \\
\text { duration } \\
\text { (minutes) }\end{array}$ \\
\hline Wash 1: south arm & 0 & 0 & 23415 & 238650 & 0 & 0 & 159825 & 0 & 0 & 0 & 33000 & 332745 \\
\hline Woodcutters at 7 th St. & 1 & 30 & 0 & 262035 & 16 & 7260 & 0 & 152565 & 0 & 0 & 0 & 365745 \\
\hline Woodcutters at Moson Rd. (ext.) & 1 & 180 & 0 & 261885 & 7 & 1920 & 0 & 157905 & 0 & 0 & 0 & 365745 \\
\hline Woodcutters at State Route 90 Bypass & 1 & 780 & 0 & 261285 & 6 & 1200 & 24510 & 134115 & 1 & 45 & 0 & 365700 \\
\hline Banning at Misty Ray Rd. & 0 & 0 & 262065 & 0 & 2 & 750 & 0 & 159075 & 1 & 240 & 0 & 365610 \\
\hline Banning at State Route 80 & NA & NA & 115170 & 146895 & 2 & 165 & 0 & 159660 & 0 & 0 & 0 & 365745 \\
\hline Government at Cox Ranch & 0 & 0 & 0 & 262065 & 3 & 225 & 0 & 159600 & 0 & 0 & 0 & 365745 \\
\hline Government at High Knoll Rd. & 1 & 60 & 0 & 262005 & 8 & 5250 & 0 & 154575 & 0 & 0 & 0 & 365745 \\
\hline Government at State Route 80 & 1 & 90 & 0 & 261975 & 3 & 405 & 0 & 159420 & 0 & 0 & 0 & 365745 \\
\hline Greenbush at Fox Hollow Rd. & 0 & 0 & 262065 & 0 & 4 & 2400 & 36720 & 120705 & 0 & 0 & 0 & 365745 \\
\hline Greenbush at Naco Highway & 2 & 510 & 0 & 261555 & 4 & 0 & 130425 & 29400 & 0 & 0 & 324870 & 40875 \\
\hline Greenbush at railroad tracks & 0 & 0 & 262065 & 0 & 0 & 0 & 36885 & 122940 & 0 & 0 & 0 & 365745 \\
\hline Greenbush east of Ladds house & 0 & 0 & 262065 & 0 & 11 & 3450 & 36795 & 119580 & 0 & 0 & 0 & 365745 \\
\hline Greenbush tributary at Foudy Rd. & 0 & 0 & 252645 & 9420 & 6 & 1845 & 0 & 157980 & 0 & 0 & 225195 & 140550 \\
\hline Greenbush tributary: Sand Wash & 0 & 0 & 262065 & 0 & 3 & 1035 & 36825 & 121965 & 0 & 0 & 0 & 365745 \\
\hline Greenbush gaging station & 0 & 0 & 0 & 262065 & 1 & 15 & 0 & 159810 & ${ }^{2} 0$ & $0^{2}$ & $0^{2}$ & 365730 \\
\hline Spring at Foudy Rd. & 0 & 0 & 0 & 262065 & 6 & 420 & 0 & 159405 & 0 & 0 & 0 & 365745 \\
\hline Spring at Hereford Rd. & 0 & 0 & 0 & 262065 & 1 & 900 & 0 & 158925 & 0 & 0 & 0 & 365745 \\
\hline Wash 20 at High Knoll Rd: north & 1 & 270 & 49695 & 212100 & 1 & 135 & 109755 & 49935 & 0 & 0 & 200805 & 164940 \\
\hline Wash 20 at High Knoll Rd: south & 3 & 420 & 0 & 261645 & 3 & 1860 & 0 & 157965 & 0 & 0 & 0 & 365745 \\
\hline Wash 20 at State Route 80 & 2 & 1380 & 0 & 260685 & 2 & 90 & 91320 & 68415 & 0 & 0 & 199770 & 165975 \\
\hline Walnut Gulch flume 1 & 1 & 45 & 0 & 262020 & 4 & 570 & 0 & 159255 & 0 & 0 & 0 & 365745 \\
\hline Walnut Gulch flume 11 & 2 & 7232 & 0 & 254833 & 4 & 246 & 0 & 159579 & 0 & 0 & 0 & 365745 \\
\hline Walnut Gulch flume 6 & 0 & 0 & 0 & 262065 & 0 & 0 & 0 & 159825 & 0 & 0 & 0 & 365745 \\
\hline Lower Babo gaging station & 1 & 262065 & 0 & 0 & 1 & 159825 & 0 & 0 & 1 & 277920 & 0 & 87825 \\
\hline Upper Babo gaging station & 1 & 262065 & 0 & 0 & 1 & 159825 & 0 & 0 & 1 & 277920 & 0 & 87825 \\
\hline Garden Canyon gaging station & 1 & 262065 & 0 & 0 & 1 & 159825 & 0 & 0 & 1 & 277920 & 0 & 87825 \\
\hline Huachuca Canyon gaging station & 1 & 257235 & 4830 & 0 & 1 & 115423 & 44402 & 0 & 1 & 277920 & 0 & 87825 \\
\hline Ramsey Canyon gaging station & 1 & 262065 & 0 & 0 & 1 & 159825 & 0 & 0 & 1 & 277920 & 0 & 87825 \\
\hline Banning Creek gaging station & 1 & 134100 & 99960 & 28005 & 1 & 95715 & 0 & 64110 & 1 & 5355 & 0 & 360390 \\
\hline
\end{tabular}

${ }^{1}$ Construction at the Huachuca Canyon at Backer Road site caused anomalous temperature data (human caused flow); no data from this site were used for analysis.

${ }^{2}$ On the basis of weather records, a 15-min flow recorded at Greenbush Draw gaging station on March 1, 2002, is considered a false positive. 
Manuscript approved for publication, August 25, 2005.

Prepared by the Reports Section, U.S. Geological Survey, Tucson, Arizona.

USGS Publishing staff

Steve A. Longsworth, Supervisory Hydrologist

Tracey L. Suzuki, Technical Editor

John Callahan, Illustrator

Sid Alwin, Illustrator

Aaron Fortner, Publications Assistant

For more information concerning the research in this report, contact the Arizona Water Science Center Director,

U.S. Geological Survey, 520 N. Park Ave., Suite 221

Tucson, AZ 85719

http://az.water.usgs.gov 


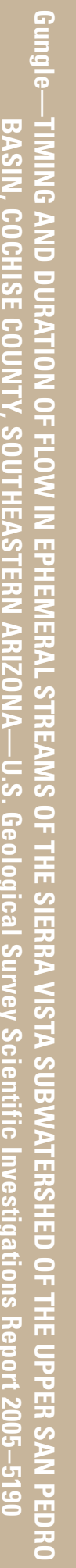

